Western Kentucky University

TopSCHOLAR ${ }^{\circledast}$

Masters Theses \& Specialist Projects

Graduate School

Summer 2018

\title{
Using Mobile Eye-Tracking to Inform the Development of Mass Tourism in Iceland Towards the Principles of Ecotourism
}

James Tyler Graham

Follow this and additional works at: https://digitalcommons.wku.edu/theses

Part of the Communication Technology and New Media Commons, Environmental Education Commons, Environmental Health and Protection Commons, Geography Commons, and the Tourism Commons

This Thesis is brought to you for free and open access by TopSCHOLAR ${ }^{\circledR}$. It has been accepted for inclusion in Masters Theses \& Specialist Projects by an authorized administrator of TopSCHOLAR. For more information, please contact topscholar@wku.edu. 


\title{
USING MOBILE EYE-TRACKING TO INFORM THE DEVELOPMENT OF MASS TOURISM IN ICELAND TOWARDS THE PRINCIPLES OF ECOTOURISM
}

\author{
A Thesis \\ Presented to \\ The Faculty of the Department of Geography and Geology \\ Western Kentucky University \\ Bowling Green, Kentucky
}

In Partial Fulfillment

Of the Requirements for the Degree

Master of Science

By

James Graham

August 2018 
USING MOBILE EYE-TRACKING TO INFORM THE DEVELOPMENT OF MASS TOURISM IN ICELAND TOWARDS THE PRINCIPLES OF ECOTOURISM

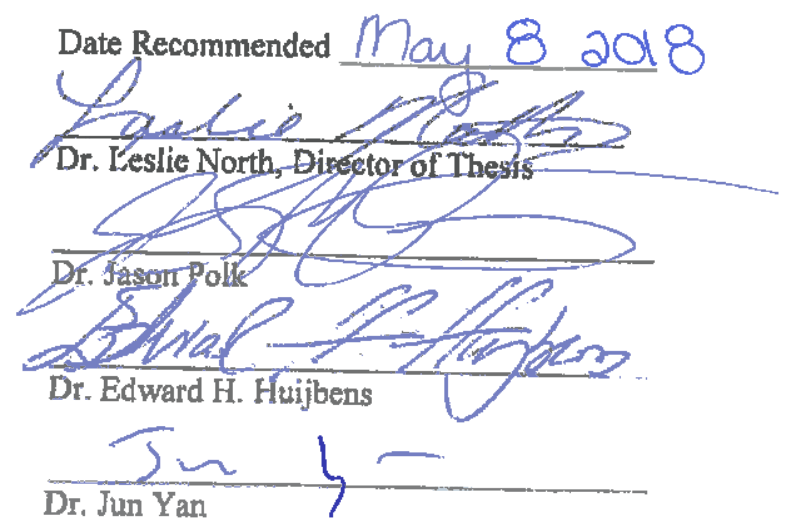

$\frac{\text { Cheyl 8. Qars } 7 / 1 / 18}{\text { Dean, Graduate Studies and Research }}$ 


\section{CONTENTS}

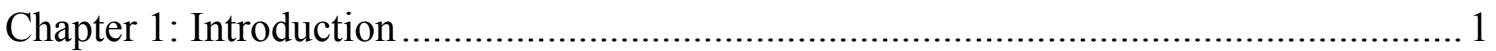

1.1 Research Purpose and Questions .......................................................... 3

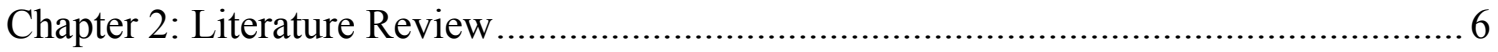

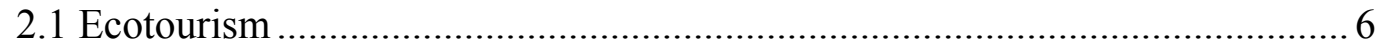

2.1.1 Implications of Ecotourism ................................................ 8

2.2 Ecotourism in the Arctic ................................................................... 10

2.2.1 Ecotourism in Iceland ............................................................ 11

2.3 Ecotourism as a Platform for Informal Learning ...................................... 15

2.3.2 Interpretive Signage as a Management Tool in Ecotourism........... 16

2.4 Eye-Tracking and Ecotourism ................................................................ 20

2.4.1 Eye-Tracking in Ecotourism ................................................. 21

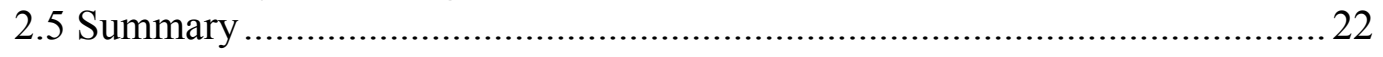

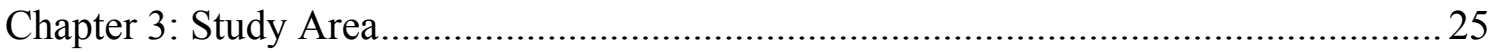

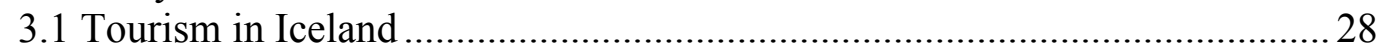

3.2 Areas of Interest Within Iceland .......................................................... 30

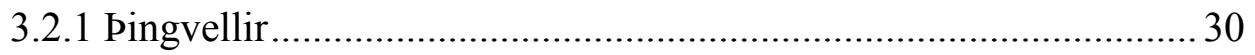

3.2.2 Sólheimajökull ........................................................... 33

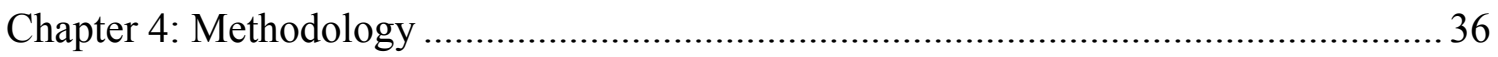

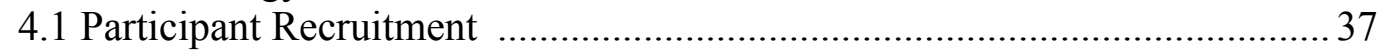

4.2 Mobile Eye-tracking Trials ............................................................. 38

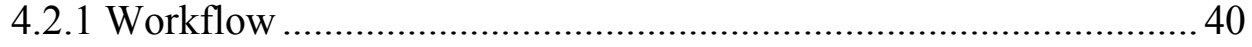

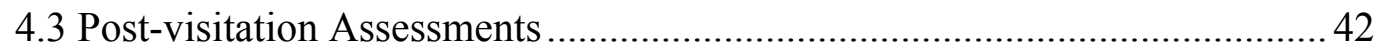

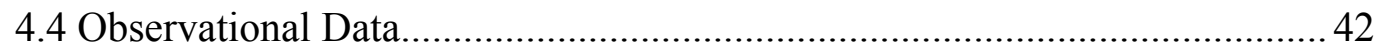

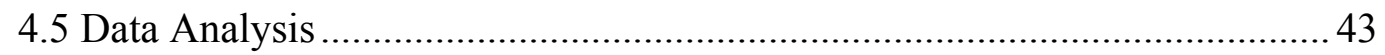

4.5.1 Visitor Footpath Analysis .................................................... 43

4.5.2 Post-visitation Assessments ...................................................... 43

4.5.3 Eye-tracking Trials......................................................... 44

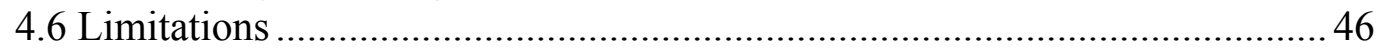

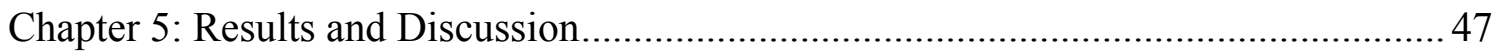

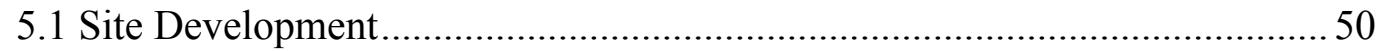

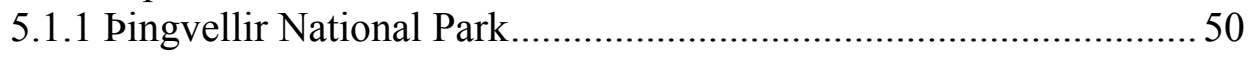

5.1.2 Sólheimajökull ...................................................................59

5.1.3 Combining GPS and Eye-Tracking Data for Site Development .... 64

5.2 Tourist Expectation and Behavior ...................................................... 76

5.2.1 Visitor Expectations and Experiences ..................................... 76

5.2.2 Visitor Behavior .............................................................. 90

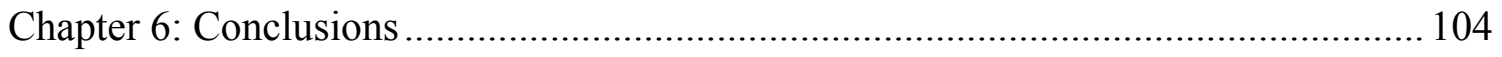


6.1 Recommendations for Future Development .......................................... 108

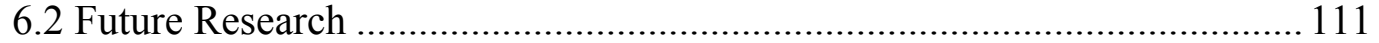

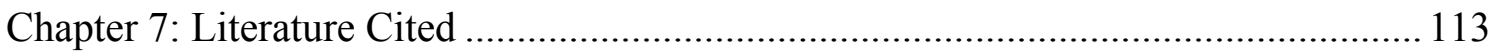




\section{LIST OF FIGURES}

Figure 2.1 Sectoral share of total export revenues in Iceland ..................................... 12

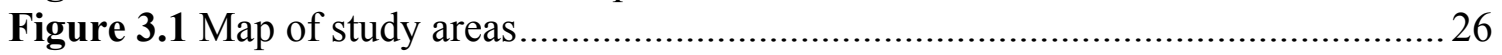

Figure 3.2 Lögberg at Pingvellir National Park............................................................. 31

Figure 3.3 Management sign vs. educational sign at Pingvellir National Park ............. 32

Figure 3.4 Sólheimajökull tourism destination ………….............................................. 34

Figure 4.1 Flow chart of data collection and analysis...................................................36

Figure 4.2 Tobii Pro Glasses 2 Mobile Eye-tracking Unit ........................................... 39

Figure 4.3 File structure for Tobii Controller interface ………………….....................4 41

Figure 5.1 Distribution of signs and trail design at Pingvellir National Park ................52

Figure 5.2 Participant 2 distinguishes defined trail from restricted area .......................53

Figure 5.3 Boardwalk at Pingvellir National Park ....................................................53

Figure 5.4 Attention path of Participant 2 walking on trail at Pingvellir (heat map) ..... 55

Figure 5.5 Attention path of Participant 2 walking on trail at Pingvellir (gaze plot) .....56

Figure 5.6 Attention path of Participant 25 walking Sólheimajökull trail (heat map) ...57

Figure 5.7 Attention path of Participant 25 walking Sólheimajökull trail (gaze plot)....58

Figure 5.8 Visitor deviating from trail at Sólheimajökull ............................................5 59

Figure 5.9 Sign distribution and trail design at Sólheimajökull .....................................62 62

Figure 5.10 Participant 26 misinterprets third sign at Sólheimajökull ............................63

Figure 5.11 Location of significant GPS error at Pingvellir (photo) .............................66

Figure 5.12 Location of significant GPS error at Pingvellir (map) ................................67

Figure 5.13 Visitor hot spots at Sólheimajökull ………............................................. 70

Figure 5.14 Visitor hot spots at Pingvellir .............................................................. 71

Figure 5.15 Deviation by Participant 14 at Pingvellir ................................................. 74

Figure 5.16 Example location of visitor interest at Pingvellir ....................................... 75

Figure 5.17 Distribution of Likert scale responses ...................................................... 78

Figure 5.18 Visitor attention while observing a sign at Pingvellir ................................8 85

Figure 5.19 Participant attempts to navigate Pingvellir using directional sign ..............87

Figure 5.20 Participant 24 reads interpretive sign at Sólheimajökull ............................. 89

Figure 5.21 Participant 17 gestures group away from signs towards trail ....................90

Figure 5.22 Tour group arriving at Pingvellir............................................................... 95

Figure 5.23 Participant 13 points to trail expectation at Pingvellir ............................... 96

Figure 5.24 Management signs at Pingvellir ............................................................... 97

Figure 5.25 Sign at trail entrance and ending at Sólheimajökull .................................... 98

Figure 5.26 Sign at glacial terminus at Sólheimajökull ................................................ 99

Figure 5.27 Herd mentality documented using eye-tracking heat map ........................ 101 


\section{LIST OF TABLES}

Table 2.1 Frequency of themes in ecotourism definitions amidst current literature .8

Table 5.1 Demographic summary of eye-tracking participants ................................. 48

Table 5.2 Demographic summary of survey respondents ........................................ 49

Table 5.3 Breakdown of post-assessment responses (Sólheimajökull)......................... 79

Table 5.4 Breakdown of post-assessment responses (Pingvellir) ................................. 80 


\section{LIST OF APPENDICES}

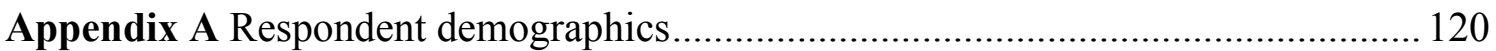

Appendix B Eye-Tracking participant demographics............................................. 122

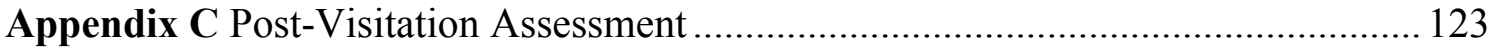

Appendix D Pingvellir themes identified in eye-tracking trials ................................ 124

Appendix E Sólheimajökull themes identified in eye-tracking trials ......................... 125 


\section{USING MOBILE EYE-TRACKING TO INFORM THE DEVELOPMENT OF MASS TOURISM IN ICELAND TOWARDS THE PRINCIPLES OF ECOTOURISM}

James Graham

August 2018

126 Pages

Directed by: Dr. Leslie North, Dr. Jason Polk, Dr. Edward Huijbens, Dr. Jun Yan

Department of Geography and Geology Western Kentucky University

Since the late $20^{\text {th }}$ century, nature-based tourism, an alternative to mass tourism with a focus on natural environments, has steadily grown in popularity. Nature-based tourism areas are considered a platform for informal education and exemplify principles of environmental stewardship and conservation. Iceland, an island nation in the North Atlantic, is one area of the world that has seen dramatic growth in its nature-based tourism industry in recent years; tourists are drawn to Iceland in numbers five times the total population of the Country. The pressures of economic development have resulted in the continued promotion of Icelandic tourism, and, subsequently, the rapid, sometimes detrimental, development of tourist destinations. This study used a triangulated mixed methods approach including post-visitation assessments, mobile eye-tracking (MET), GPS footpath collection, and observational analysis to assess visitor experience and behavior in two popular Icelandic tourist destinations: Sólheimajökull and Pingvellir. Through the use of MET, a greater understanding of visitor behavior was developed in these areas. Results suggest that the infrastructure development which has occurred at Pingvellir is effective at managing tourist behavior; however, the less developed and more authentic environment of Sólheimajökull appeals more to visitor expectations of Icelandic tourism. Observing the strengths and weaknesses of the study sites revealed ways to guide the future development of the sites in ways that promote both education 
and conservation. Furthermore, the critical evaluation of the original methodology developed for this study also presents a technique by which the development of other nature-based tourism destinations can be assessed. 


\section{Chapter 1: Introduction}

In recent decades, trends in tourism have become more diverse, ranging from standard mass-tourism practices to more sustainable alternative forms. Alternative tourism, as a label for a wide range of divergent practices, is characterized as development that promotes conservation of host environments and cultures (Hetzer 1965; Fennel 2003); one subsection of alternative tourism, ecotourism, is defined by travel to natural environments (Thompson 1995). Commonly stated principles of ecotourism are education and the protection of natural areas (Fennel 2003). To promote education and discourage environmentally-degrading behavior in natural environments, information is often disseminated to tourists at tourism sites through the use of interpretive signage (Orams 1996). The use of trails and the designation of restricted areas are also common practice, yet few studies have attempted to evaluate the use of interpretive signs as an educational medium and management method in tourist areas (Kiefer et al. 2012). Furthermore, limited studies have documented how signs, trails, and restricted areas can be used in conjunction with one another to manage tourist behavior, while also promoting positive tourist experience.

Iceland, an island nation in the North Atlantic Ocean, is characterized by sprawling lava fields, considerable glaciation, an abundance of waterfalls, and massive fjords (Karlsson et al. 2018). The desire to see these natural environments has consistently been rated as the top motivation for visiting Iceland in a series of surveys distributed to departing international tourists (Óladóttir 2012; 2013; 2014; 2015). In recent years, the number of inbound tourist to Iceland has tripled (Óladóttir 2016); this trend has resulted in the need for rapid development of Iceland's tourist infrastructure, 
from hotels to nature-based site development. The influx of tourists to Iceland has placed increasing pressure on the Country's natural environments. The Environmental Protection Agency of Iceland has suggested that the most vulnerable natural areas in Iceland are also among the most popularly visited tourism destinations in the Country (Uhmverfisstofunn 2017a); thus, if development does not occur in a way that promotes conservation of Icelandic nature many of these environments will face degradation. The environment, climate, geology, culture, and infrastructure of Iceland make the location an exceptional platform for informal education and an interesting case study in the development of ecotourism destinations. Iceland is home to one of the most drastic and diverse landscapes, despite its relatively small size of approximately $103,000 \mathrm{~km}^{2}$ (CIA 2016). In Iceland, tourists can visit black sand beaches, volcanoes, and glaciers, often within minutes of each other; furthermore, the harsh environment, seclusion, and limited resources of Iceland have shaped a resilient and unique culture. All of the things Iceland has to offer a visitor can serve to foster both an appreciation and understanding for the natural environment if visitor interaction with the environment is guided through the use of interpretive signage, infrastructure, and experiential learning experiences.

Eye-tracking is a method of study that analyzes eye movement to understand the common influences of attention and comprehension (Tanenhaus and Spivey-Knowlton 1996). Past applications of eye tracking technology have been in the educational and marketing fields; however, the technology is beginning to be used in increasingly diverse environments. Mobile eye-tracking technology is a developing technology that uses sensors to track the movement of a retina to study an individual's cognitive processes. Eye-tracking data are used as a proxy for assessing attention and determining 
common areas of interest in an environment or on a graphic (Duchowski 2007). More recently, the use of eye-tracking as a mobile technology has be helpful in understanding human-environmental interaction (Keifer et al. 2012); yet, there is a lack in the application of mobile eye-tracking technology in the ecotourism sector, specifically. Use of mobile eye-tracking technology in the tourism sector could help to provide great insights into visitor's process of perception and response to various stimuli within an environment; this can serve to guide the future development of ecotourism destinations.

\subsection{Research Purpose and Questions}

The purpose of this study was to assess the viability of mobile eye-tracking as a tool for guiding the informed development of tourism destinations. The following research questions were answered:

- In what ways can mobile eye-tracking technology be used to guide the development of mass tourism destinations towards the principles of ecotourism?

- In what ways can mobile eye-tracking technology be used to better understand and influence visitor experience at nature-based tourism destinations?

- In what ways can interpretive signage prevent environmentally-degrading behavior at nature-based tourism destinations?

- In what ways can tracking a visitor's movement through natural areas add interpretative meaning to mobile eye-tracking data?

To answer the aforementioned research questions, this study used mobile eyetracking technology, coupled with post-visitation assessments, GPS footpath data, and observational analysis, to determine the ways that tourists experience, learn, and interact 
with the natural environments of Icelandic nature-based tourism destinations.

Furthermore, the trends in attitude, understanding, and behavior inspired by the presence of signage in natural areas was explored. The mixed method approach utilized in this study was designed to assess visitor experience and the development of nature-based tourism destinations in Iceland, as well as to determine whether or not visitor behavior aligns with the principles of ecotourism. Collection of GPS data related to participant movement was effective at identifying specific areas of interest within both study sites. The addition of mobile eye-tracking made it possible to identify what influenced visitor behavior within these specific areas of interest; additionally, the mobile eye-tracking technology produced useful data to recognize the ways in which participants engage with and interpret signs located throughout both study sites.

In answering the aforementioned research questions, this study draws conclusions about the current development of Icelandic tourism destinations and whether or not the development has occurred in such a way that promotes education and conservation. A recent study by Óladóttir (2016) that surveyed tourists in Iceland found that $75.7 \%$ of respondents believed tourist pressure on Icelandic nature was too high. The same study showed that education was commonly stated as a solution to environmental degradation. Ecotourism destinations should be considered a platform for informal education and should aim to promote environmental stewardship and conservation through interpretive programs and infrastructure. This study examined current development at two Icelandic nature-based tourism destinations, Sólheimajökull and Pingvellir, through analysis of visitor experience, behavior, and perception of the experience. Furthermore, this study identified the ways in which development can 
effectively guide visitor behavior and promote education. The findings of this study are useful to inform the future development of Icelandic tourist areas towards the principles of ecotourism. Finally, through this study, an original methodology for assessing visitor experience in nature-based tourism destinations that may be used in guiding future development towards the principles of ecotourism was validated. 


\section{Chapter 2: Literature Review}

\subsection{Ecotourism}

The concept of ecotourism is still in the process of being defined; the term itself not being coined until the 1980s. Considerable variation exists within the current literature defining ecotourism; yet, ecotourism can be most simply defined as a form of alternative tourism with emphasis on the Earth's natural environments (Fennell 2003). Thompson (1995) suggests that the term ecotourism was first coined by CeballosLascuráin in the 1980s as travel to natural environments for the purpose of admiring, studying, and enjoying the scenery, wildlife, and culture. Since its inception, ecotourism has come to align more closely with the principles discussed by Krippendorff (1982). In his study, Krippendorff (1982) recognized the potential environmental and social consequences brought on by the economically-driven mass tourism industry. This shift in understanding inspired a push for alternative forms of tourism that promoted not only economic development, but also aimed to preserve and protect the destination environment and address the needs and concerns of local populations in those environments (Fennell 2003).

In the 1960 s, the consumer-driven mass tourism industry received heavy criticism for the economic exploitation and cultural pollution of host communities (Krippendorff 1982; Cohen 1987). These criticisms sparked a movement towards alternative forms of tourism that aim to promote more sustainable practices. This is not to say that mass tourism and ecotourism are mutually exclusive; Weaver (2001) presents a somewhat contentious concept of mass ecotourism. Weaver (2001) argues for a distinction between 'hard' ecotourism and 'soft' ecotourism, with the former being 
smaller-scale tourism operations where improvement of sustainability initiatives and conservation are the goal of the tourist. The latter, 'soft' ecotourism, are nature-based tourism practices characterized by larger number of visitors with increased expectation of amenities; however, these tourists still recognize the importance of conservation, but lack the desire to improve sustainable initiatives in an area. Further, a common misconception in the discussion of tourism is that scale is correlated with impacts; thus, the term mass tourism has developed a negative connotation. Weaver (2001) points to the fact that conservation is associated with a decrease in visitation, when in reality the focus should be placed on the development of appropriate management strategies.

While ecotourism is in large part defined by place, it is almost equally associated with a set of principles outlined in an article by Hetzer (1965) which suggests a framework for sustainable and ethical tourism that encourages minimized environmental degradation, consideration of host cultures, economic benefit for the host community, and recreational enjoyment by participants. Ecotourism, as it is most commonly defined, is nearly synonymous with Hetzer's (1965) concept of sustainable tourism. A comparative review of literature by Fennell (2003) showed that conservation and the consideration of local populations were both commonly cited as principles in defining ecotourism. As shown in Table 2.1, several themes exist in the literature published about ecotourism; however, a definitive definition for ecotourism has not yet been agreed upon by the scholarly community due to the site-specific nature of tourism activities and the broad scope of tourism with varying degrees of environmental foci. To better define ecotourism, it is beneficial to understand the potential implications, both positive and negative, associated with the industry. 
Table 2.1: Frequency of themes in ecotourism definitions amidst current literature. Each column represents the characteristics of an ecotourism definition in a single publication. Modified from Fennell (2003, 16).

\begin{tabular}{|c|c|c|c|c|c|c|c|c|c|c|c|c|c|c|c|}
\hline & \multicolumn{15}{|c|}{ Occurrence in definitions } \\
\hline Main principles of definition & 1 & 2 & 3 & 4 & 5 & 6 & 7 & 8 & 9 & 10 & 11 & 12 & 13 & 14 & 15 \\
\hline Interest in nature & $\mathrm{X}$ & $\mathrm{X}$ & & & $\mathrm{X}$ & $\mathrm{X}$ & $\mathrm{X}$ & $\mathrm{X}$ & & $\mathrm{X}$ & $\mathrm{X}$ & & & $\mathrm{X}$ & $\mathrm{X}$ \\
\hline Contributes to conservation & & & $X$ & & $\mathrm{X}$ & $\mathrm{X}$ & $\mathrm{X}$ & $\mathrm{X}$ & $\mathrm{X}$ & $\mathrm{X}$ & & & $\mathrm{X}$ & $X$ & $\mathrm{X}$ \\
\hline Reliance on parks and protected areas & $X$ & & $\mathrm{X}$ & & $\mathrm{X}$ & $\mathrm{X}$ & & $\mathrm{X}$ & $\mathrm{X}$ & & & & $\mathrm{X}$ & $\mathrm{X}$ & $\mathrm{X}$ \\
\hline Benefits local people/long-term benefits & & & $\mathrm{X}$ & & $\mathrm{X}$ & $\mathrm{X}$ & $\mathrm{X}$ & & $\mathrm{X}$ & & & & $\mathrm{X}$ & $\mathrm{X}$ & $\mathrm{X}$ \\
\hline Education and study & $\mathrm{X}$ & $\mathrm{X}$ & $\mathrm{X}$ & & & $\mathrm{X}$ & & & & & $\mathrm{X}$ & & & $\mathrm{X}$ & $\mathrm{X}$ \\
\hline Low impact/non-consumptive & & & & & $\mathrm{X}$ & & & & & & & $\mathrm{X}$ & $\mathrm{X}$ & $\mathrm{X}$ & $\mathrm{X}$ \\
\hline Ethics/responsibility & & & & $\mathrm{X}$ & & & & & $\mathrm{X}$ & $\mathrm{X}$ & & & & & $\mathrm{X}$ \\
\hline Management & & & & & $\mathrm{X}$ & & & $\mathrm{X}$ & & & $\mathrm{X}$ & & & & $\mathrm{X}$ \\
\hline Sustainable & & & & & & & & $\mathrm{X}$ & & & $\mathrm{X}$ & & & $\mathrm{X}$ & $\mathrm{X}$ \\
\hline Enjoyment/Appreciation & $\mathrm{X}$ & & & & $\mathrm{X}$ & & & & & & & & & $\mathrm{X}$ & \\
\hline Culture & $\mathrm{X}$ & & & & $\mathrm{X}$ & & & & & & & & & $\mathrm{X}$ & \\
\hline Adventure & & $\mathrm{X}$ & & & & & & & & & & & & & \\
\hline Small scale & & & & & & & & & & & & $\mathrm{X}$ & & & $\mathrm{X}$ \\
\hline
\end{tabular}

\subsubsection{Implications of Ecotourism}

The implications associated with ecotourism range from economic to environmental in their focus. The desire to visit and experience natural places is the primary constituent driving the ecotourism industry (Hall and Page 2009); thus, many ecotourism destinations are developed around the environmental component. While some negative impacts arise from the increased presence of humans in natural areas, ecotourism should, in theory, be beneficial for the environment, as the primary goal is the conservation of natural places (Fennell 2003). In addition to environmental conservation, the economic opportunities allowed by ecotourism can be of great benefit to the host community. Economic development driven by ecotourism is favorable over heavy industry and other forms of economic development that have health and environmental implications (Tisdell 1996). A final benefit of ecotourism is that it exists as a platform for informal education (Walter 2009). Many ecotourism destinations gain popularity as a result of environmental or cultural significance. Fennell (2003) suggests 
that education and research are some of the most commonly stated principles of ecotourism. Provided a receptive audience, and given environmental and cultural significance of ecotourism destinations, management at these destinations should capitalize on the opportunity to educate their visitors. Through education, many of the negative environmental consequences of ecotourism can be mitigated and conservation mindsets can be instilled (Powell and Ham 2008).

At ecotourism destinations, negative impacts may occur when development transpires in a way that more closely mirrors mass tourism. One factor often overlooked in the development of ecotourism is the social implications for the host community, especially in rural environments (Boyne 2003). While there are economic benefits associated with ecotourism, Prosser (1994) discussed a potential boom and bust cycle in ecotourism where growth in popularity can lead to saturation. Additionally, over time, the popularity of a destination may fade and visitation declines. While investors and privatized tour operations can then move to new tourism destinations, host communities are often left to face the consequences of a collapsed economy (Wood 1998).

The cultural consequences of ecotourism must be considered for a host community. Hall et al. (2015) suggest that through continued growth in the ecotourism sector, the natural environment and culture of a location are continuously consumed. This idea is supported by Prosser (1994), who proposed that as tourism transitions from the unconventional adventurer to mass package tourists on standardized trips, the expectation of western amenities increases, which can blur the line between cultural identities. The purpose of ecotourism is to promote sustainable tourism practices that focus on the potential environmental, economic, and social implications of the industry 
(Fennell 2003). Brougham and Butler (1981) described that these three pillars should be framed within the context of their social impacts (Boyne 2003). One method by which these negative impacts can be mitigated is through improved methods of education (Gilbert 2003). In ecotourism destinations, education may be promoted through the use of interpretation, which includes guided tours and signage; thus, ecotourism destinations should focus on appropriate and affective interpretive programs in order to increase conservation outcomes (Powell and Ham 2008).

\subsection{Ecotourism in the Arctic}

Midtgard $(2003,102)$ showed that the opportunity to experience "authentic" places is a common motivator among tourists. Polar environments embody what remains of unspoiled wilderness environments (Sæpórsdóttir et al. 2011). In recent decades, there has been an influx of tourists to polar regions, which are characterized by harsh climates and geographic isolation; historically, these same qualities would have discouraged, or at least minimized, the travel to such places (Stewart et al. 2005). The growing trend in visitation to polar regions is likely a result of people believing these areas represent what remain of true wilderness areas; however, polar regions are also some of the most environmentally-vulnerable areas in the world.

Stewart et al. (2005) reviewed literature on polar tourism in an attempt to determine the most critical issues moving forward. Aside from the development of a sustainable industry that integrates the needs and knowledge of host populations, the issue of climate change was highlighted as a major concern. Additionally, a challenge in the development of tourism in many regions, including those in the Arctic, is how rural and secluded sites can be. The development of ecotourism destinations in rural areas 
presents a need for community involvement, infrastructural development, and effective management, particularly in the face of a changing climate.

The consequences of climate change on the tourism industry are both beneficial and detrimental. For example, Marsh and Staple (1995) described how a future reduction in sea ice could benefit the commercial cruise industry. In contrast, the disappearance or alteration of surface land features, such as glaciers and waterfalls, as well as wildlife may increase tourism activity in the short-term as a result of 'last chance tourism,' but the full alteration of the land features or disappearance of wildlife could result in a significant reduction in tourist visitation (Stewart et al. 2005; Johnston et al. 2013). One nation that has experienced a dramatic increase in tourist visitation and development over the past decade, in part due to 'last chance tourism,' is Iceland.

\subsubsection{Ecotourism in Iceland}

Iceland is a sub-Arctic island nation located in the North Atlantic Ocean. Iceland is roughly $103,000 \mathrm{~km}^{2}$ in size and has a total population of approximately 330,000 people. In 1997, 201,000 tourists visited Iceland; within a decade, tourist visitation doubled to nearly 450,000 (Jóhannesson et al. 2010). By 2017, the number of visitors to Iceland had reached 1,791,400 (Óladóttir 2017). Iceland's fjords, volcanic topography, and glaciers are just some of the many features that draw tourists to the region, in numbers many times Iceland's population, annually. In 2006, the tourism industry only accounted for 13\% of Iceland's economic revenue (Jóhannesson et al. 2010); an explosion in the tourism sector has contributed to tourism now replacing fisheries as the leading revenue generator (Figure 2.1). Given the success of tourism in Iceland following the almost total collapse of Iceland's banking sector in Fall 2008, a struggle 
exists between environmental conservation and the increased promotion of ecotourism in the region.

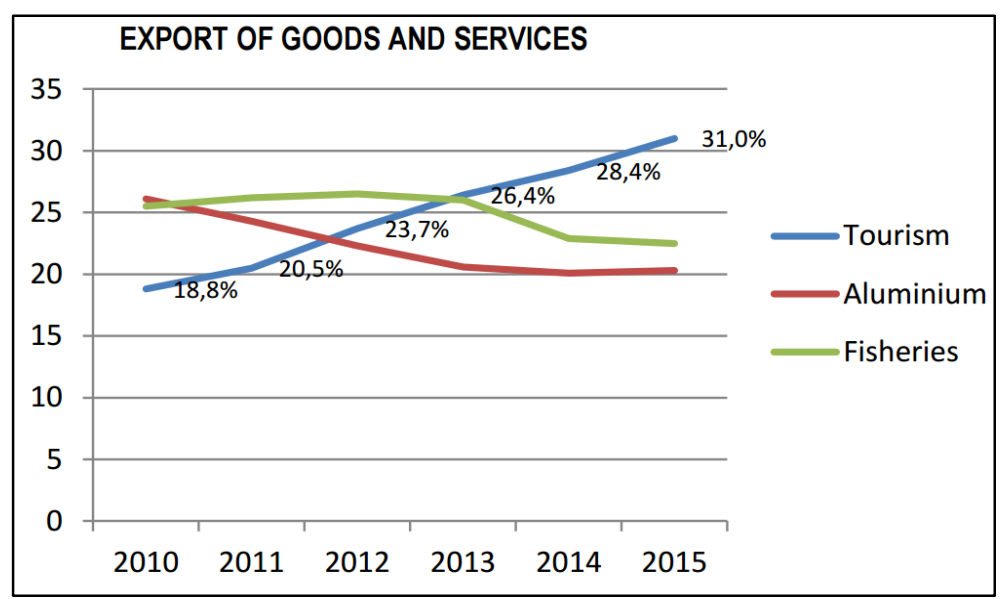

Figure 2.1: Sectoral share of total export revenues in Iceland. Sourced from Óladóttir $(2016,2)$.

A study by the Icelandic Tourist Board revealed that $75 \%$ of tourists believe that pressure on Icelandic nature by tourism is too high (Óladóttir 2016). Sixty percent of Iceland's population of 330,000 lives within the capital city region of Reykjavík, leaving much of the remainder of the Country as rural farm or uninhabitable land (Jóhannesson et al. 2010). The majority of popular tourist attractions, including the glaciers, volcanic topography, and dozens of waterfalls, exist in the rural periphery of Iceland; seasonal tourism to commonly visited attractions places increasing strain on the sites (Jóhannesson et al. 2010). Efforts are being made to protect Iceland's natural areas, but these efforts are still in their early stages of being fully understood and appreciated, and Iceland is still in the process of trying to figure out a balance between meeting economic needs while also promoting sustainable ecotourism practices. One way by which impacts to natural areas may be reduced is through the development and planning of interpretive programs and infrastructure at tourism sites using the principles of ecotourism. The 
creation of signage and development of appropriate infrastructure can be improved through understanding common visitor behavior and experience at tourism destinations.

Lindberg (1991) attempted to broadly label nature tourists using four separate classifications: hard-core nature tourists, dedicated nature tourists, mainstream nature tourists, and casual nature tourists. The "hard-core" nature tourists are described as individuals that are driven by scientific research or education. Similar to the "hard-core" nature tourist, the "dedicated" nature tourist has a desire to learn about the local environment and populations, but is also motivated, in large part, by the desire to simply see protected and natural areas. Based on the definitions provided by Lindberg (1991), the "mainstream" nature tourists are those who travel simply for recreation. Finally, the "casual" nature tourist is one who, by chance, experiences natural areas as part of a broader trip. The classification of tourists within several variations of motives and intentions is a broad generalization; however, through the creation of these classifications, Lindberg (1991) was able to illustrate what seems to be a major issue in the development of nature-based tourism destination: there exists a wide range of expectations which must be met in the development of these locations.

Being able to determine the most effective ways of influencing tourist behavior and environmental attitudes warrants understanding the types of tourists that visit Iceland. Nilsson (2012), using a framework developed by Plog (1974), distributed questionnaires to characterize tourists in the north of Iceland. In Plog's (1974) framework, tourists are divided into three distinct types: psychocentric, midcentric, and allocentric. These classifications range from the self-inhibited and nervous tourist (psychocentric) to those who want to see new things and explore the world (allocentric) 
(Nilsson 2012). Those tourists who shared equal characteristics of both were considered to be midcentric. In this model, the psychocentric tourist would be those who might expect western amenities during their stay; conversely, the allocentric tourist is one who is motivated by the possibility of new experiences. Based on Nilsson's (2012) study of tourists in Iceland, the majority of tourists were determined to align most closely with the allocentric model; however, this study was focused on wildlife tourists in the north with a limited sampling base and may not be representative of all tourists to Iceland.

To assess the attitudes of tourists on various subjects, Nilsson (2012) used a 5point Likert scale survey. The most notable finding from this study is that the majority of those polled strongly agreed with the statement, "Education is the most appropriate way to manage the behavior of people taking part in recreational activities in a wildlife area." This finding, in addition to the strong disagreement with the statement, "Humans have the right to alter nature to satisfy their wants and desires," indicates that nature tourists in Iceland seem to agree that conservation of natural areas can be promoted through informal learning. These findings support the need to understand visitor experience so that interpretive programs and built infrastructure may be developed in a way that is catered to both maintaining the health of the environment as well as satisfying the needs and expectations of visitors.

While education is suggested as the most appropriate method to manage tourist behavior in Iceland's natural areas, a report by Óladóttir $(2014,16)$ recognized that "better guidance and information provision on tours" is a common suggestion of improvement by tourists to Iceland. Based on this report, it is clear that a majority of Icelandic tourists are receptive to free-choice interpretive education methods; however, 
these programs either do not exist or do not meet visitor expectations. Further research is needed to assess the current methods pursued by the tourism industry to convey information to visitors for the purposes of education and conservation. Additionally, in order to effectively analyze development, the common ways in which visitors experience these sites must also be fully understood.

\subsection{Ecotourism as a Platform for Informal Learning}

The study of informal learning in ecotourism is still in its infancy compared to research conducted about other education-related topics. Informal learning in a broad sense refers to learning that occurs outside of the structured classroom setting (Livingstone 2007). In many cases, informal learning occurs as a result of real-world experiences; however, it can also be the pursued result of genuine curiosity and interest of the participant. In contrast, formal education refers to any education that occurs in a highly structured institution under the guidance of professional educators. According to North (2011), a person only spends approximately $3 \%$ of their lifetime learning through a formal education environment. With that said, informal and formal learning should not be considered mutually exclusive, especially considering informal learning is influenced by previous knowledge (Falk and Dierking 2000). Formal education is a critical component in the educational process. Through formal education, which predominantly occurs during a person's youth, a framework of knowledge is developed upon which we continue to learn; informal learning exists as the method by which people, as lifelong learners, continue to develop their understanding and perception of the world (Coffield 2000). Furthermore, informal learning in nature-based tourism environments, guided 
through interpretive material, has been shown to have immediate and lasting influence on sustainable behavior within natural environments (Ballantyne et al. 2011).

\subsubsection{Interpretive Signage as a Management Tool in Ecotourism}

Munro et al. (2008) suggested that, given the large number of possible variables influencing learning in natural areas and the relatively small number of studies that have been performed, no major conclusions can be drawn about the role of interpretation in environmental learning. Interpretation includes both personal and non-personal methods of communication which aim to improve and enrich visitor experience by conveying the significance of the place they are visiting (Tilden 1957). In their study, Munro et al. (2008) set out to assess the validity of studies on environmental interpretation and compare the outcomes of each. The validity of each study was assessed based on a framework including adequate sample size, methodological rigor, use of a control group, and post-experience follow-up. Of the 21 studies reviewed, none were fully validated through this framework (Munro et al. 2008). While none of the studies were validated, 19 of the 21 did consider interpretive methods successful in meeting defined management goals. Based on this study, there is currently a need for additional research on the role of interpretation in ecotourism.

While the effectiveness of interpretation is only beginning to gain intensive attention in academic research, it has been used throughout history in various parks and natural environments. Interpretation is divided into two broad categories: interpersonal and non-personal (Munro et al. 2008). Interpersonal interpretation refers to any face-toface interaction between a tourist and park staff, such as a guide. Non-personal interpretation, on the other hand, occurs between a tourist and various forms of media 
within the area, such as signs or brochures. Best practices for the implementation of interpretation in natural areas are grounded in limited certainty of actual effectiveness. While few studies have attempted to quantify the effectiveness and value of certain interpretive techniques in influencing the behavior of tourists, overarching themes and suggestions for successful interpretive programs exist (Littlefair and Buckley 2008).

The design of interpretive programs in nature-based tourism destinations should cater to the expectations held by the typical visitor in that area. In boarder surveys administered by the Icelandic Tourism Board (Óladóttir 2016), the number one motivator of tourists to Iceland is the "unspoilt" impression of the landscape. This impression lends itself to a more indirect management approach, such as the installation of interpretive signs. A study by van der Stoep and Gramann (1987) suggested that indirect approaches to managing tourism areas are favorable to both managers and tourists, as these approaches allow visitors to voluntarily alter their behavior through education and understanding.

Interpretive signs are regularly used in nature-based tourism destinations to educate visitors and discourage environmentally degrading behaviors. The design and integration of interpretive signs in any environment is a multi-faceted process which requires the consideration of a multitude of factors, including the design, placement, and tone of signs within a given landscape. Studies by Martin (1987) and Swearingen and Johnson (1988) suggest that signs invoking consequences for visitor actions may be the most effective at preventing unwanted behavior; these signs must be designed with the consideration that the tourism industry succeeds when development meets the expectations of both managers and visitors. For example, research by Ajzen and 
Fishbein (1980) revealed that humans form beliefs about an object based on whether that object is associated with positive or negative characteristics; in this instance, the design of signs in nature-based tourism areas would benefit from an educational approach that would more likely provide a positive experience for the tourist. To further assess the effect of tone on visitor behavior, surveys can be used to understand the ways in which visitors perceived the tone of various signs. Review of eye-tracking data can then be used to assess the ways in which visitors respond to these signs based on their perception of the message.

Published literature on the effective design of interpretive signs is extensive and spans several decades. One way researchers suggest that developers can create effective interpretive material is through the creation of multisensory features to engage visitors (Bitgood 2000). In his study, Bitgood (2000) revealed that engaging multiple senses may increase attention and, in turn, the perception of information within interpretive material. Multiple senses could be engaged through the use of hands-on, flip-labels which reveal certain facts to visitors when a panel is turned over; a study by Arndt et al. (1993) determined this to be a notably effective strategy for peaking participant curiosity. In terms of attracting visitors to interpretive signs, one common technique is the use of large type size (Thompson and Bitgood 1988). This concept relates to the perceived difficulty of reading and interpreting a sign. The more challenging a visitor perceives a sign to interpret, the less likely he or she is to even approach the sign (Rand 1990). For this reason, signs should focus on blocking small segments of information, about 25 to 75 words, alongside visually appealing images and figures (Serrell 1996); this idea of simplifying text and making information more digestible for the observer 
can also be done through the creation of bulleted lists rather than long strings of text. Using eye-tracking technology, the design of interpretive signs can be assessed by observing what visitors pay attention to and what sign elements attract the most attention. By better understanding how to attract visitor attention, signs can be more effectively developed in the future.

A final consideration that must be made in the development of effective educational signage is placement. In one study by Davis (2009), the most commonly stated reason respondents chose to read signs was location. Determining proper location for signs is equal parts understanding the behavior of visitors and identifying areas of interest within the environment. When placing signs, consideration must be given to where visitor attention is generally focused; if a sign is not located next to the particular feature or area it describes it is likely to go unnoticed by the majority of visitors to an area (Bitgood et al. 1990). In addition, sign placement must take into account a participant's relative gaze pattern, but these data can only be collected through the use of eye-tracking technology. For example, a visitor in an area with a rocky and somewhat challenging trail will likely focus on the ground causing signs placed higher up on the horizon to go unnoticed. Moreover, signs should be placed along a defined or perceived route. This factor can be difficult to control in certain open environments, especially during peak flow of tourists; however, the chances of a visitor engaging with a sign increases if a pathway or trail is perceived to relate to the viewing order of interpretive signs (Bitgood 2000). As a result, the collection of GPS footpath data adds meaning to mobile eye-tracking data in that being able to identify high traffic areas within an 
environment serves to reveal common points of interests and the pathways in which ecotourism destinations are explored.

\subsection{Eye-tracking and Ecotourism}

Eye-tracking is a method of study that analyzes eye movement to understand the common influences of attention and comprehension (Tanenhaus and Spivey-Knowlton 1996). Eye-tracking has applications in multiple fields from psychology to marketing. The analysis of eye-tracking data predominantly focuses on the occurrence of saccades and fixations. Saccades are rapid eye movements occurring at intervals of 10 to 100 milliseconds (Duchowski 2007). Saccades occur between fixations or stabilizations of the eye over what are perceived to be areas of interest. Fixations are believed to be an indicator of perceptual processing (Mayer 2010); thus, it can be assumed that direction of attention to significant portions of non-personal interpretations should result in a higher level of learning and perception.

In the past decade, many studies have utilized eye-tracking technology in an attempt to recognize ways to improve learning potential in both formal and informal education environments. A study by Ozcelik et al. (2009) discussed the issue of split attention, where the learner is tasked with piecing together related topics across a series of graphics and text. Ozcelik et al. (2009) used eye-tracking techniques to show that the use of color-coding is an effective method for increasing user perception and efficiency. A similar study by Beymer et al. (2008) used eye-tracking to assess the influence of font size and type on reading, finding an advantage in reading speed with larger fonts. Tsai et al. (2012) discussed implications for the study of informal learning through the use of eye-tracking technology. In this study, a group of students were tasked with answering 
multiple-choice problems using graphics as visual aids. The study found that those who unsuccessfully answered the problems often shifted their vision between relevant and irrelevant factors. While the Tsai et al. (2012) study did not make any effort to determine how prior knowledge may have influenced the perception of the graphics, the authors suggest that emphasizing relevant portions of educational graphics can influence learning potential; thus, this study is important in that it attempts to quantify learning in addition to analyzing eye movement patterns. In a critical review of the literature on eyetracking with respect to learning, Mayer (2010) suggested, in agreement with Tsai et al. (2012), that an increase in fixation on relevant information leads to an increase in understanding. In the development of sustainable ecotourism destinations, understanding ways to divulge information through effective signage and infrastructure is important; however, given the free-choice nature of informal learning, it is also important to understand visitor experience to help inform the development of interpretive programs.

\subsubsection{Eye-Tracking in Ecotourism}

More recent studies in the eye-tracking field have begun to apply eye-tracking technology in increasingly diverse environments. Evans et al. (2012) used mobile eyetracking technology (MET) in outdoor environments to assess learning of both professional and amateur geologists. While the study focused on differences in eye movements between novice and expert geologists, its main contribution to the literature of the field was the use of MET in an outdoor environment. The ability to track tourist movement and eye gaze through natural areas could help in the identification of areas of interest where interpretive infrastructure should be made available. Further, mobile eye- 
tracking data can be used to evaluate the effectiveness of existing signs in achieving intended goals.

Nature-based tourism destinations are the ideal study areas for use of MET since the use of interpretive signs is prevalent in these areas. At these destinations, whether or not a tourist chooses to seek out available information is entirely by free-choice. By understanding the ways in which tourists typically explore natural areas, and the factors that influence what tourists pay attention to while exploring, education can be encouraged through adaptation of current interpretive practices. As a result, Keifer et al. (2012) proposed location aware mobile eye-tracking (LA-MET) as an emerging and valuable field. In their study, hot spots for map usage were determined through the joint use of GPS and MET technologies; in short, their pilot study emphasized informal learning from a spatial perspective. Many issues, from the influence of proper tourist behavior to the development of effective learning environments, can be recognized and remedied through the use of LA-MET, yet no readily available literature exists for the use of LA-MET in the ecotourism industry. LA-MET, coupled with pre- and postassessments and semi-structured interviews, can be used to help develop accurate evaluations of scan patterns and maximize opportunities for learning at ecotourism sites.

\subsection{Summary}

Ecotourism has emerged as one subsect of sustainable alternative tourism practices. Commonly stated principles of ecotourism include both the conservation of natural environments and the promotion of education (Fennell 2003). Iceland is one nation which has seen dramatic increase in inbound tourist numbers in recent years. Between 2010 and 2015, the number of inbound tourists to Iceland increased from 
448,000 to nearly 1,300,000 (Óladóttir 2016). In a series of polls by the Icelandic Tourism Board the unspoilt impression of the landscape has been consistently ranked as a top motivation for visiting Iceland. The tourism industry has become Iceland's primary industry, yet the recent success of the tourism industry has brought about conflict between economic development and environmental conservation given the rapid rate at which the industry has developed. Recently, however, stakeholders in the tourism industry have highlighted the need to protect Iceland's natural areas while also sustaining tourism activity (Jóhannesson et al. 2010).

The largely rural nature of Iceland presents one challenge in the effective management of tourism destinations. In these environments, information is often disseminated to tourists through the implementation of interpretive signs and visitor behavior is influenced by the development of trails and the designation of restricted areas. Given the recent rise of tourism activity in Iceland, many sites are still in the process of being developed. A common suggestion that has been made amongst visitors to Iceland is "better guidance and information provision on tours" (Óladóttir 2014, 16). Despite the abundant use of interpretation throughout ecotourism destinations globally, a large number of variables exist which contribute to the effectiveness of interpretive signs at managing tourist behavior. Furthermore, given the large number of factors which contribute to effective interpretive material, a relatively small number of studies have been conducted on the role of interpretation in environmental conservation and learning (Munro et al. 2008). This study puts forth that MET should be used as a method to establish the best ways to manage visitor behavior at ecotourism destinations. Past applications of eye-tracking technology have focused on education within static formal 
environments. Recently, however, with the advancement of MET, studies have begun to use the technology in increasingly diverse environments. While no readily available literature exists on the use of MET in the tourism industry, previous studies have shown that the technology can be a telling indicator of user perception in outdoor environments (Evans et al. 2012). 


\section{Chapter 3: Study Area}

This study was conducted at two locations in the island nation of Iceland (Figure 3.1). Iceland is roughly $103,000 \mathrm{~km}^{2}$ and is located in the North Atlantic Ocean at approximately $63^{\circ}-67^{\circ}$ north and $18^{\circ}-23^{\circ}$ west between Greenland and western Europe (Ingólfsson n.d.a). The climate in Iceland, as defined by the Köppen classification system, is cold oceanic. Given its northerly latitude, just south of the Arctic Circle, Iceland should experience a colder climate, but the influence of the thermohaline circulation of the Gulf Stream creates a more temperate climate (Ingólfsson n.d.a); specifically, temperatures in southern Iceland fluctuate between highs of $25^{\circ} \mathrm{C}$ in the summer months to average lows of $0^{\circ} \mathrm{C}$ in the winter months (Ingólfsson n.d.a), which promote a year-round tourist presence in Iceland. 


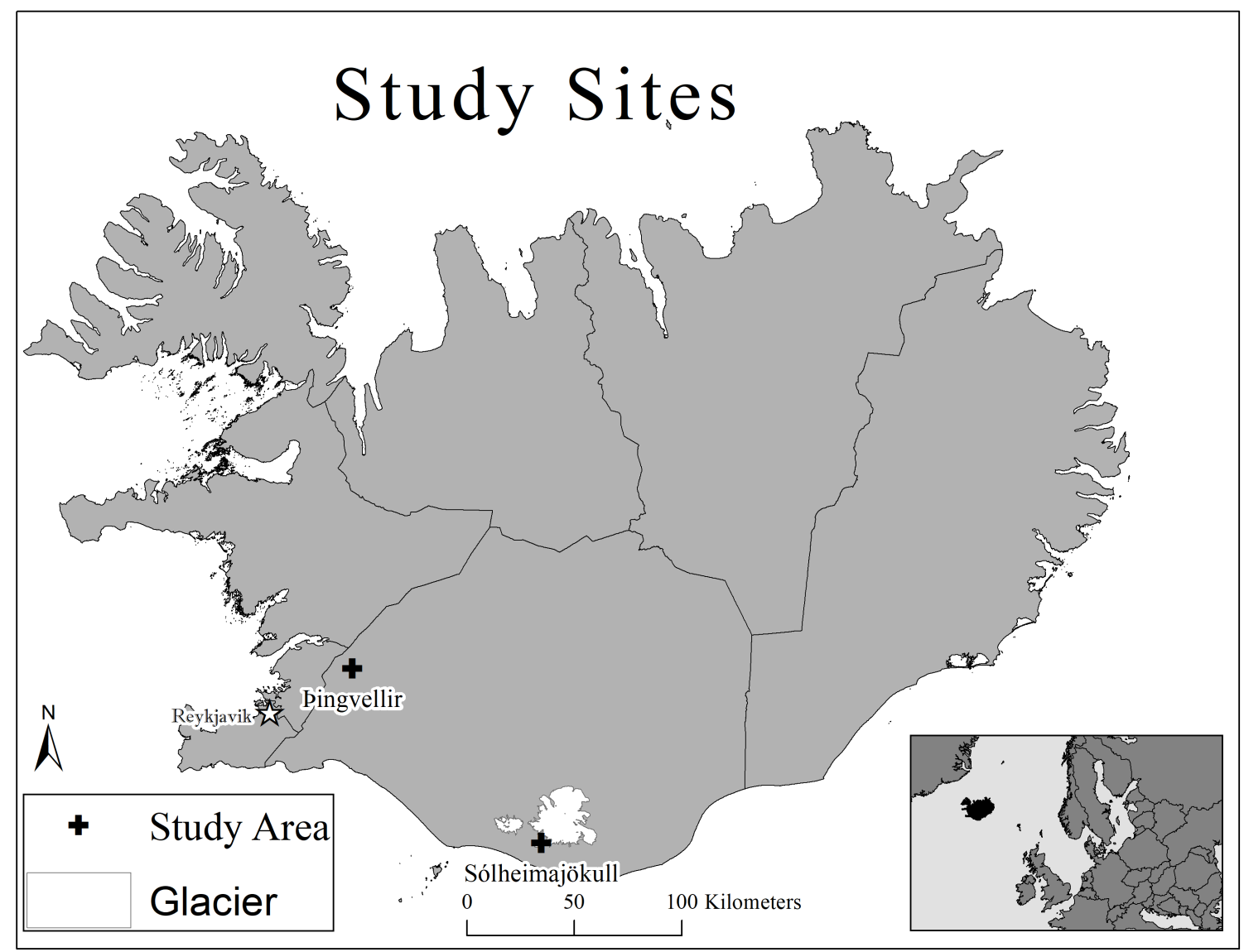

Figure 3.1: Map of study areas (created by author).

Compared to its size, Iceland possesses an incredibly diverse range of environments. From its coasts to highland plateaus, Iceland is characterized by considerable glaciation, waterfalls, volcanoes, and various geological phenomena, such as lava tubes and visible tectonic rifts. Amidst the southern and central plateaus of Iceland, glaciers are dominant features in the landscape. In total, glaciers cover approximately $11 \%$ of Iceland's landmass, and are particularly dominant in the southern and central highlands (Björnsson and Pálsson 2008). Vatnajökull, is not only the largest ice cap in Iceland, but also in all of Europe (Ingólfsson n.d.b). The combined freshwater volume of Iceland's glaciers, $3,600 \mathrm{~km}^{3}$, would be equal to an ice layer $35 \mathrm{~m}$ in depth if spread across the entire country (Björnsson and Pálsson 2008). Glaciers in Iceland have 
a dynamic relationship with the landscape, due to their temperate nature. The mass balance of glaciers in Iceland is dependent on several variables, including precipitation and glacial melt at lower altitudes (Tómas 1997). The temperate glaciers in Iceland are, therefore, in stark comparison to polar glaciers at higher latitudes, which remain relatively water-free throughout the year (Ritter 2006). The dynamic relationship between accumulation and ablation in Icelandic glaciers has allowed for significant hydrological development including intricate networks of lakes, rivers, and waterfalls.

In addition to being numerous and widespread throughout Iceland, many waterfalls in Iceland are incredibly powerful. For example, Dettifoss, which is fed by meltwater from the Vatnajökull ice cap, is considered one of the most powerful waterfalls in Europe. Brandenburg (1998) suggested that if Dettifoss were to be used as a hydropower plant, its output would be close to $100 \mathrm{MW}$, enough energy to power approximately 100,000 homes. The hydrological features resulting from glacial melt in Iceland are some of the country's greatest resources, providing $71.7 \%$ of Iceland's energy (Loftsdóttir 2016) and ranking as the most popular attractions among tourists and islanders (Óladóttir 2015).

Volcanic activity is prevalent in many portions of Iceland. The high degree of volcanism in Iceland is due to its position over the mid-Atlantic ridge, a divergent boundary between the North American and Eurasian plates. Due to this tectonic boundary, volcanic eruptions occur in Iceland every three or four years with varying intensity (Gudmundsson et al. 2010). Eruptions can range from lava flows to more explosive outbursts with massive ash plumes. The eruption of the Eyjafjallajökull in 2010 received heavy media coverage when its ash cloud brought air travel to many parts 
of the world to a halt for several weeks. Following the eruption, debate arose about whether or not the event would have negative implications for Iceland's tourism industry; Benediktsson et al. (2011) documented that the 2010 eruption actually inspired tourists to visit Iceland by increasing visibility of both the country and its landforms.

\subsection{Tourism in Iceland}

Tourism in Iceland has increased exponentially in recent years. In the period between 2010 and 2015, the number of annual tourists in Iceland increased nearly 164\% from 488,600 to $1,289,140$ (Óladóttir 2016). This trend has resulted in tourism being the leading industry in Iceland. All Icelandic tourism operations represent $31 \%$ of the foreign income exchange and have created 21,600 jobs (Óladóttir 2015; Óladóttir 2016). In 2015, total inbound tourism consumption contributed more than 263 million Icelandic kronor to Iceland's economy (Porsteinsson 2017). Following the recent collapse of Iceland's banking sector, the success of the tourism industry has been suggested as an option for development in Iceland (Jóhannesson and Huijbens 2010).

As aforementioned, the recent explosion in Icelandic tourism is at least partially attributed to the 2010 eruption of Eyjafjallajökull. In the year prior to the eruption, Iceland experienced a $1.1 \%$ decrease in tourist numbers. In the year following the eruption, an increase of $16.6 \%$ was documented, followed by an increase of $18.9 \%$ in the 2011-12 tourism season (Óladóttir 2012). After the eruption of Eyjafjallajökull, Iceland began to promote its tourism industry to try and curb the fear of sporadic volcanism (Benediktsson 2011). The promotion of the tourism industry, coupled with the excitement caused by the eruption, highlighted Iceland as a nature tourism destination. 
The Icelandic Tourist Board publishes an annual report on tourism which details the demographics, interests, and suggestions of both tourists and Icelanders for the tourism industry. Among nearly all of these reports, the natural environment and desire to learn about Icelandic culture and history have been ranked as the top motivators for travel to Iceland (Óladóttir 2012; 2013; 2014; 2015). Of the thousands of visitors to Iceland, annually, the vast majority travel from the United States, the United Kingdom, Germany, France and other Nordic countries; however, tourists travel to Iceland from all regions of the world (Óladóttir 2016). In terms of managing tourist activities through interpretive signs, the diversity of these demographics presents an interesting challenge in that signs and other management methods must effectively communicate across multiple linguistic barriers.

A 2016 report by the Icelandic Tourist Board surveyed tourists for suggestions to the development of the tourism industry. Of those surveyed, $26.2 \%$ suggested environmental issues and tourist behavior must be a focus moving forward (Óladóttir 2016). The same report also revealed that $75.7 \%$ of individuals surveyed believed that tourism pressure on Icelandic nature is too high. Additionally, tourist polls have suggested that to properly manage tourism in Iceland monitoring and managing tourist numbers would be beneficial (Óladóttir 2016).

When asked what inspired tourists to visit Iceland, the most common response regularly includes the unspoiled impression of Icelandic nature (Óladóttir 2017); yet, the pressures placed on Icelandic natural areas by the large influx of tourists has negative impacts, including environmental degradation. A study by Olafsdottir and Runnström (2009) used geographic information systems (GIS) to map regions sensitive to 
environmental degradation in Iceland and identify areas where tourism should be limited. Further, the Environmental Protection Agency of Iceland has suggested that the most vulnerable natural areas in Iceland are among the most popular tourism destinations in the country (Uhmverfisstofunn, 2017a). The agency's "Welfare for the Future" report has demanded investigation of the carrying capacity of these sites and has encouraged the marking of trails, increased supervision at sites, and development of education resources to promote conservation (Uhmverfisstofunn, 2017a). Overall, while it is important to recognize these areas, the use of trails and interpretive signage can help manage conservation while also allowing opportunities for informal education in many of Iceland's natural and vulnerable areas.

\subsection{Areas of Interest Within Iceland}

This study focused on two popular nature-based tourism destinations in Iceland. The study areas, Pingvellir and Sólheimajökull, were chosen in order to incorporate tourism sites of varying cultural and environmental significance, as well as visitation by tourist (Figure 3.1).

\subsubsection{Pingvellir}

Pingvellir National Park is considered the most historically-significant site in Iceland (Hlöðum, 2015). Given its close proximity to Reykjavík, the capital of Iceland, Pingvellir is also one of the most visited tourism destinations. The world heritage park is home to the Almannagjá rift zone between the Eurasian and North American plates. With visible fissures and astounding scenery, including Lake Pingvallavatn, Iceland's largest natural lake, the Pingvellir area draws approximately 674,000 visitors each year 
(Centre, n.d.; Óladóttir 2016). While Pingvellir holds great geologic worth, its cultural significance is no less impressive. Established in 930 AD, Pingvellir became the meeting place for the Alpingi, which is often considered the world's first parliament.

Specifically, while it varies from today's vision of parliament, the Alpingi represents the first time in history a governing body of equal members ruled over an entire nation. The Alpingi was composed of 48 Goðar, who voted upon new laws and amended those already in existence (Bell 2010). A flag marks what is likely the site of the Lögberg, the cliff where laws were once recited (Figure 3.2) (Hlöðum, 2015).

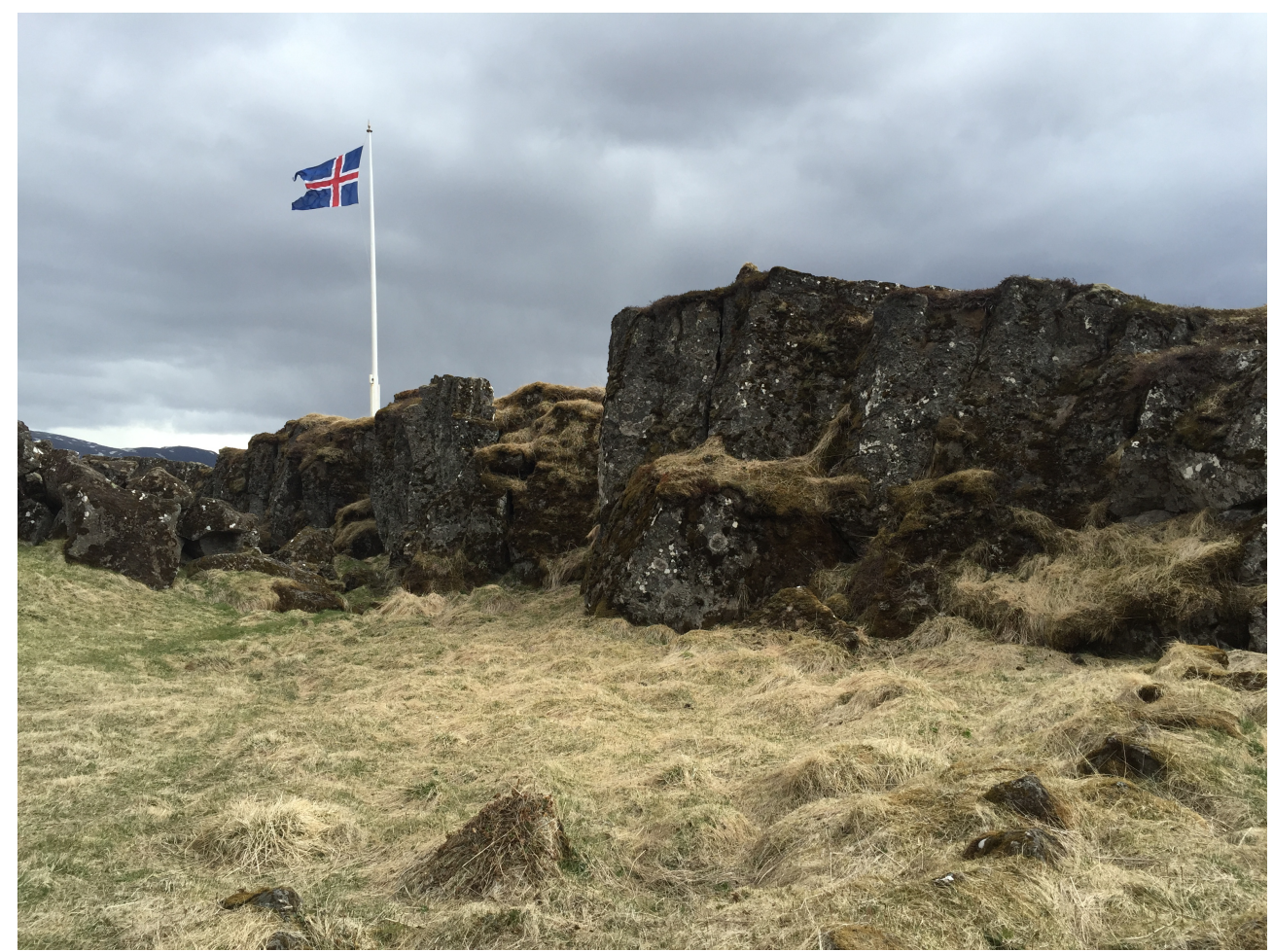

Figure 3.2: Lögberg at Pingvellir National Park (photo by author).

Pingvellir was chosen as a study site for this research, because of its relevance as a culturally significant location and its proximity to Reykjavík. A visitor center at the entrance of Pingvellir presents guests with a multimedia exhibit that includes relevant 
information about the area such as native species of flora and fauna. Pingvellir also has multiple paved parking areas and restrooms on site. A gift store offers light beverages and snacks. Picnic tables are distributed throughout the site.

As a national park, bingvellir managers must adhere to mandates put in place by the division of nature conservation which require the development of trails and interpretive material to educate visitors on the cultural and natural heritage of the region (Uhmverfisstofunn, 2017b). At Pingvellir, 11 informational signs are provided for visitors; these signs focus on information related to a wide variety of information from the local biology to the history of the site. In addition to the informational signs, an additional 59 management signs designed to discourage visitors from walking off trail are displayed throughout Pingvellir. Differences between educational and management signs are shown in Figure 3.3. Guiding visitors throughout Pingvellir National Park is a network of well-defined trails and boardwalks which are easily distinguished from the surrounding landscape.
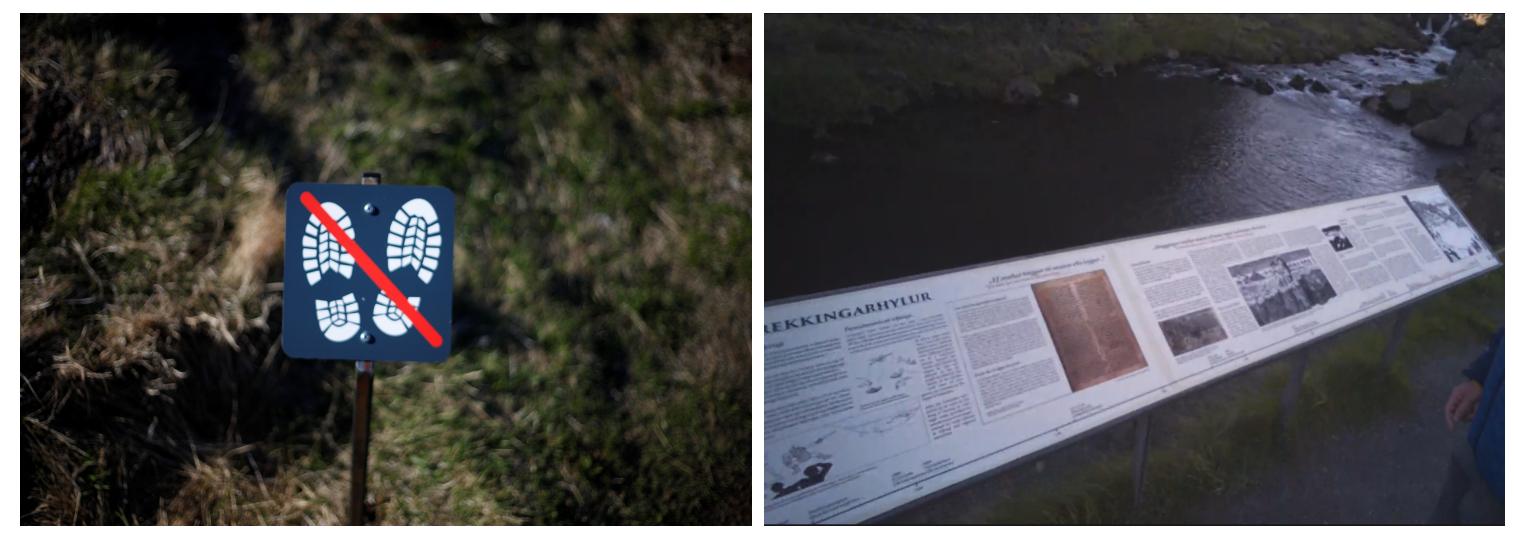

Figure 3.3: Management sign vs. educational sign at Pingvellir National Park (photos by author). 


\subsubsection{Sólheimajökull}

Sólheimajökull is one of many outlet glaciers in Iceland. The glacier itself is 15 km long and extends from the Mýrdalsjökull ice cap in southern Iceland (Friis 2011). Recent climatic change has caused the glacier to retreat nearly $800 \mathrm{~m}$ in the last two decades (Friis 2011). Sólheimajökull represents only a small portion of the glaciers in Iceland; however, it is a well-studied and documented glacier that shows what has become a seemingly global trend in glacial retreat (Staines et al. 2015). Sólheimajökull has additional environmental significance in that it drains the Mýrdalsjökull ice cap, which sits on top of Iceland's largest sub glacial volcano, Katla (Russell et al. 2010). The Sólheimar glacier is one of Iceland's most popular nature-based tourism destinations, attracting nearly 210,000 visitors annually (Óladóttir 2016).

The Sólheimar glacier (Figure 3.4) was chosen for this study for several reasons, including its significance with respect to climate change. The glacier was featured in the documentary, Chasing Ice, which followed National Geographic photographer, James Balog, in his attempt to document the glaciers rapid retreat (Orlowski 2012). The retreat documented in the film may contribute to the popularity of Sólheimar and other glaciers among ecotourists, as visitors attempt to see the landforms before they disappear. 


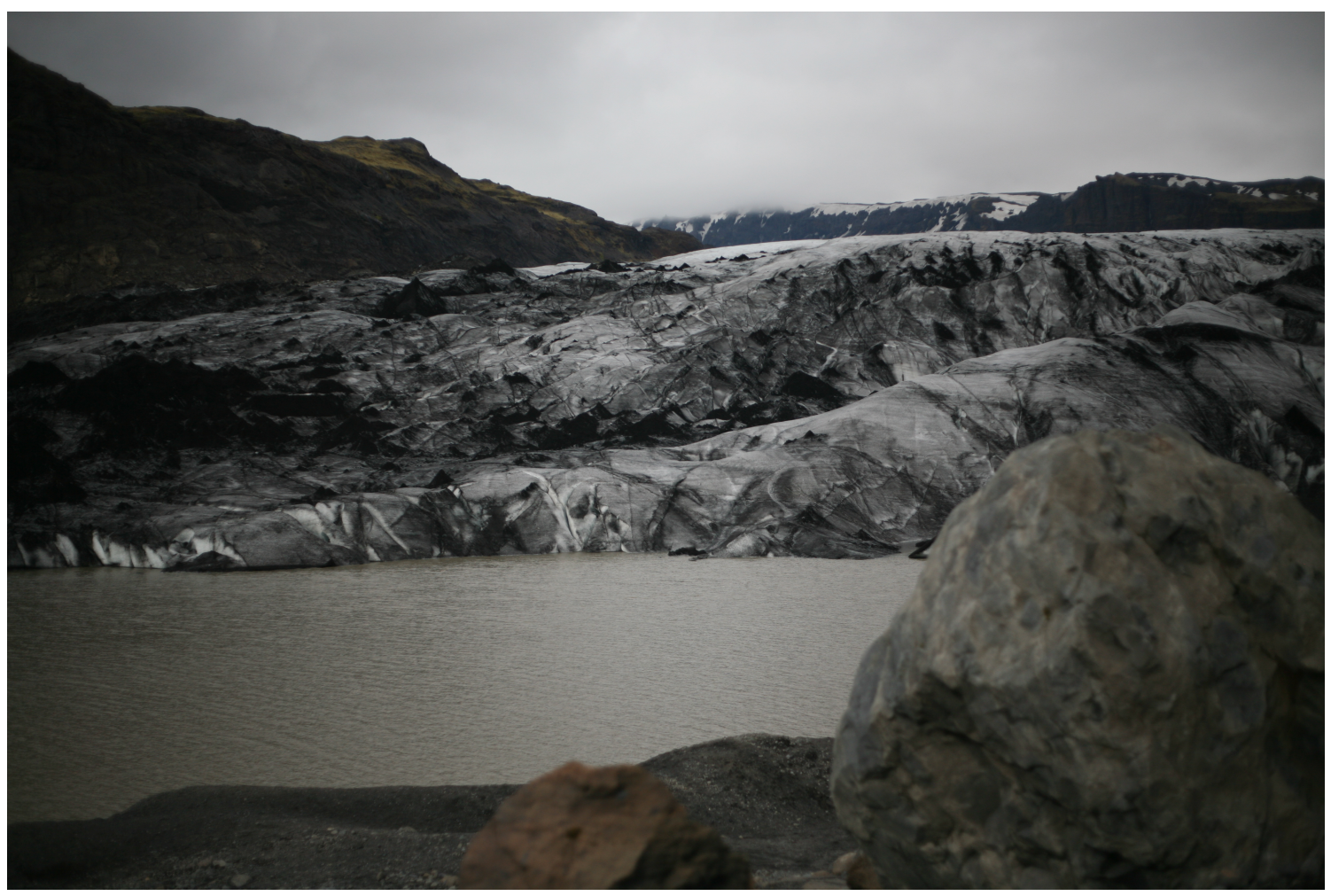

Figure 3.4: Sólheimajökull tourism destination (photo by author).

Sólheimajökull is located along the southern coast of Iceland approximately 140 kilometers east of Reykjavík. Due to the glaciers distance from Reykjavík, it receives less visitors annually than Pingvellir, but since the site is accessible from both Reykjavík and Vík, a popular tourism destination town on the southern coast, Sólheimajökull is one of the more popularly visited glaciers in Iceland. Considerably less development has occurred at Sólheimajökull than at Pingvellir. The Sólheimajökull tourism site has an established parking area and café. Trails, which traverse the somewhat unstable surface of the glaciers lateral moraine, lead to the glacier face and glacial lagoon. Glacier tours are offered here with trained guides, but visitors are also welcome to walk around the area without a guide.

Signs are installed to discourage guests from walking onto the glacier unsupervised; however, their effectiveness is not documented. Unlike Pingvellir, which 
has 59 installed signs, there are only three signs along the trail at Sólheimajökull which discourage visitors from deviating from designated paths and areas. In terms of informational signs, three are present at Sólheimajökull; information provided on these signs features processes of glacial formation and retreat. Additionally, unlike Pingvellir, which has signs distributed throughout the tourism site, all of the informational signs at Sólheimajökull are present at the trail head. The lack of development that has occurred at Sólheimajökull allows for interesting comparisons to be made with the development of Pingvellir. Additionally, the potentially dangerous environment at Sólheimajökull exists as an ideal location to assess the effectiveness of interpretive signage as a means to alter visitor behavior at ecotourism destinations. 


\section{Chapter 4: Methodology}

This study used a mixed methods approach to assess visitor experience and management models at two popular nature-based tourism destinations in Iceland:

Sólheimajökull and Pingvellir National Park. The methods used in this study included post-visitation assessments, mobile eye-tracking (MET), GPS footpath collection, and observational data collection and analysis. These methods were used together to analyze visitor footpaths, gaze patterns in the landscape, and behavior in an attempt to recognize trends in visitor experience at each of the two study sites (Figure 4.1).

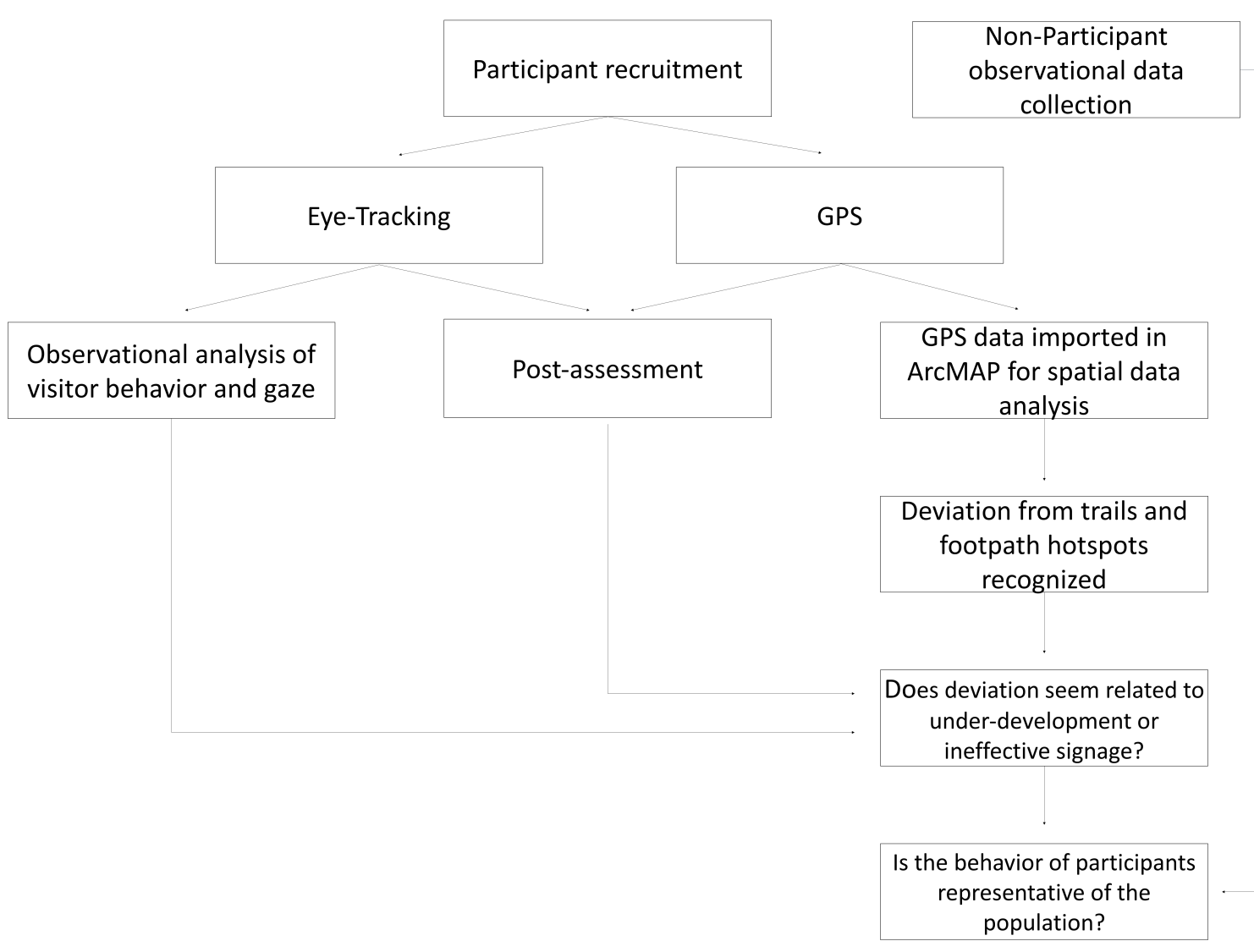

Figure 4.1: Flow chart of data collection and analysis (created by author). 
After recruitment, eye-tracking participants were outfitted with the Tobii Pro Glasses 2 as well as a Garmin Montana 680 GPS device set to log location every five seconds. GPS data were used to identify areas of interest within both study sites. Eyetracking data were useful in identifying influential factors on visitor behavior within the identified areas of interest and also served to show trends in visitor interaction and perception of interpretive signs. Post-assessment responses were compared with both GPS data and eye-tracking data to determine whether observed participant behavior aligned with specified visitor expectations and intentions. Finally, to assess whether participant behavior was representative of the population, observations regarding nonparticipant behavior were collected; these observations were compared to conclusions drawn regarding behavior and experience of eye-tracking participants to determine if wearing the eye-tracking glasses caused participants to behave in a way that was uncharacteristic of normal visitors.

\subsection{Participant Recruitment}

Prior to data collection, approval for the proposed research design was obtained from the WKU Human Subjects Institutional Review Board. Fifteen volunteers participated in an eye-tracking trial at each study site. An additional 35 respondents were completed a post-visitation assessment. All eye-tracking trials for each study began and ended at the same location for each guest; this location also served as the point where recruitment occurred.

Participant recruitment for the study occurred on site through a semi-random voluntary sample design. For this particular study, it was not possible to pre-screen participants as it could not be determined who the visitors to the study areas would be on 
any given day. While the chosen methodological design had the possibility to introduce bias, every potential participant was approached while entering the study area to limit the inherent bias of participant screening. Furthermore, the time needed to complete an eye-tracking trial increased the likelihood that participants would be less similar; this notion relates to Tobler's Law (Miller 2004), which states that nearer objects, or in this situation, people, are likely to be more similar. Provided that nearness is related to both space and time, it can be assumed that increasing the time between samples reduced the potential of recruiting members who might, for example, be part of the same tourist group. Overall, given the sampling method and time between each recruitment, this study was able to produce results from participants of varying gender, age, country of origin, and race, as well as with different motives for visiting the site and prior knowledge of the study area.

\subsection{Mobile Eye-tracking Trials}

After reviewing the informed consent document, participants took part in a location aware-mobile eye-tracking (LA-MET) trial. For this portion of the study, participants were equipped with a Tobii Pro Glasses 2 mobile eye-tracking unit and a compact GPS data logger in an attempt to assess visitor experience throughout one of the two study sites. The Tobii mobile eye-tracking unit (Figure 4.2) consists of a compact glasses frame and recording unit. The glasses are equipped with four infra-red eye cameras capable of tracking pupil and gaze patters with high resolution of 50 to 100 Hz. On the front of the glasses frame is a full HD scene camera with $52^{\circ}$ of vertical and $82^{\circ}$ of horizontal view (Tobii 2016b). Using the Tobii Pro Glasses 2, this study collected visual accounts of visitor experience in Icelandic tourist destinations. 

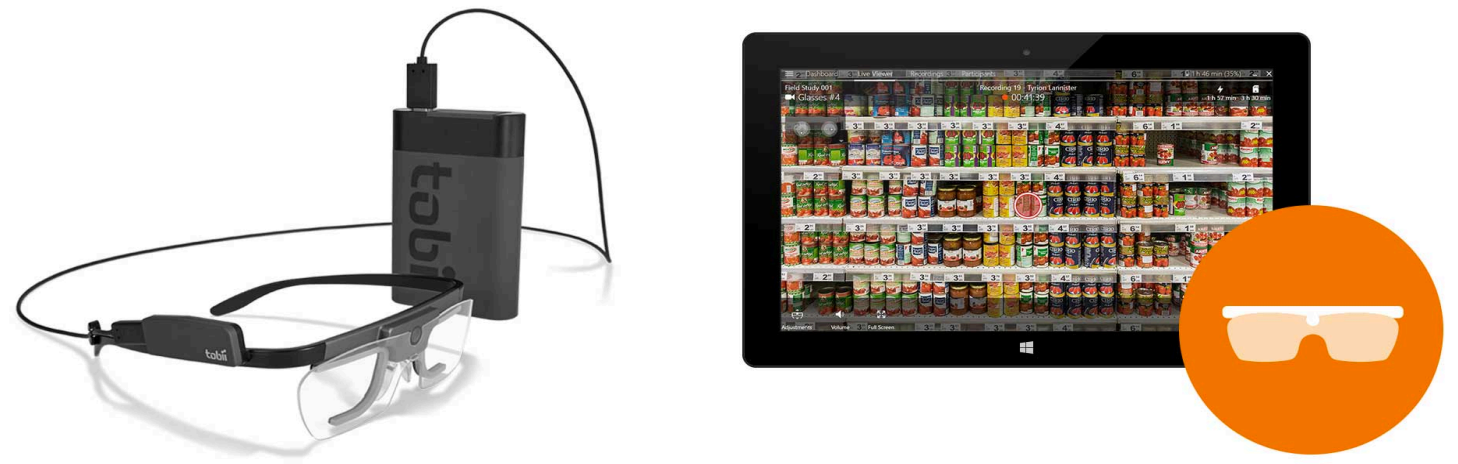

Figure 4.2: Tobii Pro Glasses 2 mobile eye-tracking unit. Sourced from Tobii (2017).

Additional materials were needed to use the Tobii glasses in this study. To operate the glasses a tablet with Windows Version 8 or later is required. Tobii Controller, a software used to store and organize projects, calibrate the device, and begin and end a recording, is also necessary. In order to perform analyses, such as heat map generation, Tobii Analyzer software was installed on the Windows device. The eyetracking data were stored on SD cards and backed up to three alternative sources, two external hard drives and an online cloud storage service, following each trial.

In addition to tracking visitor gaze throughout a study site, this study used a handheld GPS data logger to collect visitor footpaths. Trails are often used in naturebased tourism areas in an effort to decrease ecological impacts and to guide visitors through the area (Boyd and Butler 1996). Through the analysis of footpaths, this study aimed to identify whether footpaths, with the aid of interpretive signage, are effective approaches for preventing environmentally degrading behavior. Additionally, the placement of interpretative materials was compared with hotspots for visitor foot traffic at each study site. 
To collect footpath data, a Garmin 680 handheld GPS unit was situated inside of a backpack that each eye-tracking participant wore. To increase the accuracy of the data points, a Garmin 25MCX remote antenna was fixed to the outside of the backpack.

Garmin's waypoint and track applications were used to collect signage point features, as well as trail and footpath polylines. Tracks were collected using a set interval of three seconds with an accuracy as precise as three meters. These data were collected in .GPX format so that they could be imported into ArcGIS for analysis and the spatial selection feature was used to identify all footpath points falling outside of a trail buffer. In addition to participant footpath data, GPS points were collected for trails, signs, and points of interest within each study site. These data were collected in order to compare trends in visitor footpaths with site infrastructure.

\subsubsection{Workflow}

LA-MET trials took place immediately after a participant reviewed the informed consent document. Before beginning the eye-tracking trials, steps were taken to ensure the gear was prepped for the study. For example, batteries were charged daily for both the Tobii glasses, field PC, and GPS logger. Additionally, the sensors and lenses were regularly cleaned with a microfiber cloth throughout each sampling day, and the Tobii device was fit for each participant individually using interchangeable nose pads. Individual calibrations of the eye-tracking device to each participant were done prior to each trial after the glasses were adjusted to fit the participant.

When the participant was ready to begin, the eye-tracking recording was started using the Tobii controller interface and the glasses were then unplugged from the laptop. The participant was then told to walk through and experience the park as they would 
normally and was instructed to return when they had finished. After the participant returned, the glasses were reconnected to the computer and the recording was stopped. The participant was then administered the post-visitation assessment. While the participant was completing the assessment the data from the trial was backed up to two external storage devices, with the SD cards reformatted after each trial.

File structure for this portion of the study is shown in Figure 4.3. Each trial was saved individually within the study area sub folder of the main project folder on the operating device. Before starting a recording, a new participant file was made. Each participant was identified using a naming convention that consists of both the study area and trial number; for example, eye-tracking data for the first participant at the Sólheimar glacier was cataloged as ET_Sol_01. This naming convention helped to keep the data organized and protect the identity of each participant. All other records, including footpath data assessments, were cataloged with the same naming convention. All data were stored digitally on a password protected external hard drive and backup flash drive.

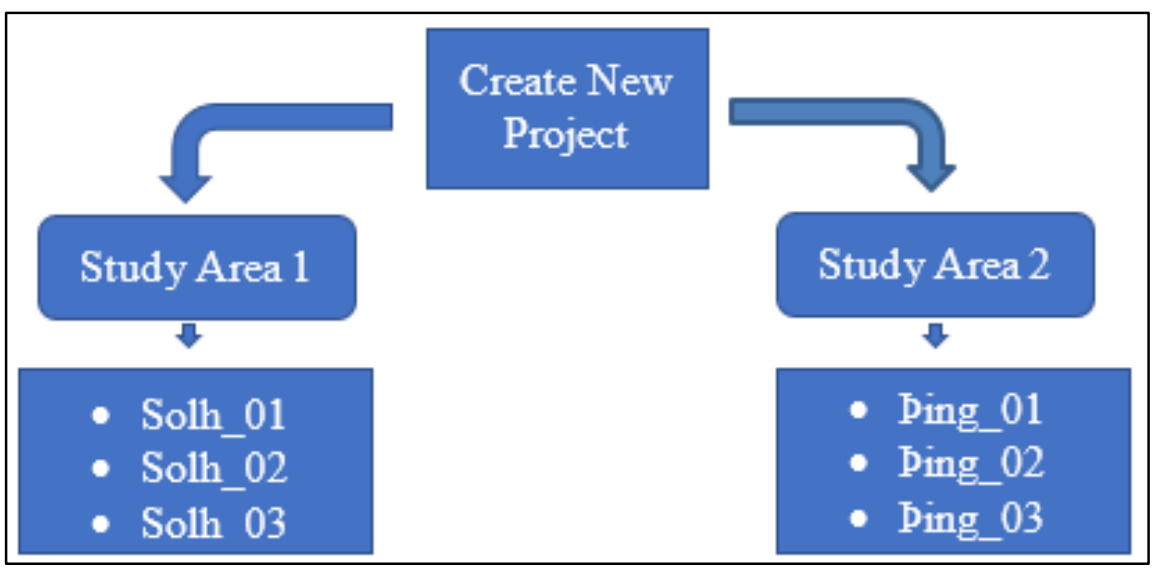

Figure 4.3: File structure for Tobii Controller interface (created by author). 


\subsection{Post-visitation Assessments}

Each LA-MET trial participant completed a post-visitation assessment immediately following their return to the site of departure. The assessment was also administered to an additional 35 respondents at each study site after they explored the location. The assessment included six Likert-scale statements, three open-ended questions, and demographic prompts (Appendix A). The content of the assessment was aimed at assessing participant experience at each site and gathering feedback as to what may be done to improve the overall experience within each destination.

\subsection{Observational Data}

For each eye-tracking participant, observations were made regarding their behavior within the study site. This was done through review of the eye-tracking footage collected during their visit to the study site. Types of behaviors that were recorded included deviations from the trail, reading and response to signs, and interesting dialogue which occurred between the participant and any individual who he or she might have been communicating with during the site visit.

In addition to the observations that were made regarding participant behavior through the eye-tracking device, observations were also collected about non-participant behavior within the two study areas. At each study site, the researcher would walk through the area once every hour to record observations about visitor behavior. Nonparticipant observations were collected so that the observations made regarding LAMET participant behavior would have a basis for comparison. Specifically, once broad conclusions were drawn regarding participant behavior at the study sites, they were then 
compared to observations made of non-participants to determine whether or not wearing the Tobii glasses influenced participant behavior within the study areas.

\subsection{Data Analysis}

\subsubsection{Visitor Footpath Analysis}

Using the GPX. to feature tool, GPS footpath data were imported into ArcMap, an application software of ArcGIS by Environmental System Research Institute (Esri). Within ArcMap, a buffer of five meters was created around the trail point feature. A buffer of five meters was chosen to account for the three-meter accuracy reported by the GPS device and any lateral movement on the trail. This buffer was used to clip the footpath shapefile to determine the areas where visitors deviated from the trails. These data were useful in determining underserved trail areas that might be adding to environmental degradation.

To identify hotspots of tourist visitation, kernel density analysis was performed

within ArcMap. Kernel density is used to calculate the density of point features within a area around an input feature. Footpath data for individual participants was merged in order to create a single shapefile containing all footpath data. This shapefile was then used as the input feature for analysis. The output shapefile was a raster which showed point density per unit area within the spatial distribution of all points. This allowed for the identification of areas that receive a higher level of foot traffic within the study sites.

\subsubsection{Post-visitation Assessments}

The Likert-scale statements and open-ended question responses were analyzed using separate methodologies. For the Likert-scale statements, frequency was plotted 
using Microsoft Excel. Frequency was calculated for eye-tracking participants separately from those study participants who only completed the post-visitation assessment. This was done to assess if those who participated in the eye-tracking trial responded differently than those who only completed the assessment using the Mann-Whitney $\mathrm{U}$ test. The Mann-Whitney U test is a non-parametric test that compares two unpaired samples to determine whether or not the samples come from identical populations.

To analyze the open-ended responses, standard methods of coding were used (Esterberg 2002). Responses were read through once to become familiar with the responses and a second time to develop themes. Themes were then assigned colors and numeric symbols. After color coding the responses, their occurrence was tallied and plotted in Excel to show frequency of common responses.

\subsubsection{Eye-tracking Trials}

The eye-tracking data collected in this study were largely analyzed using qualitative methods; however, quantitative analysis of eye-tracking data also occurred. Heat maps were generated to show interesting trends in human behavior, though poor gaze sampling due to UV interference limited definitive quantitative analysis through heat maps. To generate heat maps, Tobii's analyzer software was used and fixation points were manually mapped over top of snapshot images of the environment. Specifically, as the Tobii analyzer software moved from frame to frame showing the visitors' gaze in each moment, the corresponding point was marked on the snapshot image. After mapping each gaze spot for the entire time of interest, the points were overlaid with one another to create heat maps for visitor attention. The heat map function utilized in Tobii's Analyzer software is similar to a kernel density calculation 
where the density of fixation points is mapped using graduated colors to represent areas of higher and lower density.

Additional examination of eye-tracking data was conducted using standard methods of coding for both audio and visual data. A study by Weston et al. (2001) revealed that coding is not a pre-defined method by which interviews are analyzed. Instead, coding is an active process of interpretation used to examine textual data (Basit 2003). The specific themes analyzed while coding cannot be determined without first conceptualizing the responses of the participants. For this reason, the identification of themes did not occur until after the dialogue recorded in the eye-tracking trials was transcribed and reviewed multiple times so that the researcher was familiar with the complete dataset. In order to develop codes for analysis, each interview was read a total of two times following transcription: once to become familiar with the content and a second time to identify common themes. These themes were then divided into various codes and subcodes and color coded for each participant. After all transcriptions were coded, code frequency was calculated for each individual participant, as well as the total for all participants at each site. Comparing these results to those of the open-ended response questions on the assessment instrument highlighted similarities and inconsistencies in the findings of these data sets.

In addition to transcribing participant dialogue, relevant participant behavior such as deviation from trails and responses to posted signage was also recorded. The purpose of this study was not only to explore informal learning in natural areas, but to understand the effectiveness of interpretive signage and infrastructure in preventing unwanted visitor behavior; part of assessing the effectiveness of signs and site 
development is considering its placement. For this reason, the eye-tracking trials were played back to determine whether or not visitors sought out signs in the two study areas. Through observation of the trial playback, factors that may have influenced a visitor to approach or avoid a sign were observed. By observing a visitor's actions after having viewed such signs, it could be determined whether or not they are effective in influencing visitor behavior. Furthermore, by observing trial playback, factors that may have caused a visitor to deviate past a sign, as well as common factors for effective sign development, were identified.

\subsection{Limitations}

Recruitment for participation in this study was limited to those individuals who spoke English. While language is certainly a study limitation, potential participants who spoke English as a second or even third language were still encouraged to participate so long as they were able to interpret the informed consent document and complete the post-visitation assessment. An additional limitation existed in the fact that the Tobii Pro

Glasses 2 were designed for use in indoor environments. Incoming infrared light has the potential to disrupt readings from the glasses infrared cameras. This caused variable levels of gaze sample collection depending on the fluctuations in weather and the time of day at which trials were run. Finally, there was the potential that use of the glasses may have caused visitors to act out of character. In order to reduce this potential limitation certain aspects of the study, such as the full intent of the study and the ability of the eyetracking equipment to record audio, were omitted from the informed consent document that was approved by the Western Kentucky University Human Subjects Review Board. 


\section{Chapter 5: Results and Discussion}

The purpose of this study was to assess methods of tourism development and visitor experience at two popular, yet distinctly different, tourism destinations in Iceland. The methods used in this study included mobile eye-tracking, GPS footpath data, postvisitation assessments, and observational data collection. The two study sites, Pingvellir National Park and Sólheimajökull, were selected because they represent two popular Icelandic tourist attractions with varying levels of infrastructure development and tourist engagement. At each study site, individuals were selected through a voluntary, semirandom sample design to participate in the study. After recruitment in the study, participants were outfitted with a pair of Tobii Pro Glasses 2 mobile eye-tracking glasses and a Garmin Montana 680 handheld GPS unit and instructed to explore the study sites as they would normally and return to the starting point once they had finished.

Following their return, eye-tracking participants were administered a post-assessment (see Appendix A), which consisted of six Likert-scale statements, three open-ended questions, and demographic prompts to answer. At each study site, 15 participants were recruited to participate in mobile eye-tracking trials. Additionally, another 35 respondents were recruited at each study site to complete post-assessments. Demographics for eye-tracking participants are shown in Table 5.1. Demographics for post assessment respondents are summarized in Table 5.2 (see Appendices A and B for the demographic details of all respondents and participants). 
Table 5.1: Demographic summary of eye-tracking participants.

\begin{tabular}{|l|r|r|}
\hline Age & Sólheimajökull & Pingvellir \\
\hline $20 s$ & 5 & 4 \\
\hline $30 s$ & 5 & 7 \\
\hline $40 s$ & 2 & 2 \\
\hline $60 s$ & 2 & 2 \\
\hline $60 s$ & 1 & 0 \\
\hline Gender & Sólheimajökull & Pingvellir \\
\hline M & 9 & 7 \\
\hline F & 6 & 8 \\
\hline Nationality & Sólheimajökull & Pingvellir \\
\hline Denmark & 1 & 0 \\
\hline UK & 1 & 1 \\
\hline USA & 5 & 9 \\
\hline Canada & 2 & 3 \\
\hline Germany & 2 & 0 \\
\hline Australia & 1 & 0 \\
\hline Czech Republic & 1 & 0 \\
\hline Netherlands & 1 & 0 \\
Belgium & 1 & 0 \\
\hline Ireland & 0 & 2 \\
\hline
\end{tabular}


Table 5.2: Demographic summary of survey respondents.

\begin{tabular}{|c|c|c|}
\hline Age & Sólheimajökull & Pingvellir \\
\hline $20 \mathrm{~s}$ & 4 & 11 \\
\hline $30 \mathrm{~s}$ & 9 & 10 \\
\hline $40 \mathrm{~s}$ & 5 & 2 \\
\hline $50 \mathrm{~s}$ & 6 & 5 \\
\hline $60 \mathrm{~s}$ & 6 & 6 \\
\hline $70 \mathrm{~s}$ & 4 & 1 \\
\hline Gender & Sólheimajökull & Pingvellir \\
\hline$M$ & 17 & 14 \\
\hline $\mathrm{F}$ & 18 & 21 \\
\hline Nationality & Sólheimajökull & Pingvellir \\
\hline France & 3 & 0 \\
\hline USA & 14 & 21 \\
\hline Canada & 4 & 3 \\
\hline Ireland & 3 & 0 \\
\hline Belgium & 1 & 0 \\
\hline Germany & 2 & 3 \\
\hline Denmark & 1 & 0 \\
\hline UK & 3 & 4 \\
\hline Spain & 1 & 0 \\
\hline Portugal & 1 & 0 \\
\hline Netherlands & 1 & 0 \\
\hline Switzerland & 1 & 0 \\
\hline Czech Republic & 0 & 1 \\
\hline Singapore & 0 & 1 \\
\hline Italy & 0 & 1 \\
\hline Scotland & 0 & 1 \\
\hline
\end{tabular}


To protect the identities of study participants, a naming scheme was used to refer to individual participants or respondents. Individuals who took part in eye-tracking trials were labeled as participants and assigned a numeric identifier based on the order in which the trail was completed. Similarly, individuals who only completed the assessment instrument were labeled as respondents and assigned a numerical identifier based on the order of completion (Appendix A). The labels respondent and participant are used throughout this chapter to differentiate between the sample populations.

\subsection{Site Development}

Upon initial analysis of the footpath data collected at the Sólheimajökull and Pingvellir study sites, obvious differences were observed in visitor behavior. Study results suggest that discrepancies in visitor behavior between the two sites are the result of site development. According to the Icelandic Tourism Board, Pingvellir National Park is the most visited tourism destination in Iceland. Due to its popularity, and its UNESCO world heritage status, considerable development has occurred at this site. In contrast, Sólheimajökull is farther from the capital city of Reykjavík and, thus, attracts significantly less visitors, annually. Due to these factors minimal infrastructure development has occurred at Sólheimajökull, which contributes to the sites authentic and natural environment.

\subsubsection{Pingvellir National Park}

Using the classification system outlined by Lau and McKercher (2006), the network of trails at bingvellir most closely resembles a complex neighborhood structure which serves multiple areas of interest and prevents major trail deviations (Figure 5.1); 
in comparison to the single point trail system present at Sólheimajökull, the complex neighborhood structure at Pingvellir branches off at various points of interest, but remains connected to a root trail. Trails at Pingvellir includes boardwalks, dirt paths, and gravel trails which are easily distinguished from the surrounding area. Points of interest at Pingvellir include water-filled fissures, historic landmarks, waterfalls, and diverse biology, each of which is served by the current trail structure. For example, Figure 5.2 shows one instance where a participant was documented distinguishing defined paths from a restricted area. In this particular moment, Participant 2 has dropped a receipt off of the trail; as the friend of the participant walks off the boardwalk to retrieve the receipt, Participant 2 was documented saying, "You're breaking the rules and I caught it on camera" (Participant 2, personal communication, 2017). What this indicates is that management signs at Pingvellir were clear and effective at communicating the restricted terrain, despite the fact that an individual was documented deviating from the boardwalk. This instance also supports the use of eye-tracking in assessing the development of ecotourism destinations as it shows the use of the technology to document effective development. 


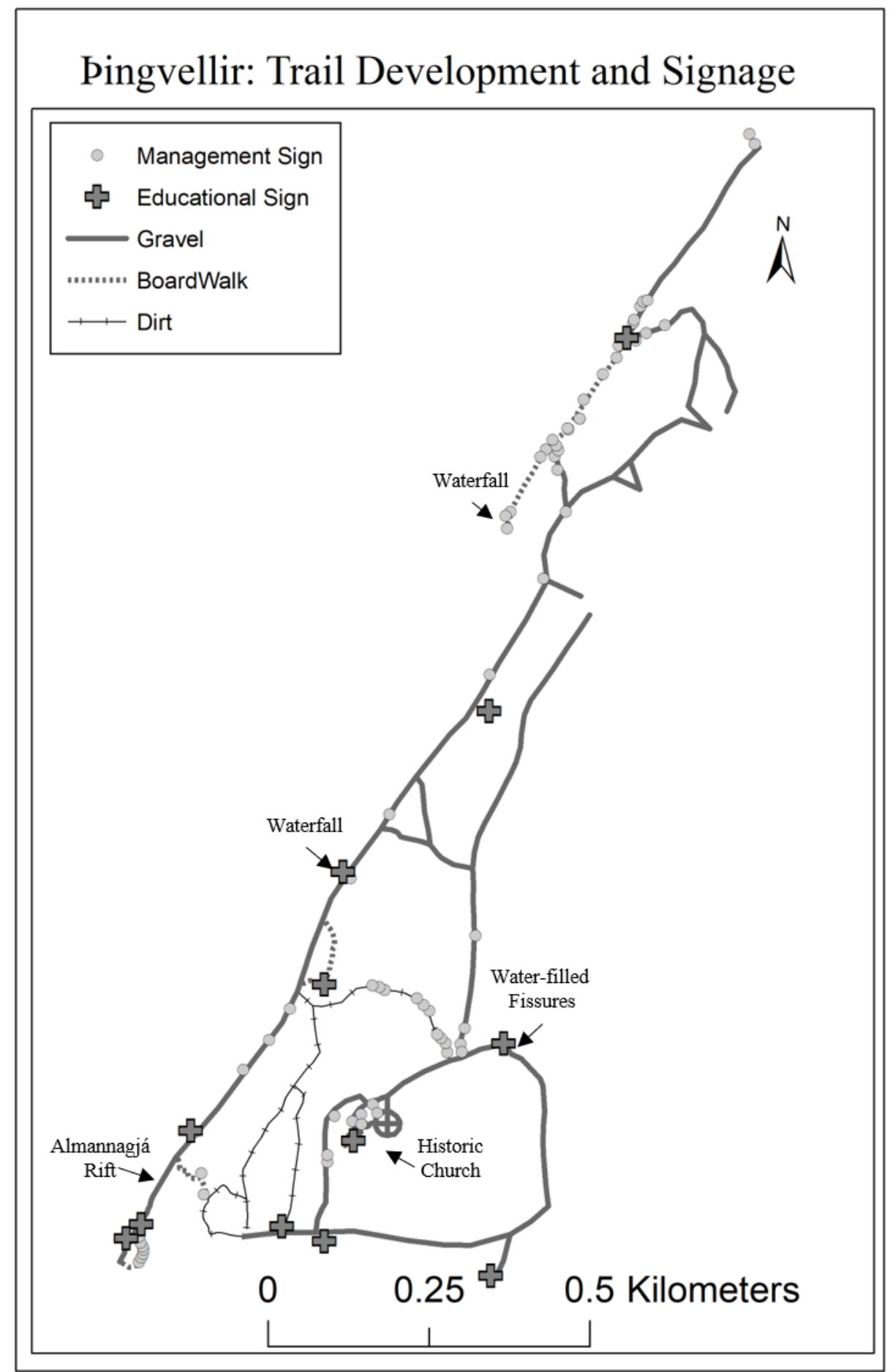

Figure 5.1: Distribution of signs and trail design at Pingvellir National Park (created by author). 


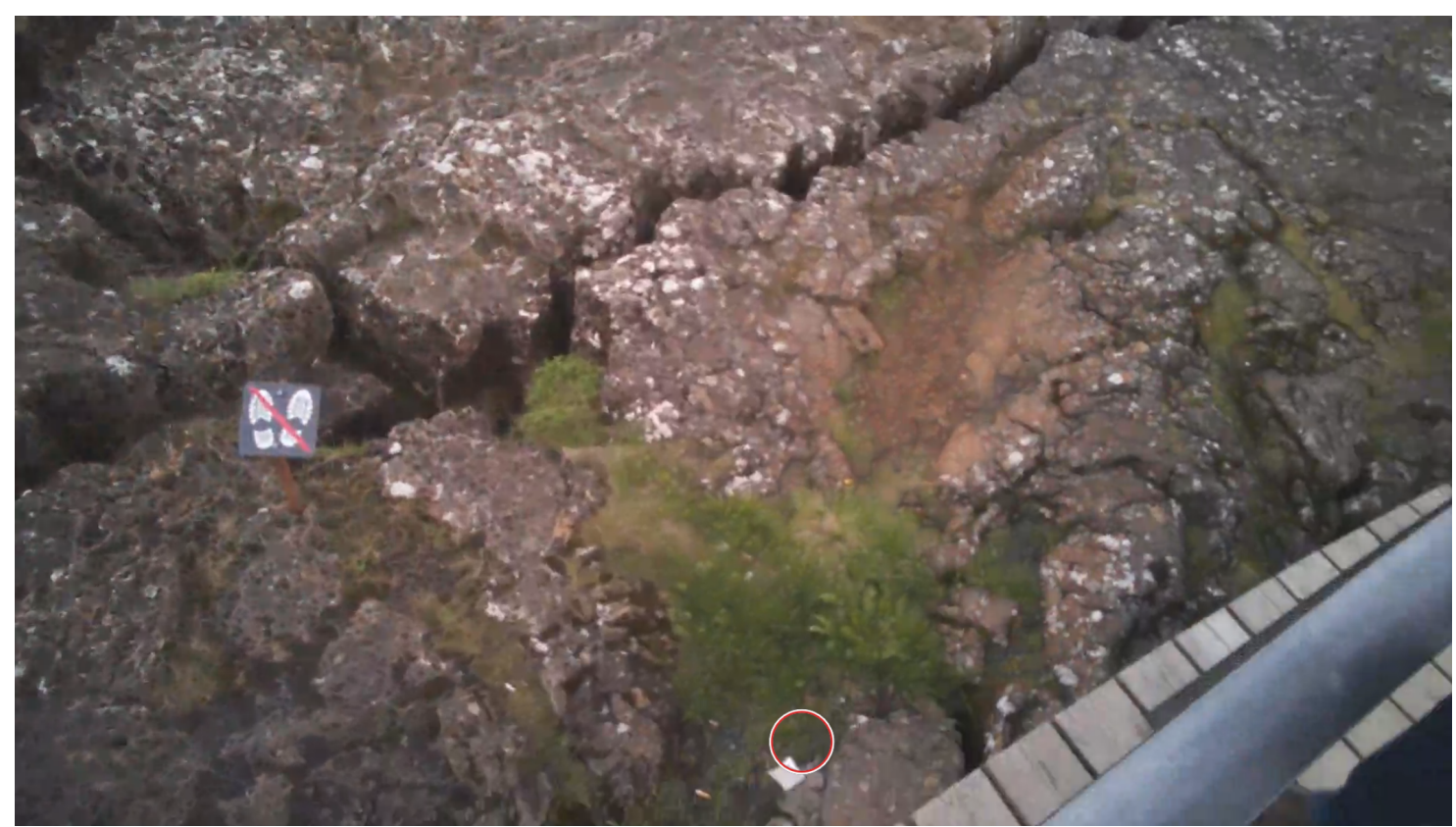

Figure 5.2: Participant 2 distinguishes defined trail from restricted area. Photo captured by author from eye-tracking video file.

In terms of interpretive material, pingvellir has informational signs distributed throughout the park at natural stopping points and areas of interest. In addition to these informational signs, a visitor's center, which hosts an array of multimedia interpretive material and interactive content, is also available to the public. All signs at Pingvellir are, however, not educational in nature; in fact, the number of signs which are aimed at decreasing unwanted visitor behavior vastly outnumber those aimed at educating visitors. These signs were documented using the Garmin Montana 680 GPS unit (see Figure 5.1). Based on the behavior observed in the eye-tracking trials, the presence of signs aimed at decreasing unwanted behavior throughout Pingvellir results in considerably less deviation from the trails of Pingvellir than at Sólheimajökull. The management signs at Pingvellir are easily understood visual cues which communicate to the diverse population that visits the area. In addition to management signs, certain areas 
of Pingvellir are roped off to reinforce the message of the signs and prevent visitor deviation from trails.

The well-defined and maintained trails at Pingvellir (Figure 5.3) allow participants to focus on their surroundings, as they do not have to focus their attention on the path ahead of them to prevent tripping; in comparison, participants are less aware of their surroundings and the interpretative material around them and are more focused on the rocky and somewhat unstable trails while walking at Sólheimajökull. For example, Figures 5.4 and 5.5 shows the attention of Participant 2 during a 20 -second segment of trail at Pingvellir; Figures 5.6 and 5.7 shows the attention of Participant 25 on a 20 -second segment of trail at Sólheimajökull. As documented using mobile eyetracking technology, trail development at Pingvellir leads to greater attention on a visitor's surroundings than at Sólheimajökull.

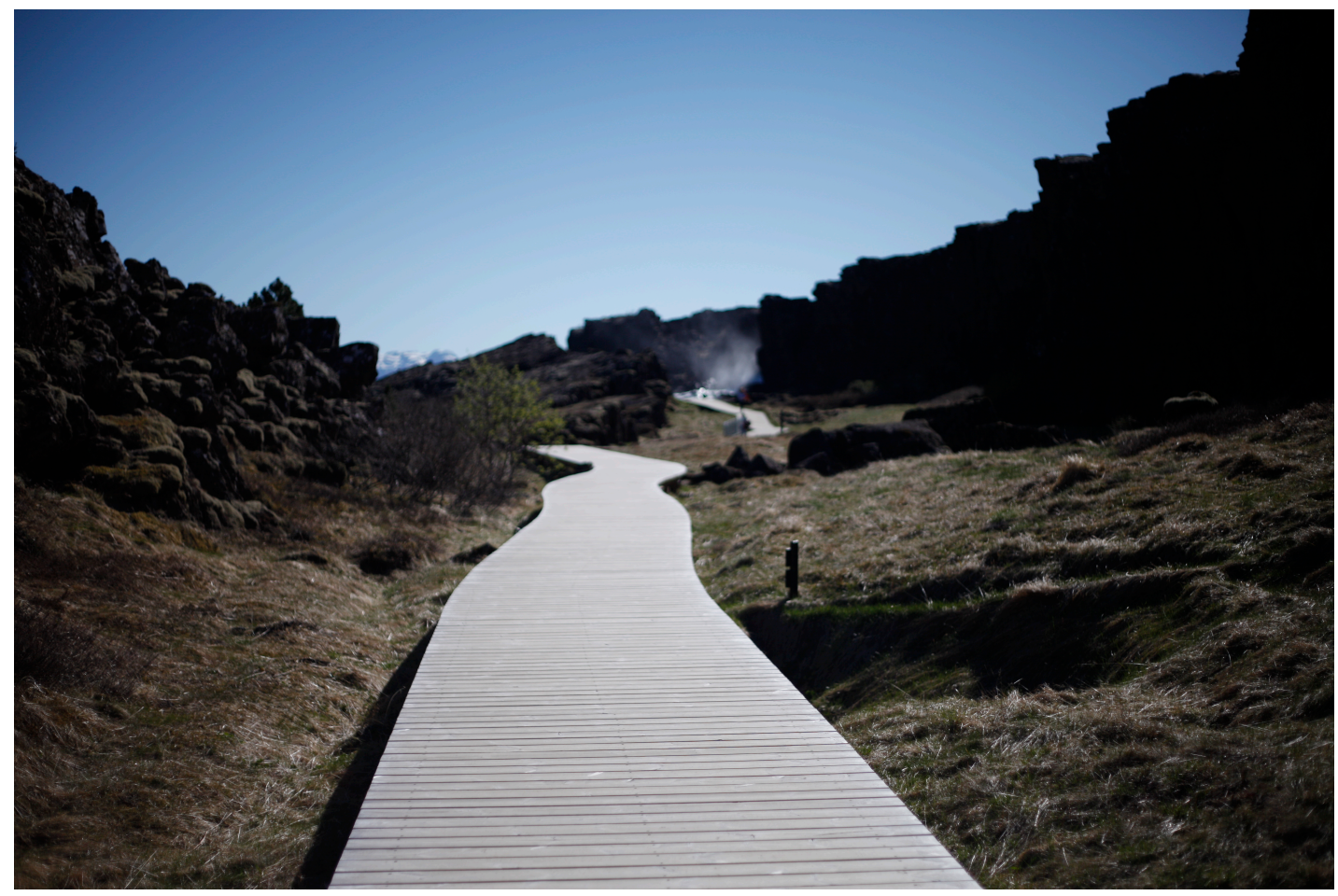

Figure 5.3: Boardwalk at Pingvellir National Park (photo by author). 


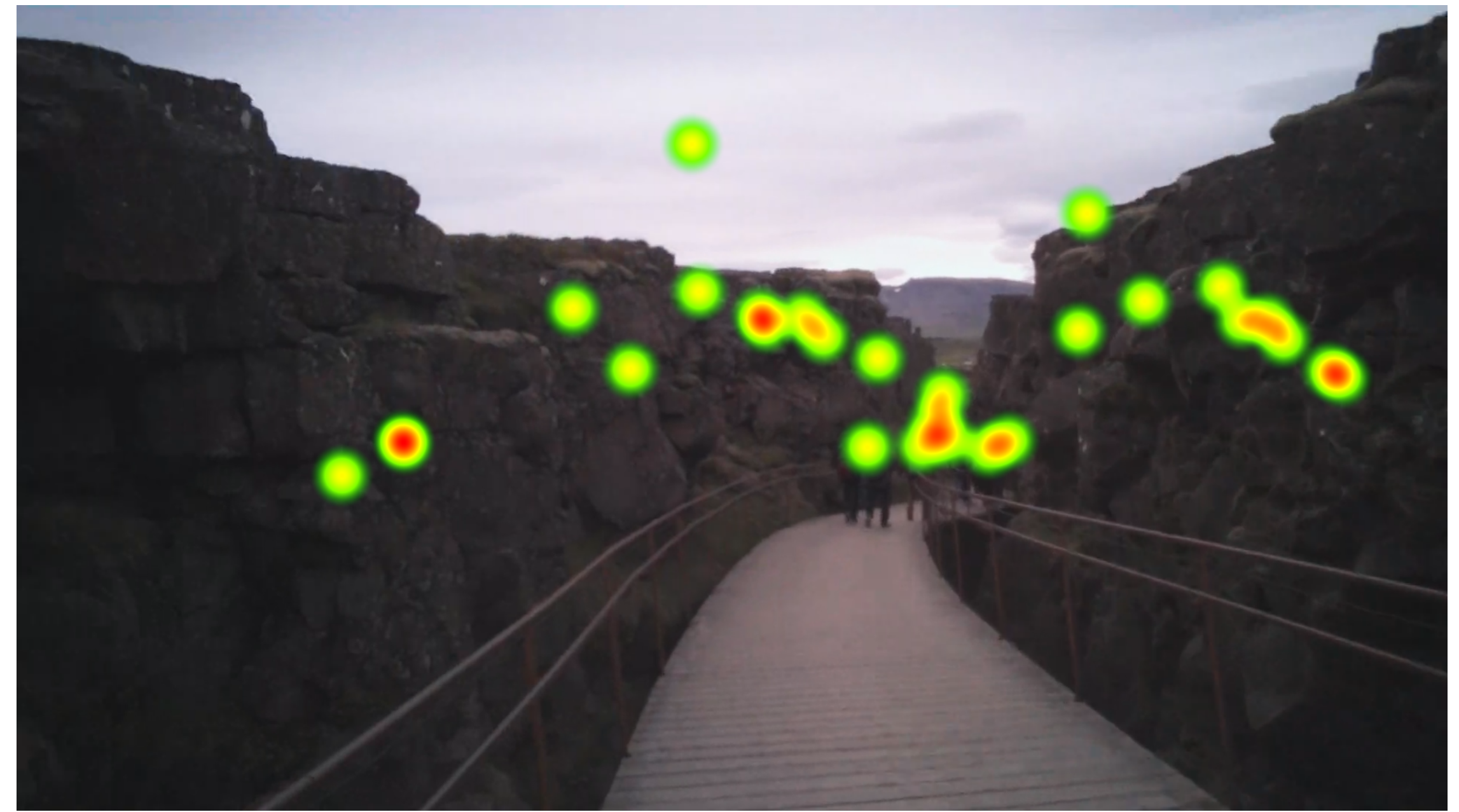

Figure 5.4: Attention path of Participant 2 walking on trail at Pingvellir (heat map). Photo generated by author from eye-tracking video file. 


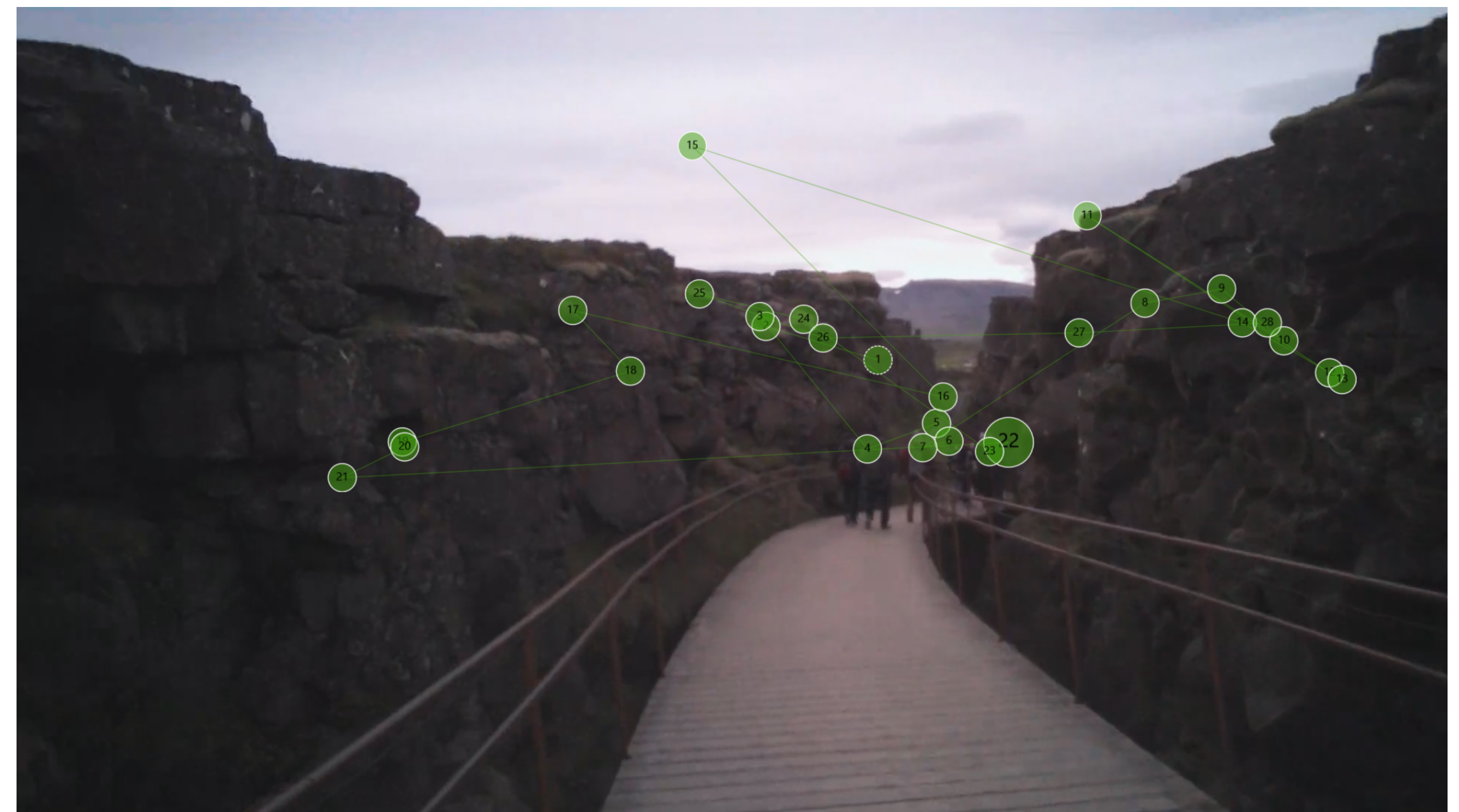

Figure 5.5: Attention path of Participant 2 walking on trail at Pingvellir (gaze plot). Lines indicate movement of eyes between fixation points. Order is indicated by the number shown in the circles. The size of the circle (fixation point) indicates time spent fixated on the point. Photo generated by author from eye-tracking video file. 


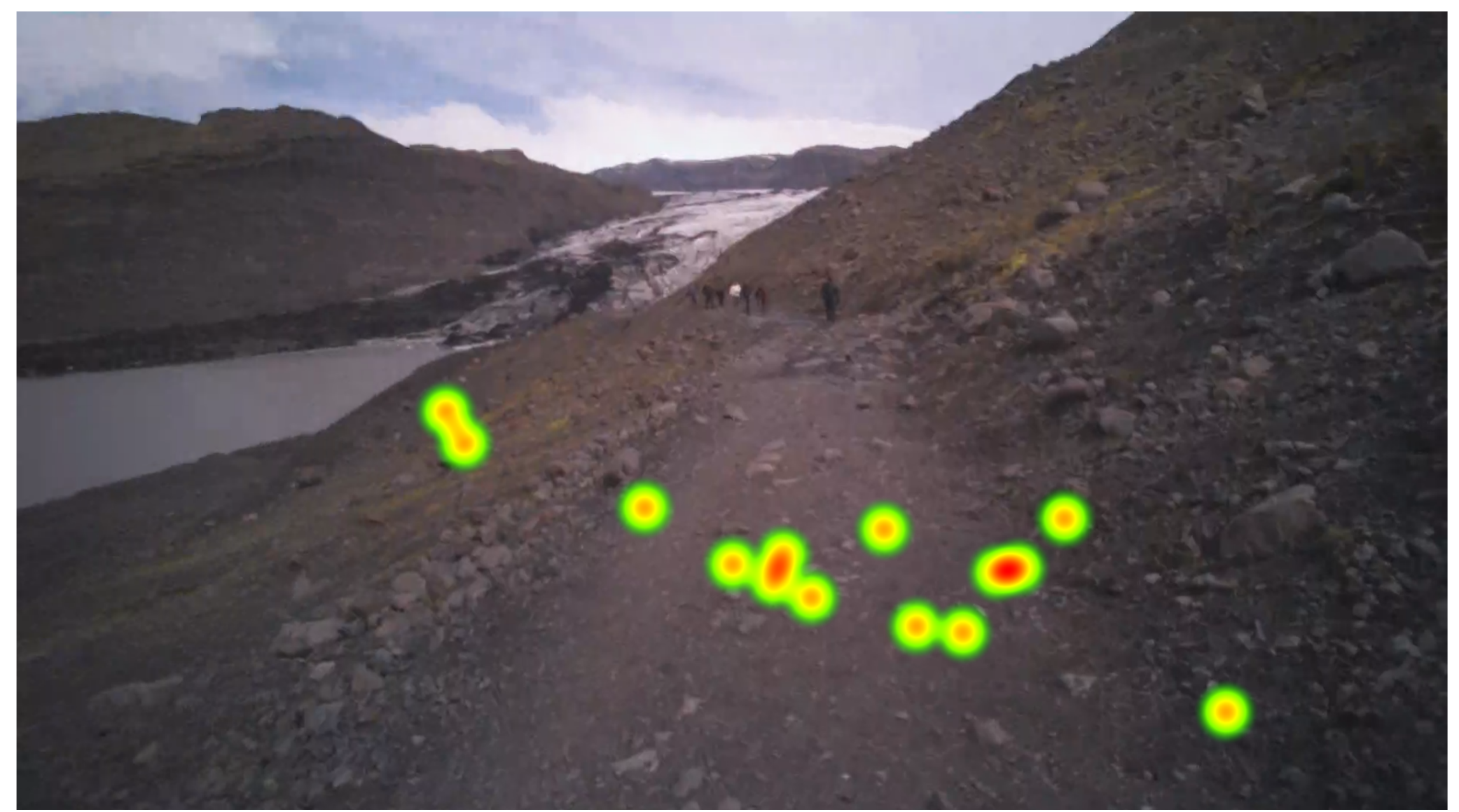

Figure 5.6: Attention path of Participant 25 while walking on trail at Sólheimajökull (heat map). Photo generated by author from eyetracking video file. 


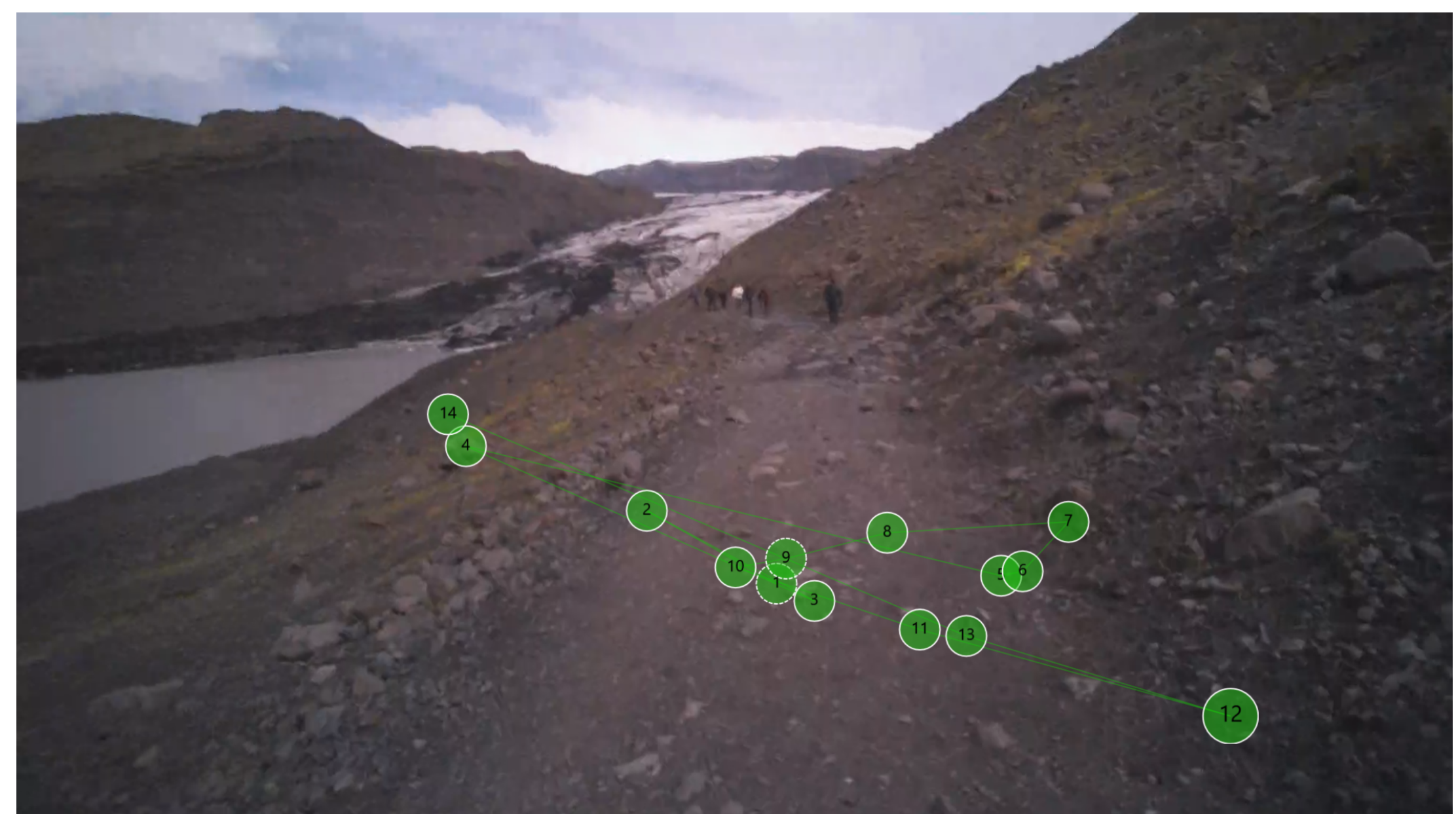

Figure 5.7: Attention path of Participant 25 while walking on trail at Sólheimajökull (gaze plot). Lines indicate movement of eyes between fixation points. Order is indicated by the number shown in the circles. The size of the circle (fixation point) indicates time spent fixated on the point. Photo generated by author from eye-tracking video file. 


\subsubsection{Sólheimajökull}

Using the classification systems outlined by Lau and McKercher (2006), Sólheimajökull uses a single point trail system, which serves only one point of interest for the entire area. At Sólheimajökull, a rocky trail (Figure 5.8) begins at the parking area and traverses the glaciers lateral moraine to a viewing spot approximately 300 meters from the glaciers current extent. The issue with the single point trail system at Sólheimajökull is that it serves only a single point of interest. In the case of Sólheimajökull, as observed in multiple mobile eye-tracking trial videos, visitors were observed deviating from trails to get closer to additional points of interest including the glacial lagoon, vegetation, and the glacier surface. Using mobile eye-tracking technology this study was able to identify common motivations amongst participants who deviated from the trail.

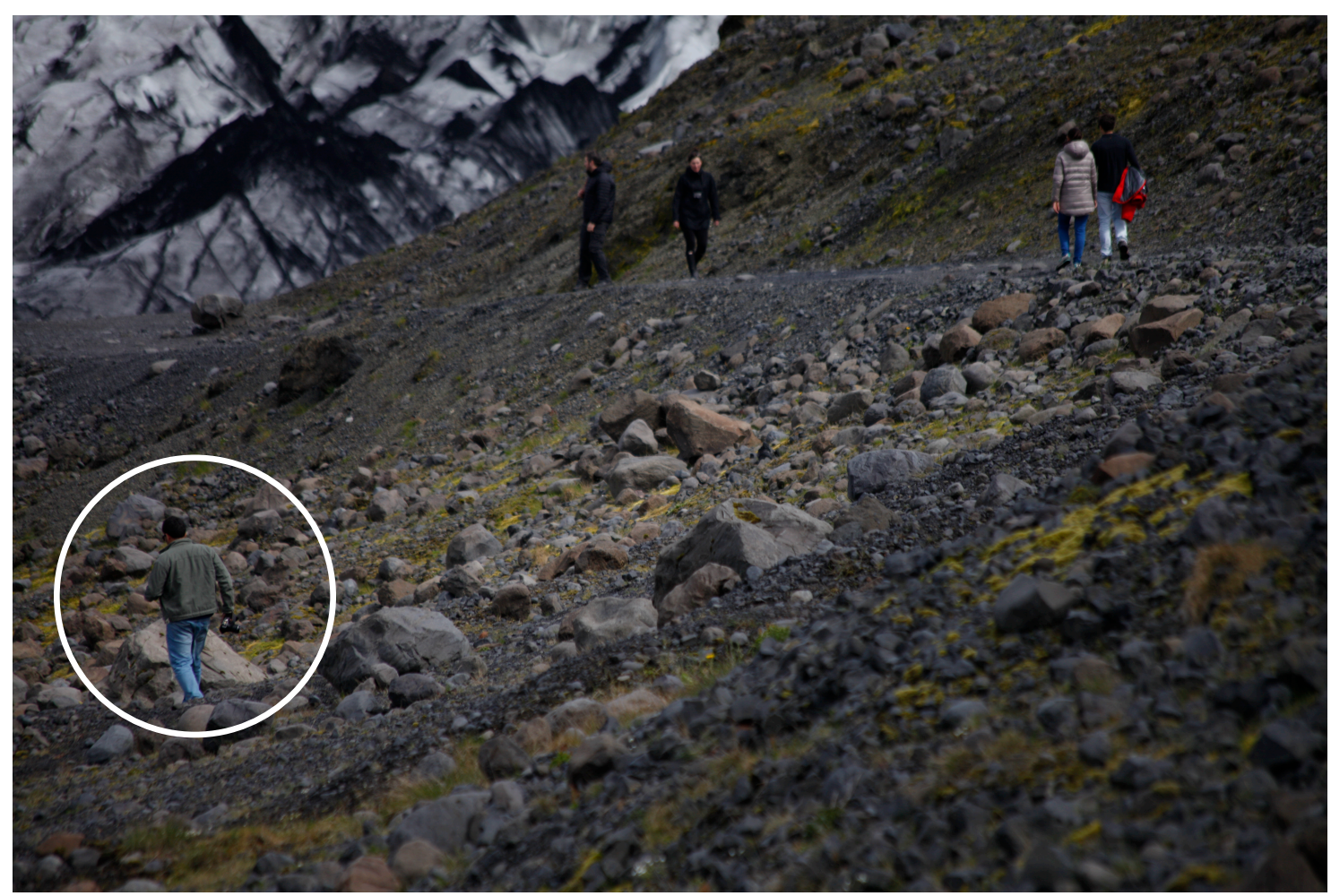

Figure 5.8: Visitor deviating from trail at Sólheimajökull (photo by author). 
Sólheimajökull has only three signs aimed at discouraging unwanted visitor behavior; a sign is posted at the entrance, the terminus of the trail, and the base of the glacier (Figure 5.9). The issue with this sign placement design is three-fold. First, if a visitor overlooks the first posted sign he or she may not be unaware they are not allowed to deviate from the trail in the area between the first and second sign. Secondly, the trail at Sólheimajökull is not well distinguished from the surrounding landscape; the trail is rocky and somewhat unstable and, as a result, many participants were observed focusing heavily on the trail ahead of them rather than their surrounding environment (see Figure 5.5); in short, the added distraction presented by the underdeveloped trail system at Sólheimajökull causes tourists to miss posted signage. Finally, the presence of an additional sign at the base of the glacial tongue suggests to visitors that they can approach it, despite the fact that the second sign indicates they are not to pass it. For example, Participant 26 was documented stating, "See I bet it is that yellow sign that we can't go past," referring to the sign at the base of the glacier (Figure 5.10). In some cases, visitors even believed that the second sign was out dated and no longer represents the end of the trail. For example, Participant 18 was documented saying, "There is a sign up there that says do not pass this point due to calving glacier, well that may have been so in 2007, but not now." What this suggests is that the presence of the third sign might reinforce the belief that the second sign is outdated and no longer valid. Due to these flaws in sign placement and trail development at Sólheimajökull, considerably greater deviation from trails was regularly observed at Sólheimajökull than at Pingvellir. Through analysis of the GPS data one is able to identify common areas of deviation 
amongst visitors; however, without the mobile eye-tracking data one would not be able to identify the misconceptions that arose due to improper placement of signs. 


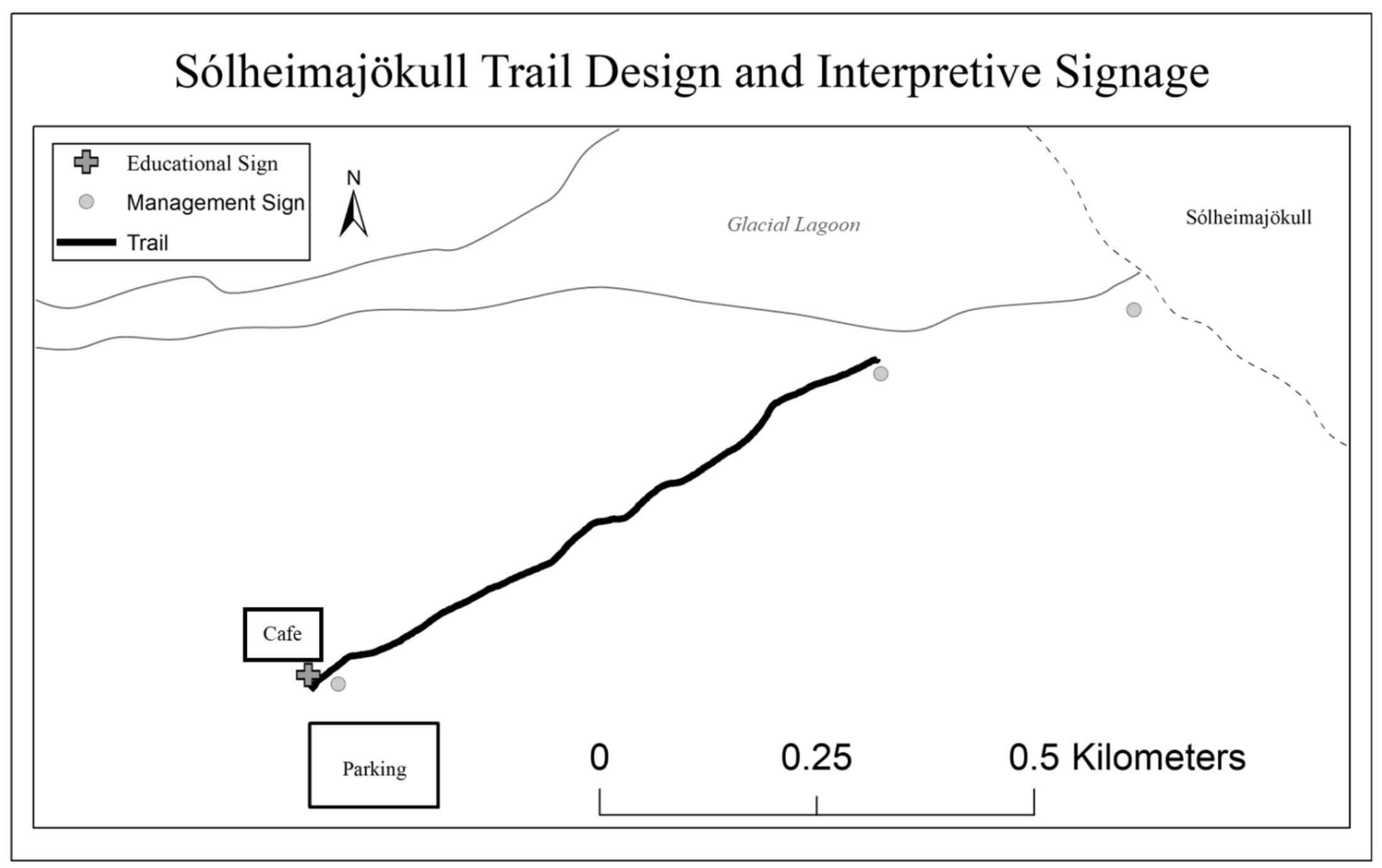

Figure 5.9: Sign distribution and trail design at Sólheimajökull (created by author). 


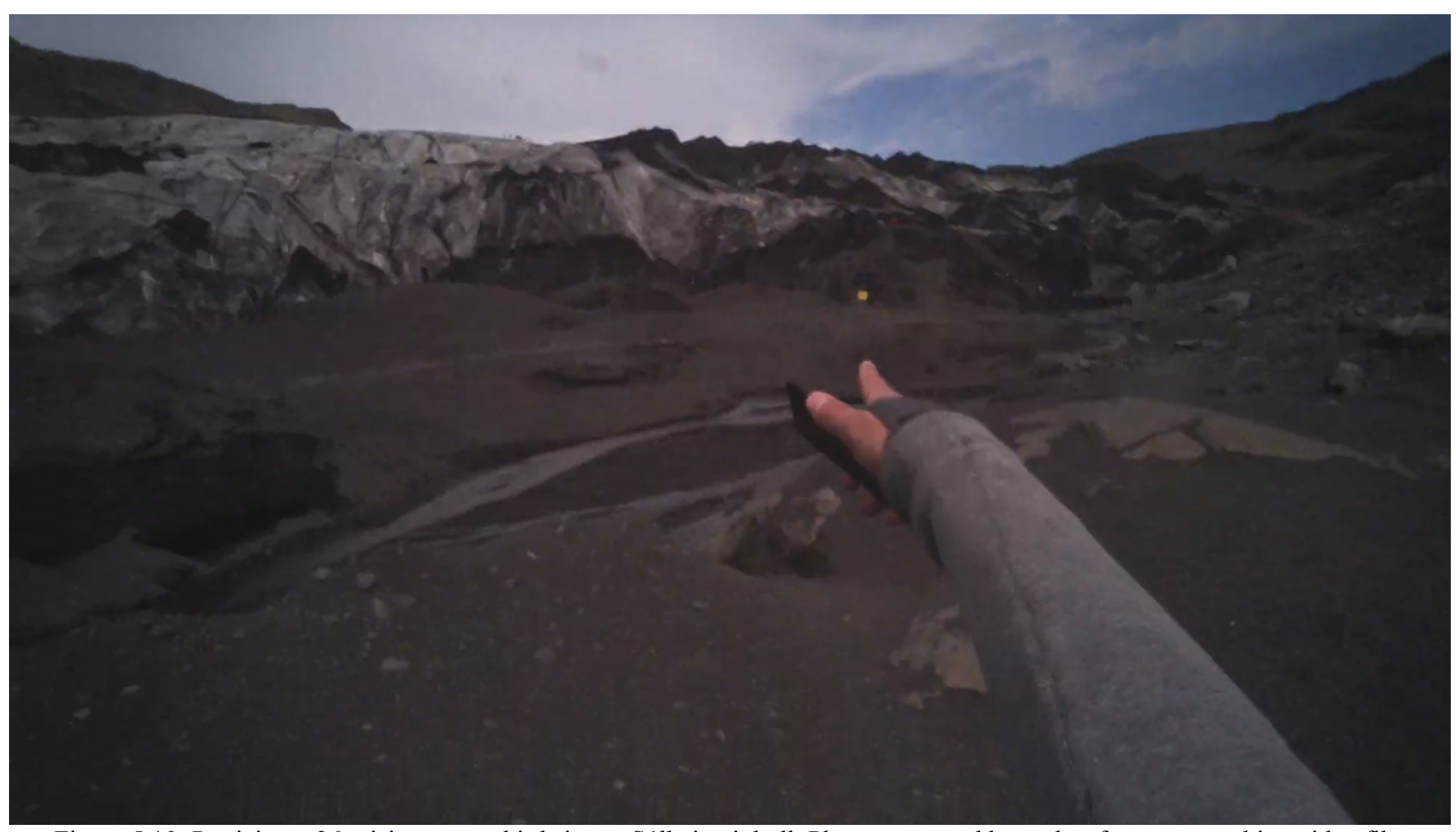

Figure 5.10: Participant 26 misinterprets third sign at Sólheimajökull. Photo generated by author from eye-tracking video file. 


\subsubsection{Combining GPS and Eye-Tracking Data for Site Development}

The use of eye-tracking data can produce valuable insights into visitor behavior and experience within a given environment. The addition of GPS data collection can support the findings made through analysis of eye-tracking data, while also allowing the researcher to identify specific areas of interest within an environment. As part of this study, the researcher collected reference data using a Garmin Montana 680 GPS handheld device; reference data included trails, signs, and points of interest and were used to generate trail maps for both Pingvellir and Sólheimajökul. The trail shapefile was then used to create a buffer of five meters, which allowed for trail deviations by eye-tracking participants to be identified. For data analysis purposes, two types of deviation were identified: minor deviation and major deviation. Minor deviations were characterized by extremely brief departures (less than 10 seconds) from trails with a rapid return to defined trails. Major deviations were characterized as blatant disregard for existing trails, with significant time (greater than 10 seconds) spent in undefined and undeveloped areas.

GPS data revealed that, collectively, Pingvellir participants spent $20.43 \%$ of their time deviating from trails. The median value for individual deviations was $18.29 \%$ of time spent deviating from trails. These deviation times appear high despite the existence of a highly developed trail system with barriers installed between trail and non-trail areas. When reviewing accompanying eye-tracking data for Pingvellir participants, much less trail deviation was observed than what the GPS unit recorded. This disagreement in data led the researcher to review the GPS data more closely and through this process, identify a significant geologic interference that occurred at the entrance of 
Pingvellir; Figures 5.11 and 5.12 show the area in which the GPS error was significant. As can be observed, natural and physical barriers exist within this particular location that prevent deviation from the trail. Additionally, after reviewing all 15 eye-tracking trials, not one participant was documented deviating in this area; the eye-tracking data allowed the research to confirm that only four minor deviations and one major deviation occurred at Pingvellir. Thus, eye-tracking and GPS data were both necessary to identify the true nature of visitor behavior at Pingvellir; one without the other would have led to a misinterpretation of data. After removing GPS points that fell within the region of GPS error, the median value of deviation at Pingvellir was slightly less at $17.49 \%$. This translates to 3.2 hours spent deviating from trails between participants out of a collective 18.5 hours. Provided that deviation at Pingvellir was not documented with great frequency the method used to calculate deviation is not entirely accurate, yet still serves to identify areas of interest within both study sites. Furthermore, the use of mobile eyetracking technology allowed for the verification of GPS results. Without the eyetracking data, this study would have misinterpreted and generalized the behavior of visitors based solely on the observations made using GPS footpath data. 


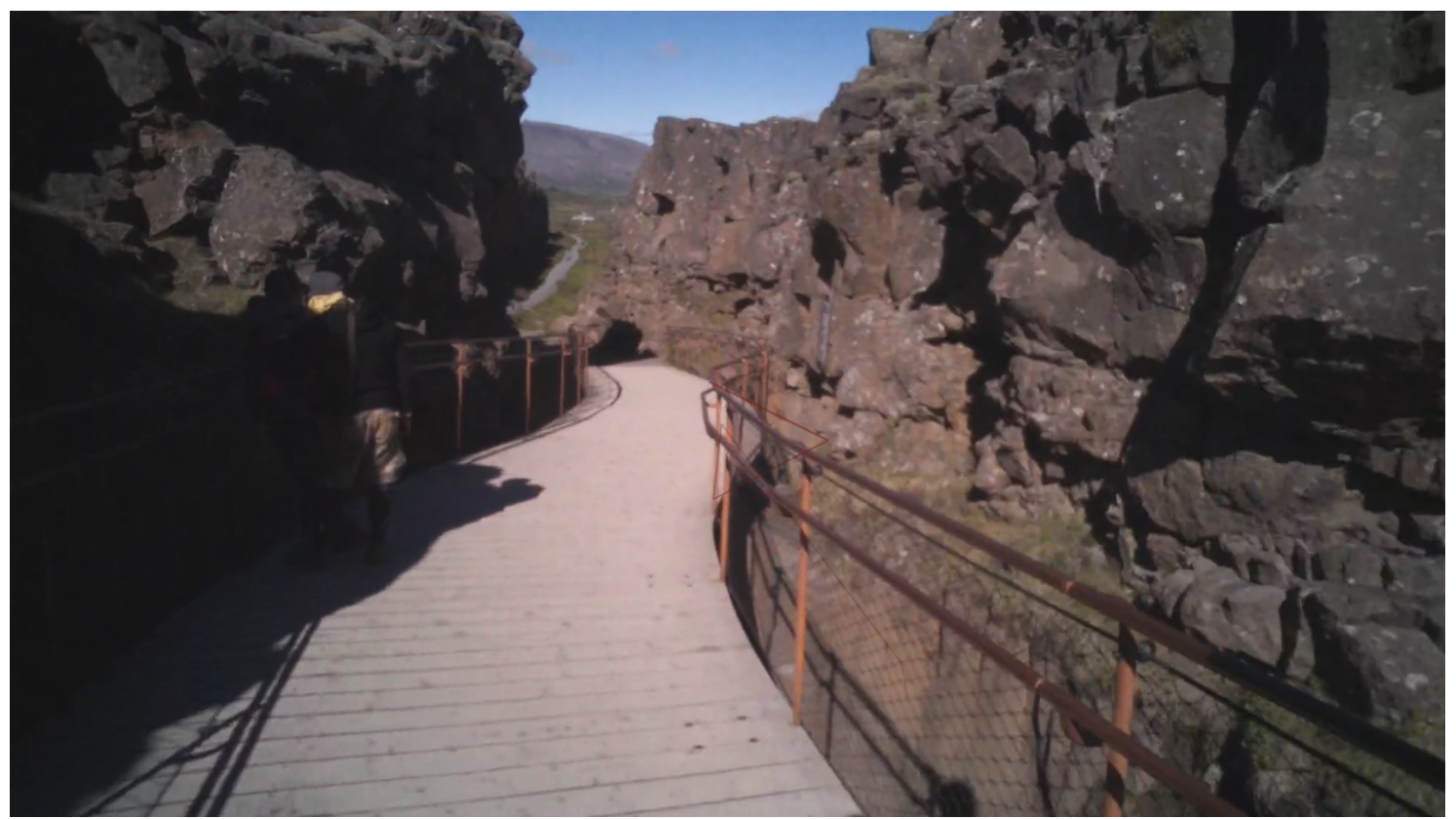

Figure 5.11: Location of significant GPS error at Pingvellir (photo) (photo by author). 


\section{Pingvellir: GPS Error}

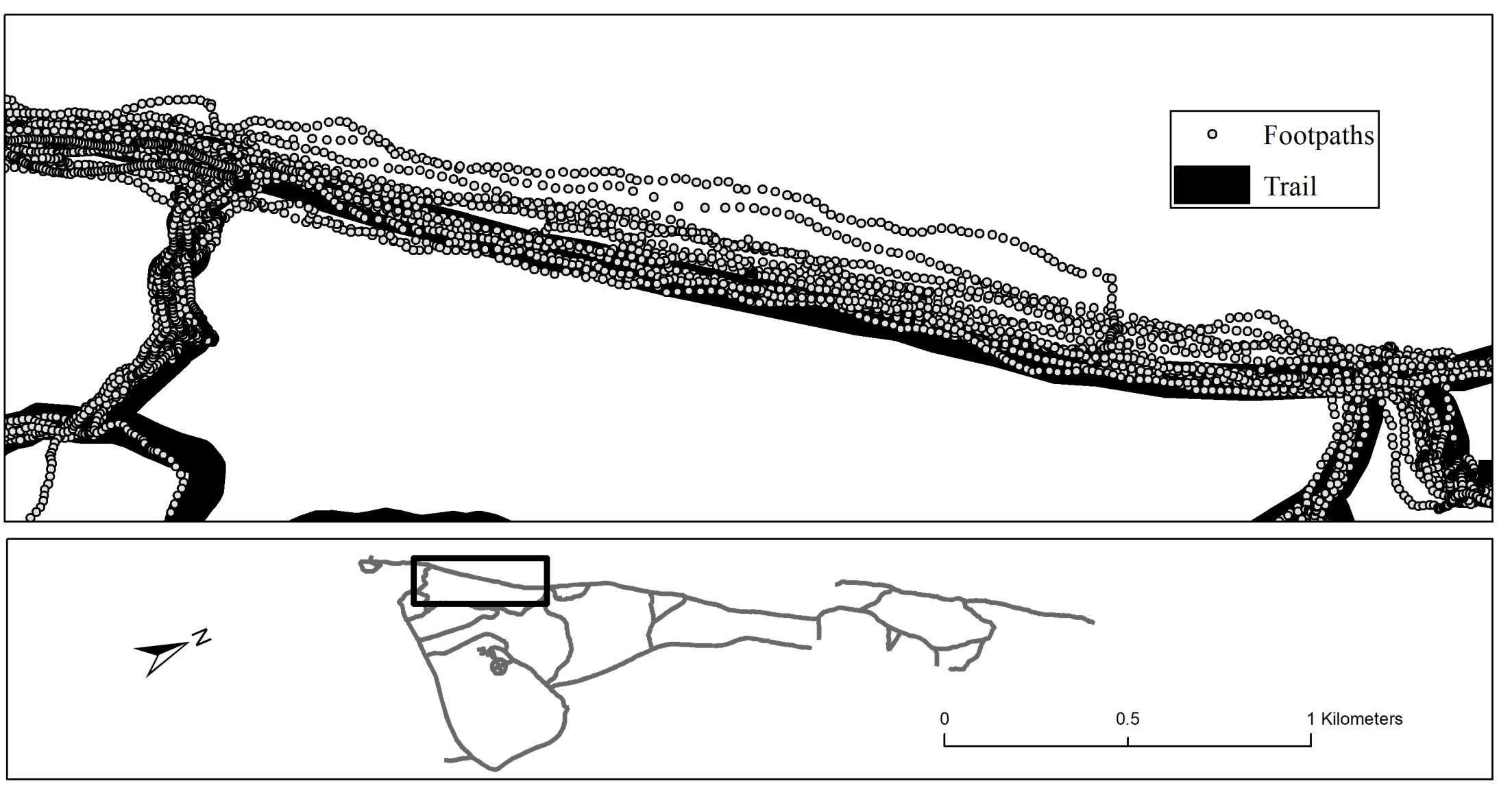

Figure 5.12: Location of significant GPS error at Pingvellir (map) (created by author). 
At Sólheimajökull, GPS data revealed that, collectively, participants spent $53.45 \%$ of their time deviating from the trail. The median value for individual deviations was $54.09 \%$ of time spent deviating from trails. This translate to 8.4 hours spent deviating from trails between participants out of a collective 15.7 hours. Unlike at Pingvellir, GPS data collection at Sólheimajökull experienced no interference; after observing eye-tracking trials for Sólheimajökull participants, the researcher concluded that GPS estimates of trail deviation corresponded closely with deviations observed during the eye-tracking video. GPS data revealed that 13 participants at Sólheimajökull majorly deviated from trails, which, through the evaluation of eye-tracking video, can be attributed to the lack of trail development and barriers. Together, GPS and eye-tracking data reveal that trail deviations at Sólheimajökull and Pingvellir are perpetuated by differences in trail and site development; specifically, the lower rate of deviation and observed participant behavior at Pingvellir suggest that the area has in place more effective strategies for managing tourist behavior than at Sólheimajökull.

In addition to highlighting differences in trail deviation between the two study sites, GPS data and eye-tracking video were also useful in determining trends in visitor behavior within the individual sites. Figures 5.13 and 5.14 show the density of participant footpaths within the two study areas. Using the results of the kernel density estimation, points of interest were identified, which led to closer analysis of eye-tracking trial data when visitors approached these specific locations. For example, many Sólheimajökull participants deviated near the trail's second management sign, at which point tourists are discouraged from getting any closer to the glacier. The researcher reviewed eye-tracking files and confirmed 13 of the 15 participants at Sólheimajökull 
deviated past the second management sign; 12 of the 13 deviating participants acknowledged the sign and deliberately disobeyed. Collectively, these findings suggest GPS and eye-tracking trials used together at Sólheimajökull can be used to inform the development and placement of signs that will more effectively influence visitor behavior. This is discussed in more detail in the section 5.2.3, wherein documented influences on visitor behavior are highlighted. 


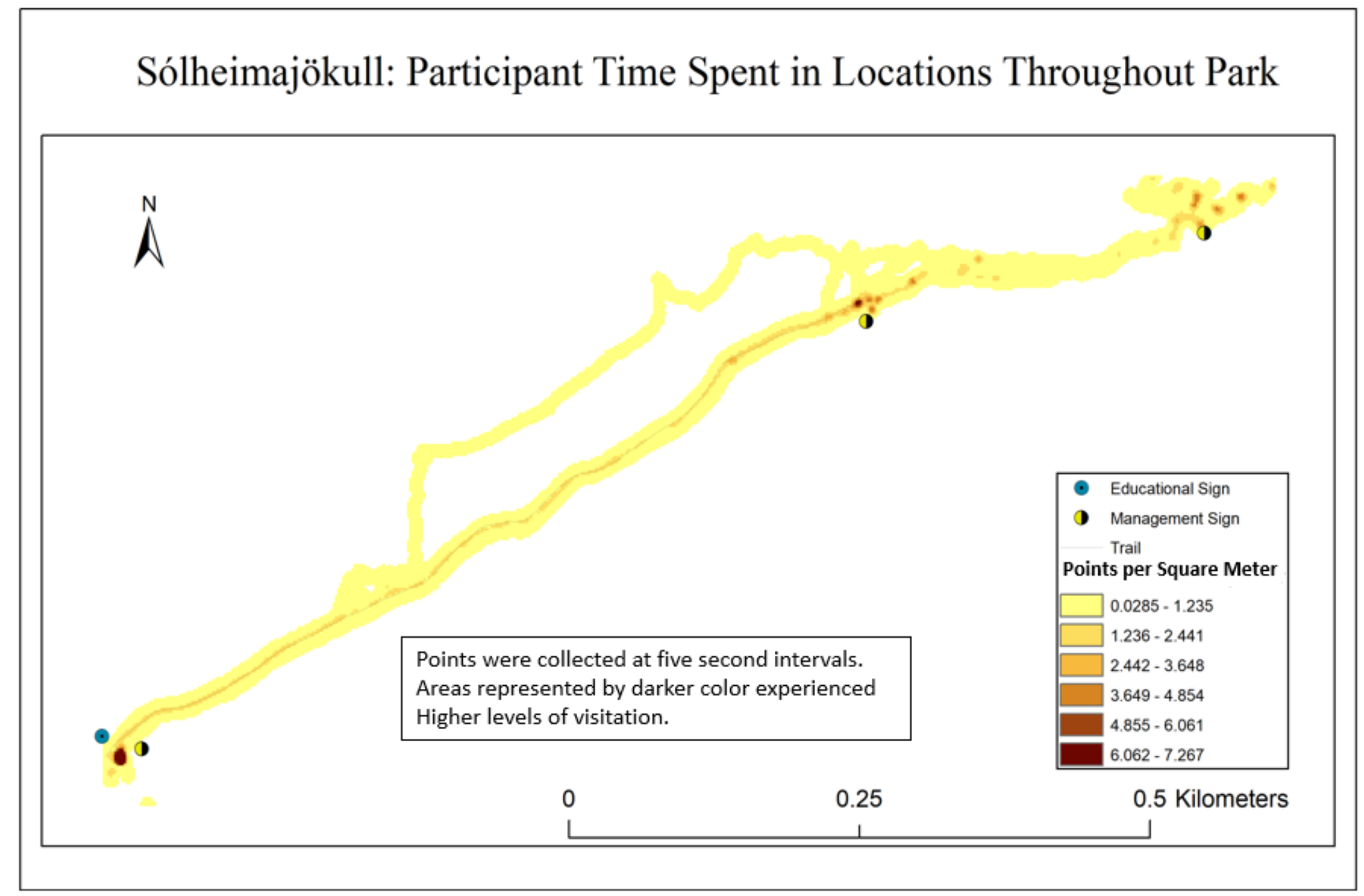

Figure 5.13: Visitor hot spots at Sólheimajökull (created by author). 


\section{Pingvellir: Participant Time Spent in Locations Throughout Park}
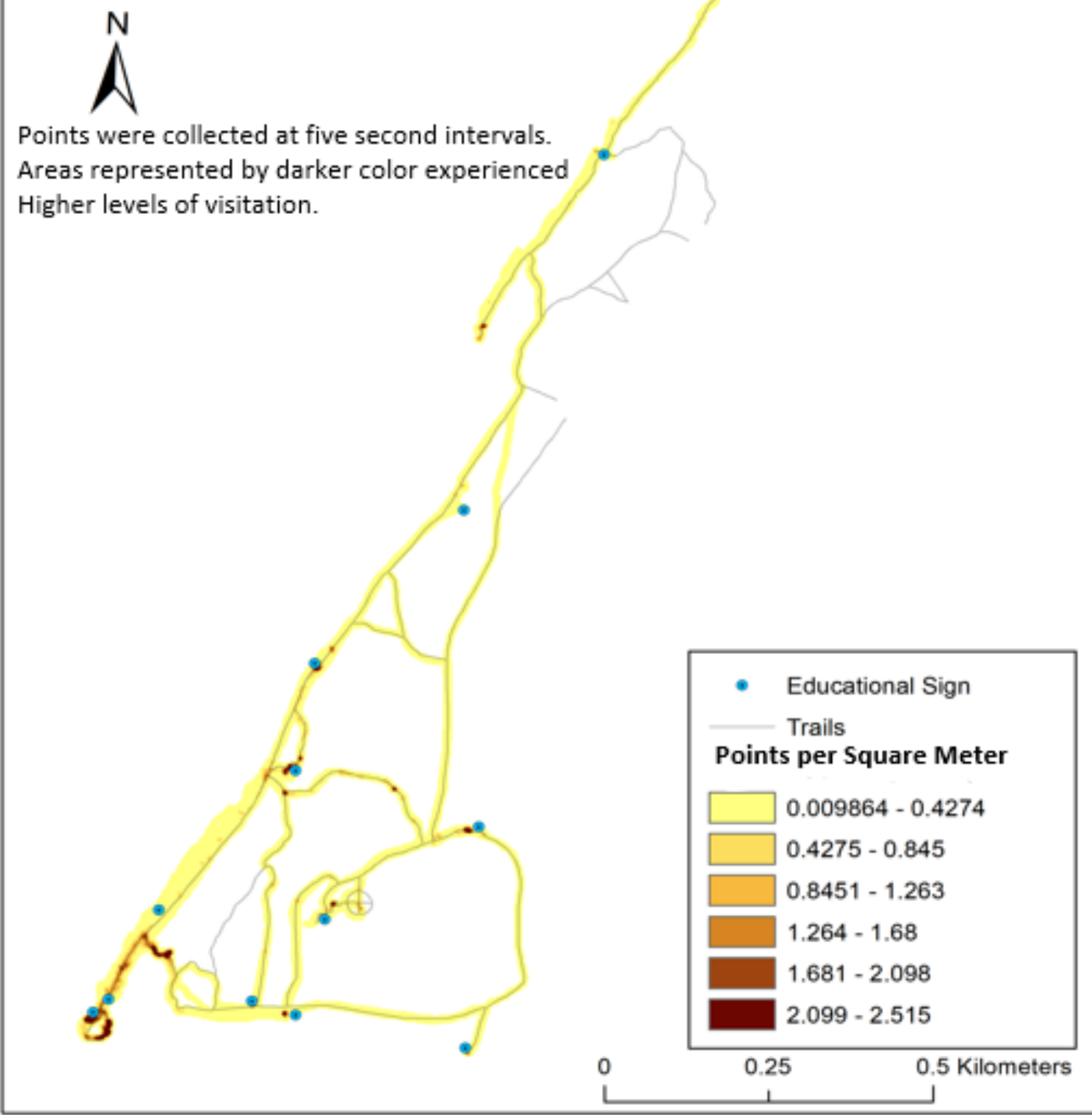

Figure 5.14: Visitor hot spots at Pingvellir (created by author).

In comparison to Sólheimajökull, GPS and eye-tracking data suggest that deviation at Pingvellir occurred much less frequently and, when it did occur, it was 
considerably less impactful to the landscape. In the areas where deviation occurred, eyetracking data can be reviewed to suggest what may have caused the deviation. In one instance, Participant 14 deviates from the paved trail to traverse a dirt path through an open field; this trail was marked as restricted access. By analyzing the GPS data, it is observed that there is only one sign posted at one end of the trail; thus, any visitor who may approach the trail on the opposite end will not be aware that the trail is no longer in use (Figure 5.15).

While deviation was not a major issue at Pingvellir, certain areas remain underdeveloped based on trends in visitor behavior. For example, multiple locations exist at Pingvellir where visitors are spending lots of time, yet no educational signs exist in these areas. After reviewing the eye-tracking data, one is able to determine what point of interest is causing visitors to stop in these locations so that interpretive material may be developed for future visitors. For example, Figure 5.16 shows one area of Pingvellir which had considerable visitation, yet possesses no interpretive material. Walking farther into the Park from the initial overlook at the entrance, the area represented in Figure 5.16 is a secondary overlook for the Pingvellir valley. The location would be served better by interpretive material that discusses the lava flows visible just off the trail, as well as the historical church and Lögberg in the distance. The Pingvellir valley possesses an impressive network of trails that guides visitors to various points of interest and interpretive signs; however, not a single participant was observed having made it to every interpretive sign in Pingvellir. Participants 1 and 15 did not venture to the second overlook shown in Figure 5.16. Participant 11 did not venture past the first overlook area. Every participant was, however, documented stopping at the first overlook. With 
that said, emphasis should be placed on presentation of interpretive material within the underserved areas in order to reach a wider audience. 


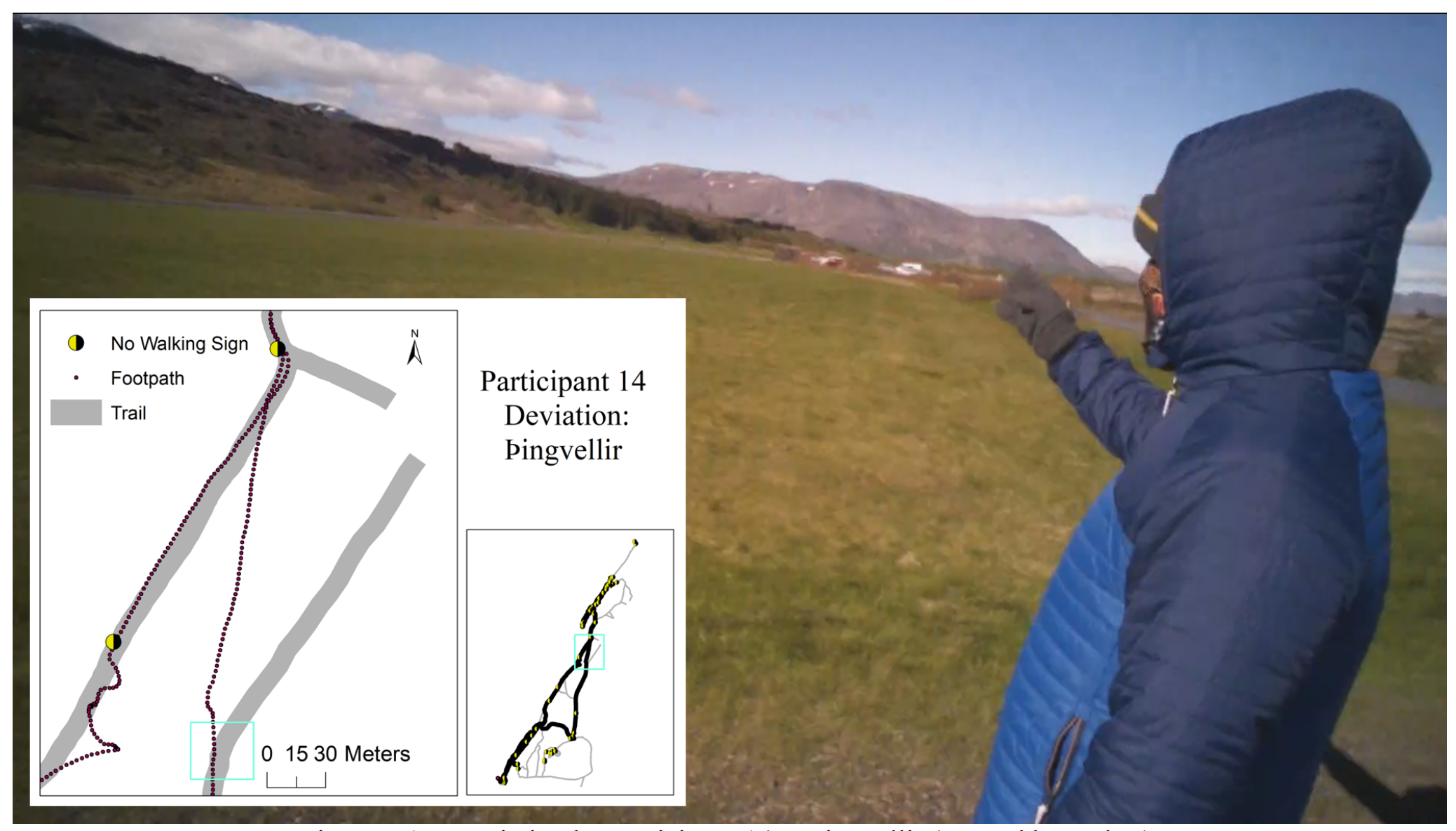

Figure 5.15: Deviation by Participant 14 at Pingvellir (created by author). 


\section{Pingvellir: Participant Time Spent in Locations Throughout Park}

Points were collected at five second intervals. Areas represented by darker color experienced Higher levels of visitation.

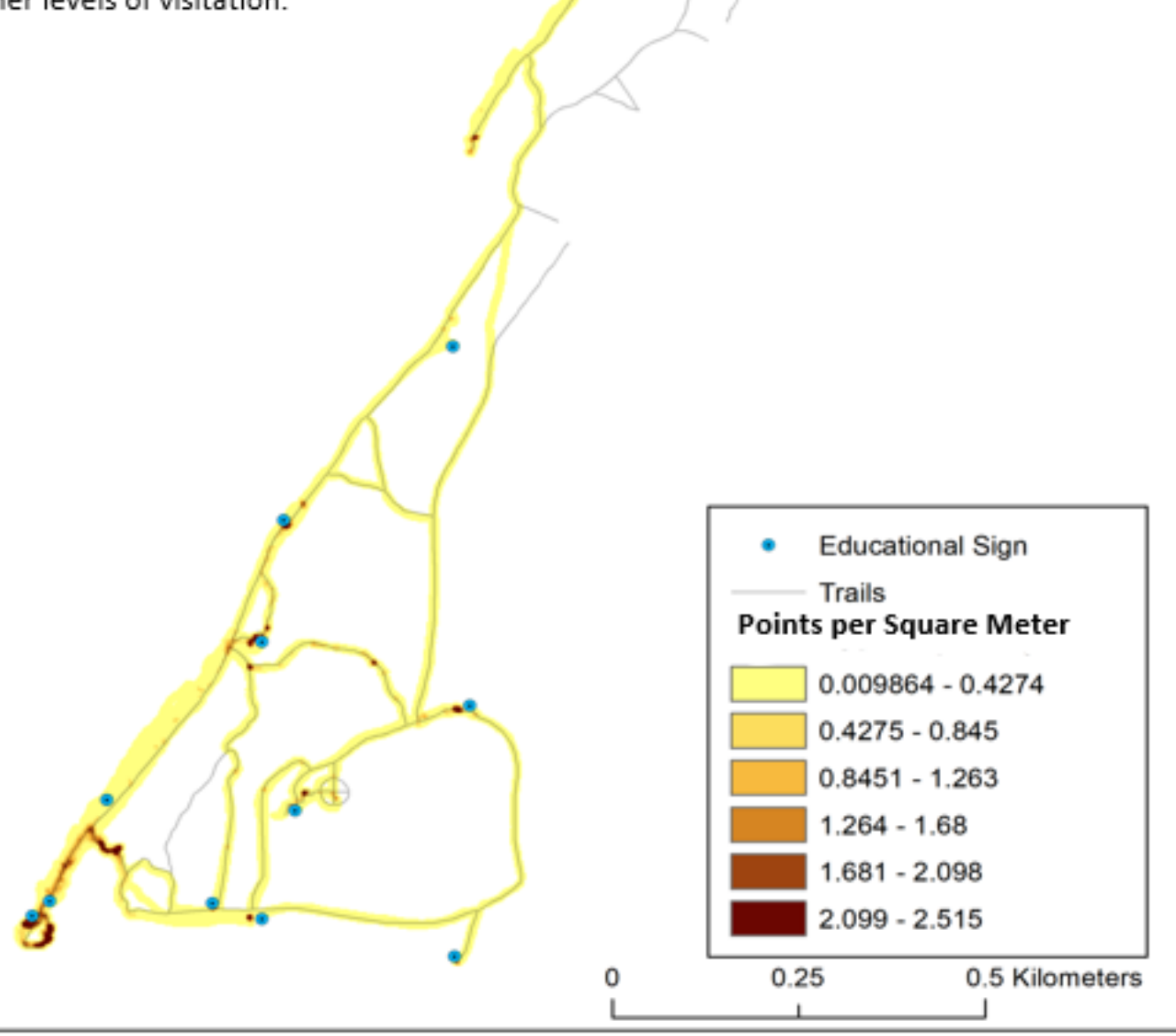

Figure 5.16: Example location of visitor interest at Pingvellir (created by author). 


\subsection{Tourist Expectations and Behavior}

\subsubsection{Visitor Expectations and Experiences}

At each study site, 50 individuals completed post-assessments after visiting the area. Of the 50 individuals that completed the assessments, 15 were also eye-tracking participants. Altogether, analysis of post-assessments provided insight into visitor expectations and experience within the two study sites.

Slight variations in assessment responses were documented between the two study sites. Figure 5.17 shows the distribution of answers for Likert-scale statements; Tables 5.1 and 5.2 provide a breakdown of the answers to the open response portions of the post assessment. At Pingvellir, visitors suggest that they learned about both the culture and geology of the area during their visit. In addition, the survey data suggest that information in signs was easily understood. Based on these responses, one would expect to observe considerable interaction with interpretive signs and material throughout Pingvellir. While this was the case, complexity of signs was commonly listed as an area of improvement in the open response section of the post-assessment. Through the design of less complex signs and, subsequently, engagement with signs, education, could be increased amongst future visitors. Furthermore, as suggested by the survey data, visitors overwhelmingly agree that the presence of trails and signs influenced their behavior while at Pingvellir. Even more profound was visitor's agreement with the statement that trails, signs, and/or restricted areas are appropriate tools to decrease damage to the environment in ecotourism destinations; thus, visitors seem to agree that restricting access to portions of Icelandic nature is an appropriate approach to prevent environmental degradation. Based on these survey data, the assumption can be made that 
the level of development that has occurred at Pingvellir does not negatively impact visitor experience, but may still need improvement to protect the site's natural features and maintain the safety of the visitors. 


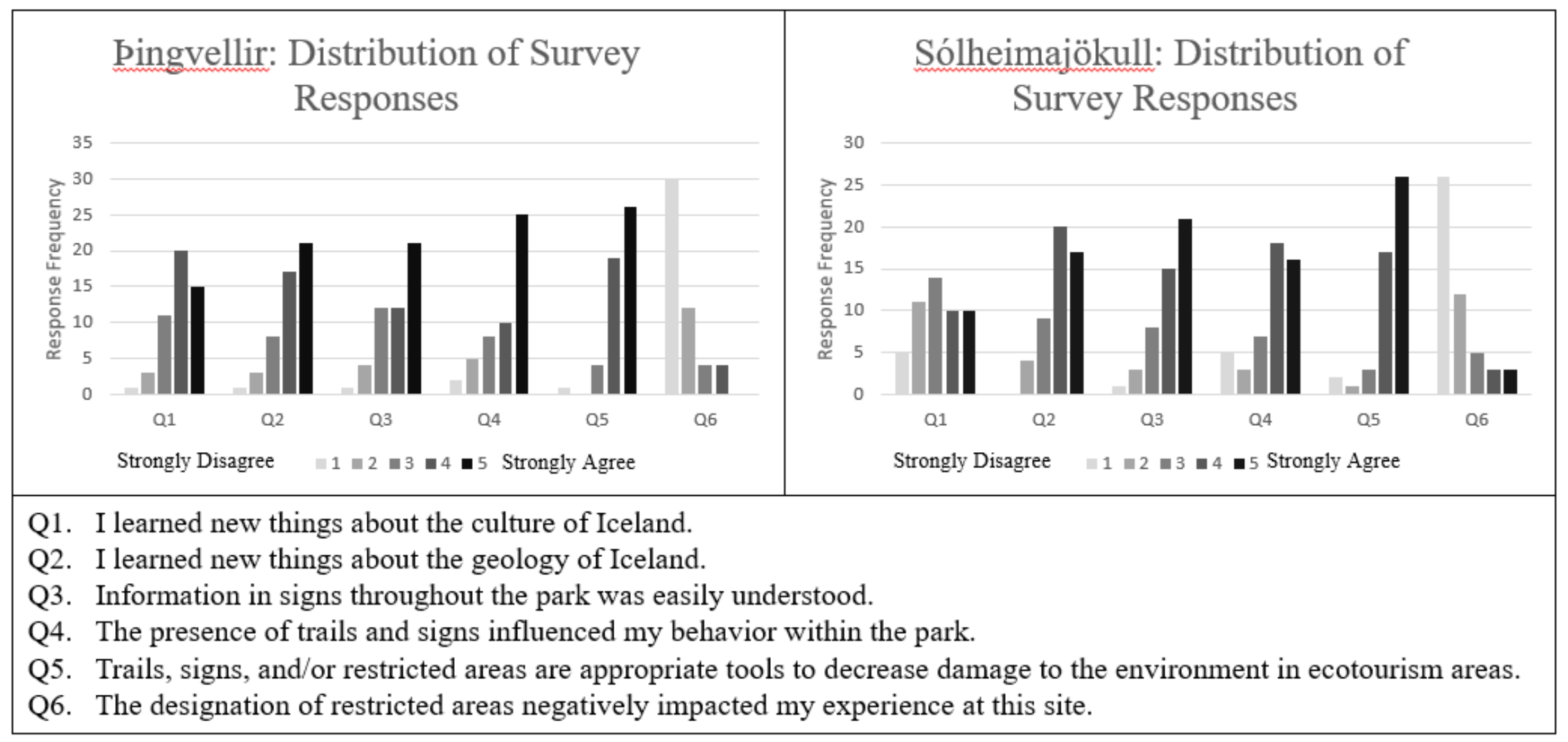

Figure 5.17: Distribution of Likert scale responses (created by author). 
Table 5.1: Breakdown of post-assessment responses (Sólheimajökull).

\begin{tabular}{|c|c|c|c|c|}
\hline \multicolumn{5}{|c|}{ Sólheimajökull Survey Responses } \\
\hline $\begin{array}{l}\text { Did you read the informa } \\
\text { you read them fully? Why }\end{array}$ & & & & \\
\hline Yes & 4 & 18 & 33 & \multirow{2}{*}{$\begin{array}{l}\text { Reasons stated for reading signs fully included safety, interest, knowledge to prevent } \\
\text { damaging the environment, short signs were not a time burden }\end{array}$} \\
\hline Yes with explanation & & 6 & 33 & \\
\hline Partially & 1 & 2 & 12 & \multirow{2}{*}{$\begin{array}{l}\text { Common reasons include that participants group had moved on, language was not written } \\
\text { in native tounge, to long / time, and previous experience at glaciers }\end{array}$} \\
\hline Partially with explanation & 3 & 7 & 13 & \\
\hline No & 1 & 2 & & \multirow[t]{2}{*}{ Did not go up far enough } \\
\hline No with explanation & 1 & 0 & 4 & \\
\hline \multicolumn{5}{|c|}{ Why did you visit this area today? } \\
\hline Guidebook & 2 & 5 & 7 & \\
\hline Part of tour & 1 & 7 & 8 & \\
\hline Beauty & 1 & 1 & 2 & \\
\hline Last chance & 1 & 0 & 1 & \\
\hline See a glacier & 5 & 12 & 17 & \\
\hline on the way / passing by & 6 & 4 & 10 & \\
\hline Nature & 1 & 0 & 1 & \\
\hline touch glacier & 0 & 2 & 2 & \\
\hline \multicolumn{5}{|c|}{$\begin{array}{l}\text { Did your experience meet your expectations? If } \\
\text { not what changes could be made to improve }\end{array}$} \\
\hline Yes & 9 & 30 & \multirow{2}{*}{43} & \multirow{2}{*}{$\begin{array}{l}\text { Explanations included the cleanliness of the sight, the sight, and that it was user } \\
\text { friendsly. Visitors also suggested that there could be more signs and less people ut }\end{array}$} \\
\hline Yes with explanation & 2 & 2 & & \\
\hline No & 0 & 0 & \multirow{2}{*}{6} & \multirow{2}{*}{$\begin{array}{l}\text { Too many people, could use more restrooms, thought there would be more ice, wanted to } \\
\text { go further }\end{array}$} \\
\hline No with explanation & 4 & 2 & & \\
\hline
\end{tabular}


Table 5.2: Breakdown of post-assessment responses (Pingvellir).

\begin{tabular}{|c|c|c|c|c|}
\hline \multicolumn{5}{|l|}{ Pingvellir Survey Responses } \\
\hline \multicolumn{5}{|l|}{$\begin{array}{l}\text { Did you read the informational signs? If } \\
\text { so, did you read them fully? Why or why } \\
\text { not? }\end{array}$} \\
\hline Yes & 0 & 11 & \multirow{2}{*}{32} & \multirow{2}{*}{$\begin{array}{l}\text { Responses included to learn, to know where to go, to know why it's a tourist hotspot, and to know how not to make a } \\
\text { mistake. One participant suggested more frequent shorter signs but still read all signs. }\end{array}$} \\
\hline Yes with explanation & 6 & 15 & & \\
\hline Partially & 3 & 0 & \multirow{2}{*}{15} & \multirow{2}{*}{$\begin{array}{l}\text { Responses included: Skipped if could not easily find english segments, wanted more time for walking, chose preffered } \\
\text { info, information provided was not what they were looking for, prior knowledge before visiting. One participant also }\end{array}$} \\
\hline Partially with explanation & 5 & 7 & & \\
\hline No & 1 & 0 & \multirow{2}{*}{3} & \multirow[t]{2}{*}{ no time, part of tour } \\
\hline No with explanation & 0 & 2 & & \\
\hline \multicolumn{5}{|l|}{ Why did you visit this area today? } \\
\hline To see the landscape & 3 & 6 & 9 & \\
\hline part of a tour & 0 & 7 & 7 & \\
\hline see a place of importance to Iceland & 0 & 4 & 4 & \\
\hline Recommended & 1 & 5 & 6 & \\
\hline Convenience & 2 & 3 & 5 & \\
\hline Golden circle & 5 & 6 & 11 & \\
\hline Guidebook & 0 & 4 & 4 & \\
\hline \multicolumn{5}{|l|}{$\begin{array}{l}\text { Did your experience meet your } \\
\text { expectations? If not what changes could } \\
\text { be made to improve future visits? } \\
\end{array}$} \\
\hline Yes & 3 & 25 & \multirow{2}{*}{39} & \multirow{2}{*}{$\begin{array}{l}\text { considerable participants suggested their expectations were met but offered areas for improvement including managing } \\
\text { tourist \#s, warmer, free restrooms, guides, more info, information on sites down paths, and less technical signs }\end{array}$} \\
\hline Yes with explanation & 6 & 5 & & \\
\hline No & 0 & 0 & \multirow{2}{*}{$\mathbf{0}$} & \multirow{2}{*}{$\begin{array}{l}\text { No participants outewardly stated that their experience was not met however, a number of participants did not clarify } \\
\text { one way or the other. }\end{array}$} \\
\hline No with explanation & 0 & 0 & & \\
\hline expectation not stated. Feedback provided & 6 & 5 & 11 & Suggestions for improvement included staggered bus arrivals, free toilets, a larger visitor center with more interprative \\
\hline
\end{tabular}


Likert responses at Sólheimajökull varied slightly from those at Pingvellir (Figure 5.17). In terms of education, the majority of visitors suggested that they learned about the geology of Iceland. When asked if they had learned about the culture of Iceland while at Sólheimajökull, the majority of respondents took a neutral stance. Interpretive signs at Sólheimajökull are largely focused on the environmental processes that lead to the creation and retreat of glaciers. The fact that participants suggest they have learned about the geology of Iceland indicates that interpretive material is being read, or that participants are able to make connections between the site and prior knowledge. When asked about the presentation of information, the majority of visitors suggest that signs are easily understood. Interestingly, despite the large occurrence of trail deviations observed in the eye-tracking trials and GPS data, the majority of visitors suggest that the presence of signs influenced their behavior at Sólheimajökull. Even more interesting, visitors seem to agree that trails, signs, and restricted areas are appropriate tools to decrease environmental degradation and did not diminish visitor experience; yet, considering the large amount of deviation that occurred at Sólheimajökull, these findings suggest that deviation may be caused by a lack of development rather than disregard for posted signage. Still, both factors likely played a part in the documented deviations at Sólheimajökull.

Common motivations for visiting Pingvellir were documented on the assessment instrument. The majority of respondents identified that they visited pingvellir because it was part of a popular Golden Circle tour, which takes tourists to important geologic and cultural locations near to Reykjavík; many survey respondents also noted Pingvellir's proximity to Reykjavík and its inclusion in guidebooks or other tours. Of all the visitors 
to the Pingvellir area who completed a post-assessment, 39 suggested that their expectations had been met. While no respondents indicated that the area failed to meet their expectations, some respondents provided recommendations for improvement. Common suggestions for improvement included decreasing tourist numbers to the site, free restrooms, use of onsite tour guides, and less technical signs.

At Pingvellir, $64 \%$ of visitors reported that they had read signs fully, $30 \%$ suggested they read portions of the signs, and $6 \%$ of visitors reported that they had not read any of the signs at the site. Of the participants who chose to read signs, common reasons for taking time to read the signs included to learn, to know where to go, to know what makes Pingvellir a tourist hotspot, and to know how not to make a mistake. Participants who chose to only read portions of signs indicated that they did so when they could not easily find information in their native language. Additional reasons for having only partially read signs included that they desired more time for walking, information was not what they were looking for, and they already had prior knowledge about the site. Time constraints and being part of a tour group were mentioned as prohibiting factors for the visitors who did not read any signs. While the survey suggests that $64 \%$ of visitors read signs fully, review of eye-tracking data disagrees with this finding. While a large percentage of participants did approach many of the interpretive signs most simply skimmed through the material.

Despite the large number of participants who approached interpretive signs at pingvellir, a number of individuals express confusion regarding the site's significance. For example, Participant 10 stated, "Could you explain to me, this is going to sound really bad, what are we supposed to be seeing here?" (Participant 10, personal 
communication, 2017). Participant 6 makes a similar remark, stating "Okay, what do I do here? I have no idea what I'm doing here." (Participant 6, personal communication, 2017). These are just a couple of examples in what emerged as a common theme of confusion that arose amongst visitors to Pingvellir. The confusion that arose regarding pingvellir's significance was likely the result of overly complex signs, which did not properly inform visitors of the geologic and historical significance of the area. The pingvellir area is one of the only areas of the world where tectonic rift is visible on the surface, yet many visitors expressed frustration in their inability to recognize the rift features while in the Pingvellir area. To bridge the gap between visitor confusion and site significance, data suggests a need for more effective and less complex interpretive signage in the Pingvellir area. When tourists see and understand cultural connections between themselves and the site, the visit can be much more informative, interesting, and enjoyable. During their visit to Pingvellir, Participant 5 stated, "This is so cool, I don't think I have been more satisfied with a historical fact than this moment right here, like learning about it earlier in the week, and then coming here and seeing it, I am just so excited about this historical fact." (Participant 5, personal communication, 2017). This statement reveals that signs are too complex for those who did not have prior knowledge of the site; Participant 5 indicated that they learned about the sites significance earlier in the week making their visit to Pingvellir more enjoyable. Additionally, these data reveal that when site significance is understood, visitor experience is enhanced.

Figure 5.18 shows the attention of one participant while viewing an educational sign at Pingvellir. In this particular example, the participant is observed focusing on the timeline posted along the bottom edge of the sign. Additionally, the participant pays a 
fair amount of attention to the images located throughout the sign; however, this participant avoids the large blocks of text present throughout the sign. Furthermore, later on in this particular segment of visitor attention the participant becomes increasingly distracted by their surrounding environment and attention begins to deviate away from the sign towards the surrounding environment. This example reveals what likely led to the common theme of confusion amongst visitors to Pingvellir. While signs effectively elicit visitor attention they fail to effectively communicate information to visitors. Using mobile eye tracking this study was able to identify certain design flaws amongst signs at pingvellir. Based on these results, future signs should be less complex with a mixture of short text blocks along side visually appealing imagery. 


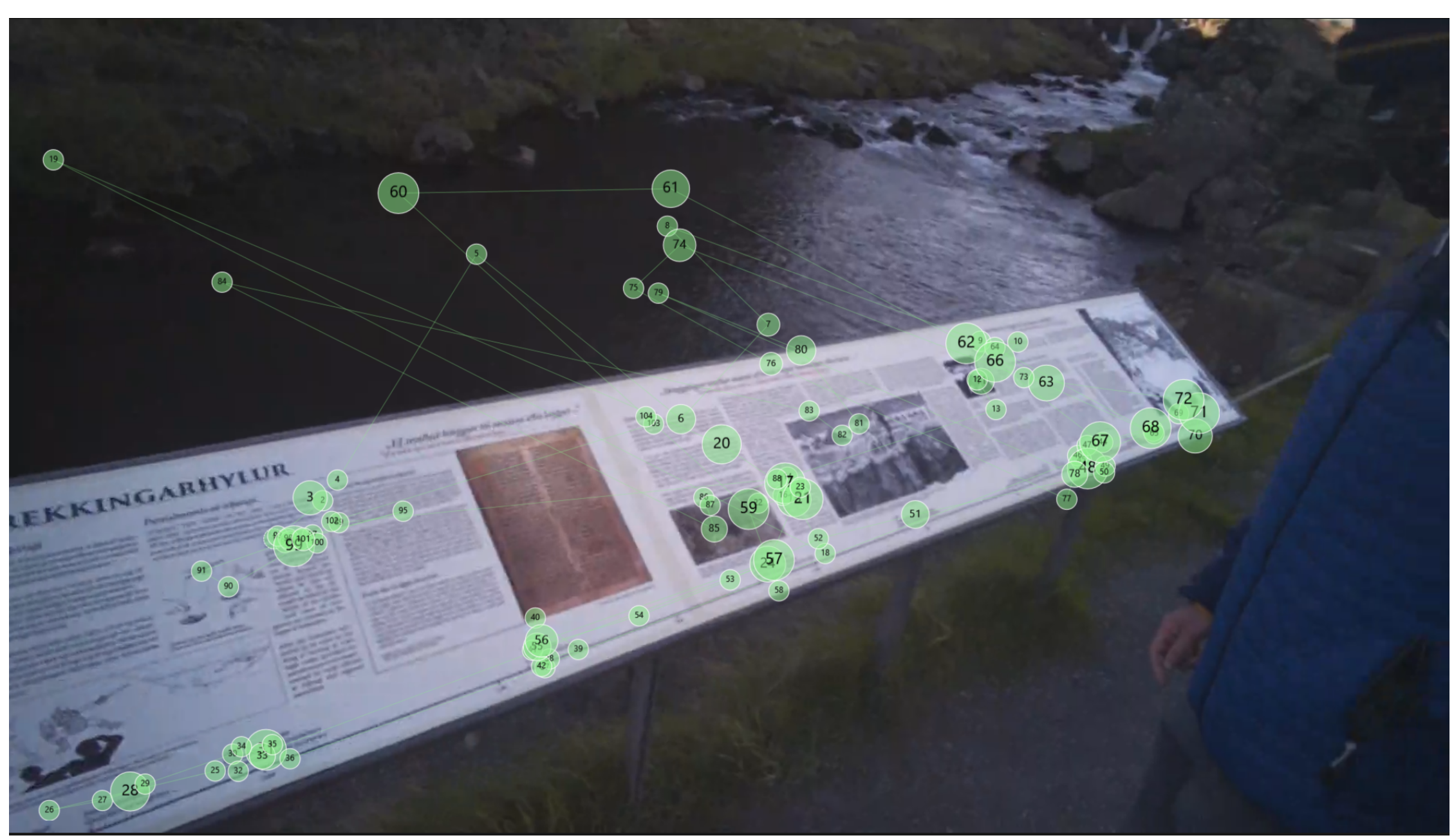

Figure 5.18: Visitor attention while observing a sign at Pingvellir. Lines indicate movement of eyes between fixation points. Order is indicated by the number shown in the circles. The size of the circle (fixation point) indicates time spent fixated on the point. 
Additional confusion regarding site significance can be attributed to the design of directional signs, which aim to guide visitors to various points of interest within the study area. Figure 5.19 shows one example of such signs which were present throughout the study site. As shown in Figure 5.19 signs consist of text written in Icelandic indicating the various points of interest and the direction in which a visitor should travel in order to see these various locations. Additionally, some of the signs included maps to assist visitors' navigation through the study site. In the case of the participant in Figure 5.19, a flaw in the design of these signs was documented; this particular participant avoids the text written on the sign and attempts to understand their location within the study site and instead interprets the map. This is likely due to the fact that points of interest are only provided in Icelandic and, while they communicate effectively to a local audience, they are ineffective at communicating to an international audience. 


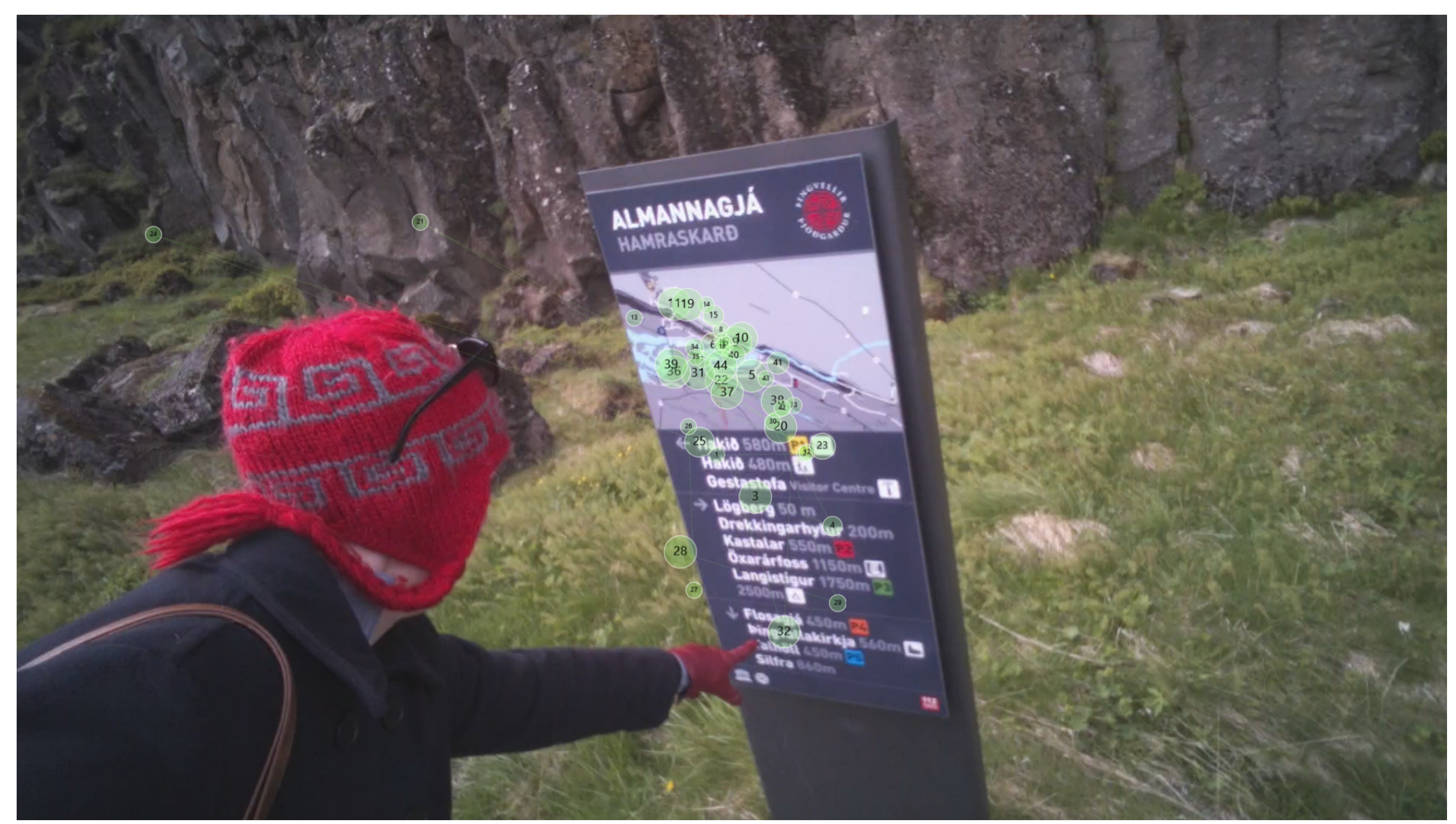

Figure 5.19: Participant attempts to navigate Pingvellir using directional sign. Lines indicate movement of eyes between fixation points. Order is indicated by the number shown in the circles. The size of the circle (fixation point) indicates the amount of time eyes spent fixated on the point. 
Of the 50 post-assessments that were completed at Sólheimajökull, eight common motivations for visiting the area arose. The majority of visitors indicated that they stopped at Sólheimajökull in order to see a glacier. Heading east from Reykjavík, Sólheimajökull is one of the first stops where visitors to Iceland can see a glacier. Many visitors indicated that they stopped at Sólheimajökull because it was convenient, suggesting they were just passing by when they decided to make the stop; other motivations included that it was part of a tour or was suggested in a guidebook. Beauty and nature were also cited as reasons for stopping at Sólheimajökull, as well as a desire to see a glacier before they melt. Visitors stated overwhelmingly that Sólheimajökull had met their expectations, with only $12 \%$ of visitors stating that the site did not meet their expectations. Common reasons among those who were not satisfied with their visit included the large number of tourists in the area, the lack of restrooms, and that they would have liked to go closer to the glacier. Those who did enjoy their visit to Sólheimajökull cited the cleanliness of the area, user-friendly trail, and beauty of the glacier as factors that made their experience enjoyable.

At Sólheimajökull, 33 visitors reported that they had read signs fully, 13 suggested they had read portions of signs, and four visitors reported that they had not read any signs at the study site. Of the participants who indicated that they had read signs, common reasons included safety concerns, interest, and knowledge to prevent damaging the environment; participants also indicated that the signs were short and not a burden to read. Those who only read signs in part stated that they did so because their group had moved on, language was not in native tongue, signs were too long, or they already possessed previous knowledge of glaciers. One visitor who did not read the 
signs, stated that they did not go far enough into the study site to see posted signs; however, signs at Sólheimajökull were present at the trail head so in this instance the signs were simply overlooked.

While the surveys generated mixed responses regarding signs, review of eyetracking trials indicated that only one of 15 eye-tracking participants had actually read informational signs. As shown in Figure 5.18, signs at Sólheimajökull were composed of a mixture of text and photographs. Additionally, information in the signs was presented in Icelandic and English. While the sign does effectively use both images and text to demonstrate the retreat of the glacier, it is still text heavy which may contribute to the large number of participants who elected to overlook the signs.

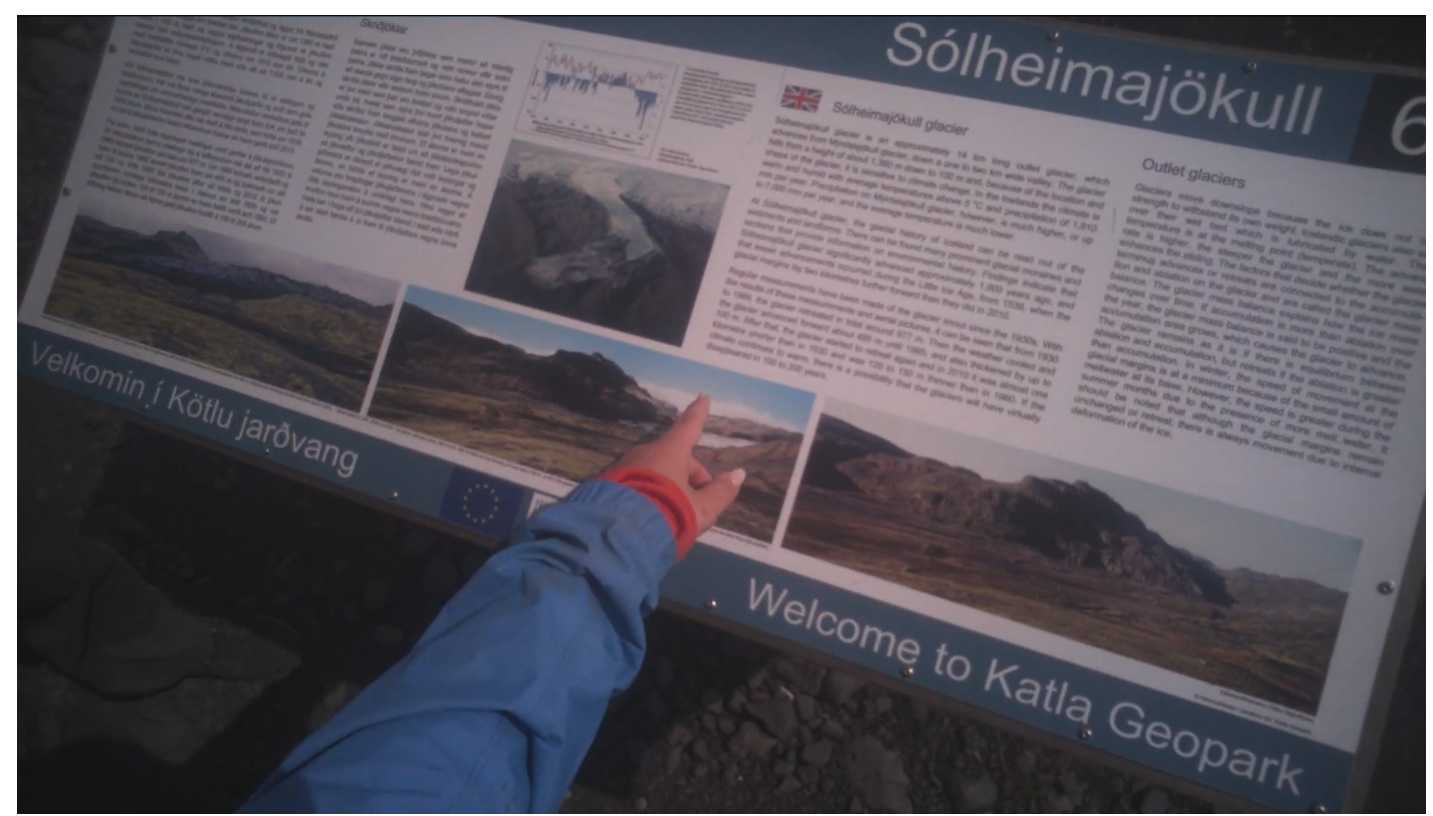

Figure 5.20: Participant 24 reads interpretive sign at Sólheimajökull (created by author).

While the design of signs at Sólheimajökull did not effectively promote visitor engagement, the location of interpretive signs in the area also seems to have discouraged participants from reading them as well. In the case of the 14 eye-tracking participants 
who did not approach the interpretive signs, eagerness to get down the trail towards the glacier seems to be the main influencing factor. While the sign is strategically placed to show that the glacier used to be visible from that location this is no longer the case. For this reason, the interpretive signs may be more effective if placed at the end of the trail where Sólheimajökull is completely within view.

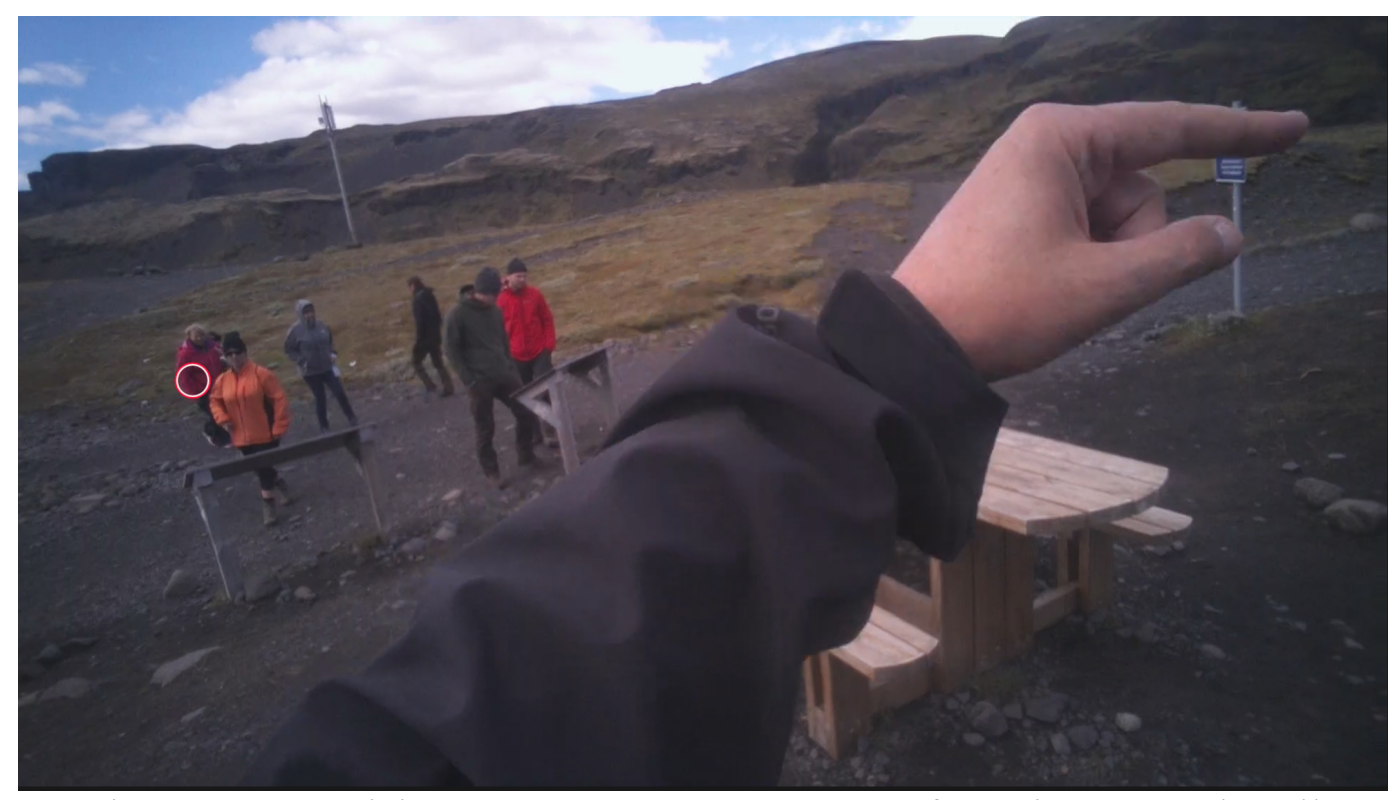

Figure 5.21: Participant 17 gestures a group away from signs towards trail (photo by author).

\subsubsection{Visitor Behavior}

For this study, observed visitor behavior was monitored using the eye-tracking device and observational data collection. The majority of participants at both study sites seem to overwhelmingly agree that trails, signs, and restricted areas are effective strategies for preventing environmental degradation. Furthermore, post-visitation assessment data suggest that visitors to each study site agree that the presence of trails, signs, and restricted areas influenced their behavior. These themes of education and conservation align with common themes of ecotourism outlined by Fennel (2003). 
Additionally, the fact that posted signs, trails, and restricted areas did not negatively impact visitor experience suggests that the majority of visitors to Iceland have mindsets which align with best practices of ecotourism (Fennel 2003). For example, Participant 1 suggests, "The more people that are coming, the more they need to understand how to protect what is here. .. you don't want to spoil things" (Participant 1, personal communication, 2017); this statement typifies the thoughts of an individual whose mindset aligns with ecotourism principles of conservation and the establishment of protected areas (Fennel 2003).

A limitation of this study was the interference of sunny conditions on the ability for the eye-tracking glasses to collect gaze samples; specifically, increased solar radiation led to less gaze samples collected by the eye-tracking glasses. At Sólheimajökull, the average eye-tracking gaze samples only accounted for $38.6 \%$ of participant time spent in the study site, with a maximum sample of $88 \%$ and a minimum of $10 \%$. At Pingvellir, a similar issue arose with the average eye-tracking gaze samples only accounting for $34.3 \%$ of participant time spent in the study site; a maximum sample of $65 \%$ and a minimum of $12 \%$ was recorded at pingvellir. The quality of eye-tracking data collected was largely dependent on the time of day and the amount of cloud cover, both of which reduced UV interference with the glasses' infrared cameras. At earlier and later portions of the day, when the sun was not directly overhead the eye-tracking glasses tended to collect better gaze samples; additionally, more cloud cover equated to better gaze samples collected. Due to the poor collection of eye-tracking gaze samples, voice and video recordings from the eye-tracking glasses were analyzed to identify trends in visitor experience which the visual eye-tracking data may not have fully 
documented. Furthermore, even with less than $100 \%$ eye-tracking data points collected, the eye-tracking data and front-view video recording data that were collected help to both validate and counter responses provided on the assessment instrument.

At Sólheimajökull, data from the eye-tracking trials indicated that the majority of participants paid attention to or acknowledged management signs aimed at deterring unwanted behavior. The high rate of acknowledgement of management-based signs, however, did not translate to effective management of tourist behavior at Sólheimajökull. Based on eye-tracking results, there were three instances when participants acknowledged and adhered to posted signage compared to 16 instances where participants acknowledged and deliberately disobeyed posted signage. This finding suggests additional factors were influencing visitor behavior; these factors included unclear signage, indistinguishable trails, and herd mentality.

Eye-tracking trial data from Pingvellir indicated a drastically different visitor response to interpretive material and management signs at the study site than at Sólheimajökull. Of the 15 Pingvellir eye-tracking participants, only one was observed making a major deviation from the trail. Four minor deviations were observed by four separate participants; however, these deviations were brief and quickly corrected. This trend is likely due to the large distribution of management-based signs (refer to Figure 5.1) present throughout the study site as well as the use of physical barriers such as ropes. Unlike at Sólheimajökull, participants and other visitors were observed at Pingvellir reading informational signs. In the majority of cases where participants were observed reading interpretive signs, the participant appears to read the whole sign; however, some instances do arise where participants only partially read signs. While 
management focused signs were effective at Pingvellir in deterring unwanted visitor behavior the educational signs were often cited as being too complex. The complexity of these signs resulted in a level of confusion amongst visitors to Pingvellir.

Eye-tracking data supported the common frustration of congestion that was mentioned in post-visitation assessments. As mentioned in a report by the Icelandic Tourism Board, the unspoiled impression of Iceland is the main driver influencing tourist's decision to visit the island nation (Óladóttir 2016). This study suggests that Pingvellir exists in stark contrast to the image of unspoiled nature that many tourists expect. Participant 9 refers to the Pingvellir area as "really touristy" (Participant 9 , personal communication, 2017). Throughout the day, busloads of visitors arrive and depart from pingvellir resulting in an overly congested destination which becomes frustrating for many tourists trying to appreciate the landscape (Figure 5.20) (personal observation, 2017). Participant 13 stated, "How is this a national park when there are just manmade paths everywhere? Not manmade as in trails, I am just used to trails like the one down there." In this example, the participant was displeased with the presence of paved trails, stating that she prefers dirt paths such as those that are in many areas of Pingvellir but that have been roped off to the public (Figure 5.21). This supports the findings of Óladóttir (2016) that the unspoiled impression of the landscape is important to uphold when developing tourism destinations in Iceland. Additionally, this finding agrees with a study by Nilsson (2012) that suggests that the majority of tourists to Iceland hold expectations most closely associated with Plog's (1974) allocentric classification. The allocentric tourist is one who is motivated by the desire to have new and authentic experiences. These tourists are then less likely to expect provision of 
Western amenities and development; thus, if development is a limiting factor in a visitor's ability to enjoy these nature-based tourism destinations then methods of influencing visitors' thoughts of their own behaviors effect on the environment must be established. This can be done through the continued promotion of education. In the case of rural tourism development, this is most commonly done through the design and implementation of interpretive signs; yet, the development of effective signs in both placement and content needs to be a priority in future development. This study demonstrates the potential of mobile eye-tracking as a useful tool in the tourism industry. Specifically, after reviewing individual eye-tracking trials and identifying common themes that arose between them, common factors that caused visitors to either engage with or disregard interpretive signs were recognized. Using these findings, interpretive signage at these sites can be more effectively developed in the future. 


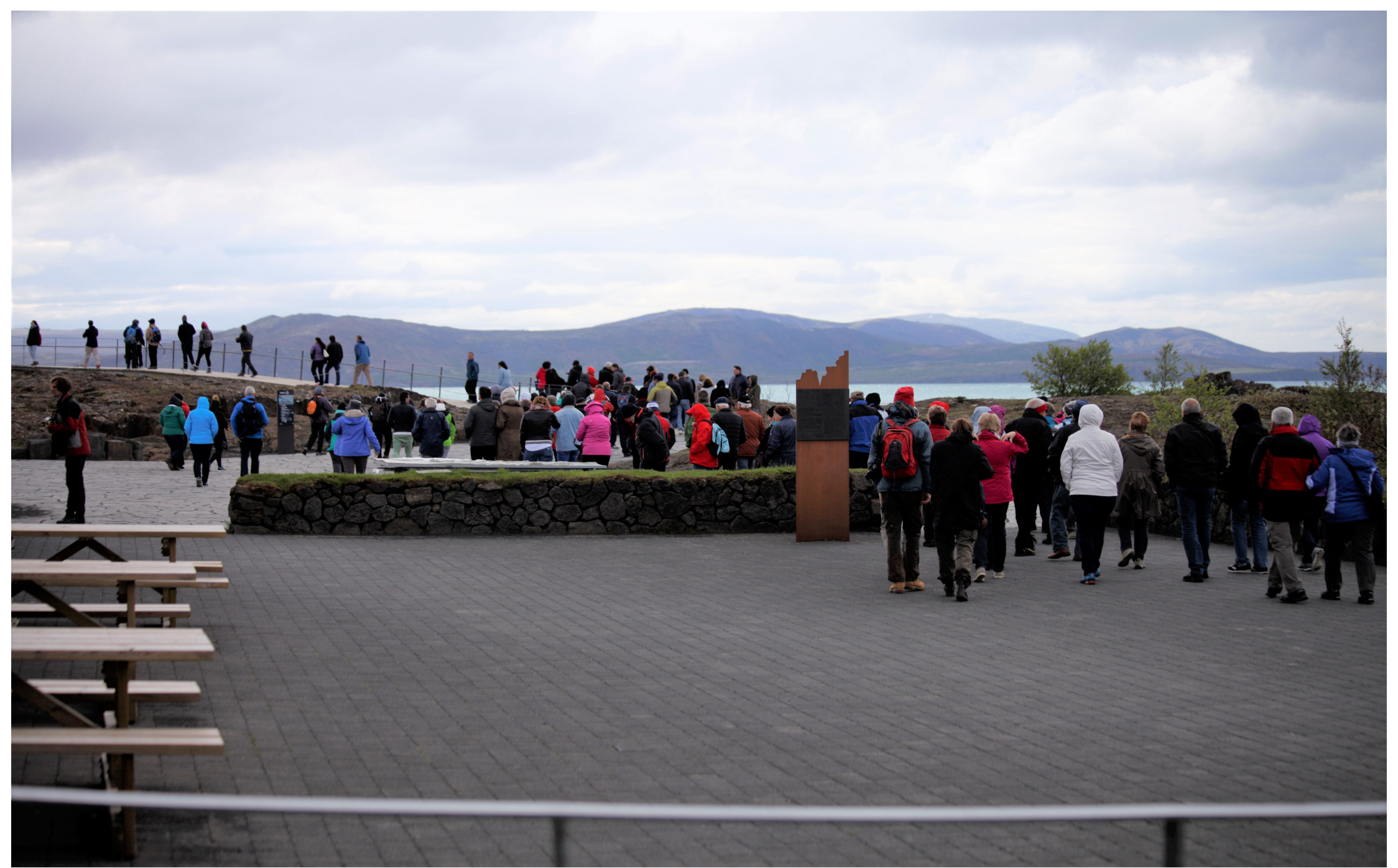

Figure 5.22: Tour group arriving at Pingvellir (photo by author). 


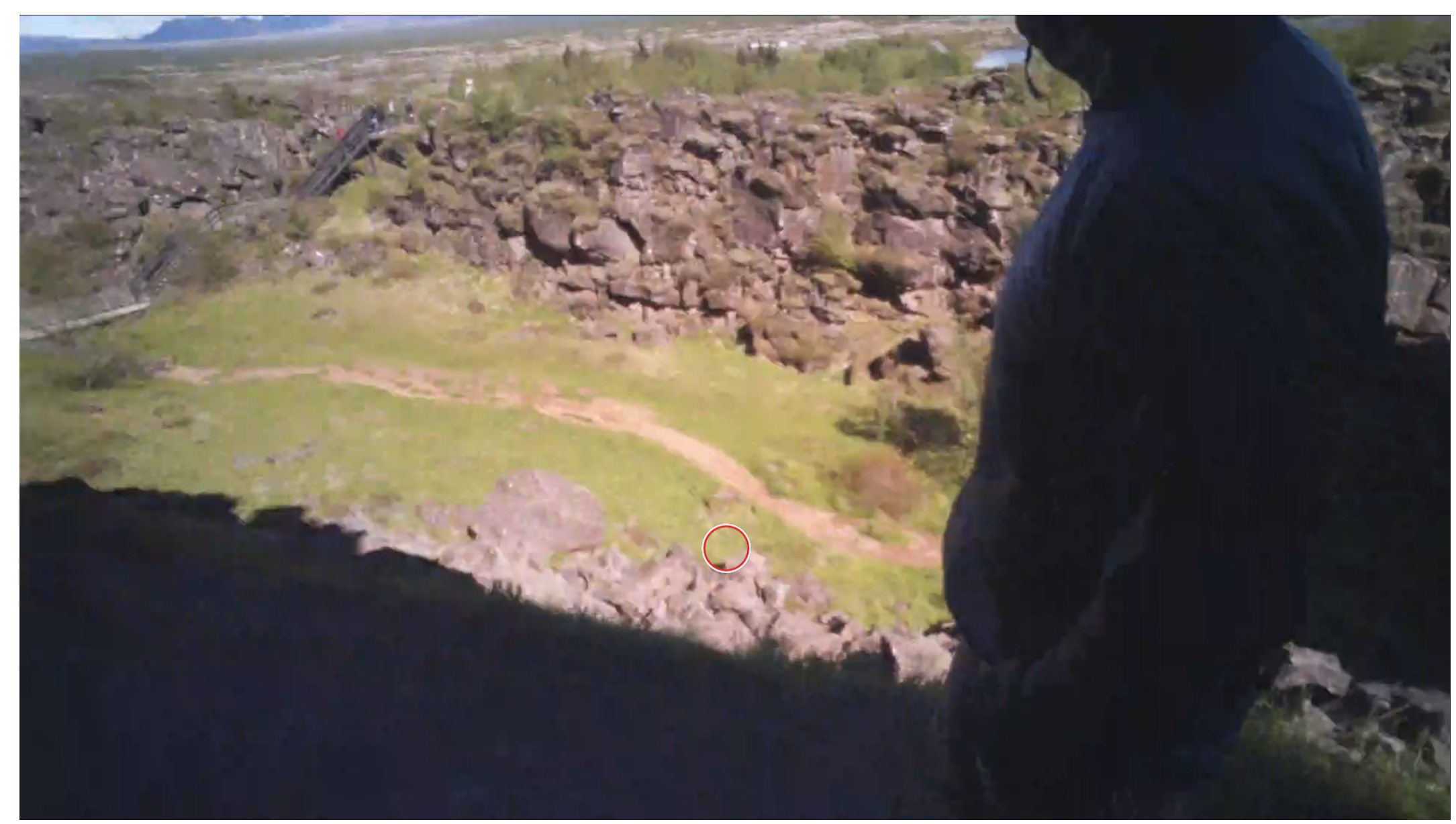

Figure 5.23: Participant 13 points to trail expectation at Pingvellir (photo by author). 
Despite what emerged as a common theme of being underwhelmed with the Pingvellir area, the site effectively manages tourist behavior when compared to Sólheimajökull. Management signs are distributed in great number throughout the Park and the signs are easily interpreted because they use images rather than text to communicate messages to visitors (Figure 5.22). Based on observations of participant and visitor behavior, the concentration of signs, coupled with their easy interpretation, has resulted in effective management of tourist behavior in the Pingvellir area.
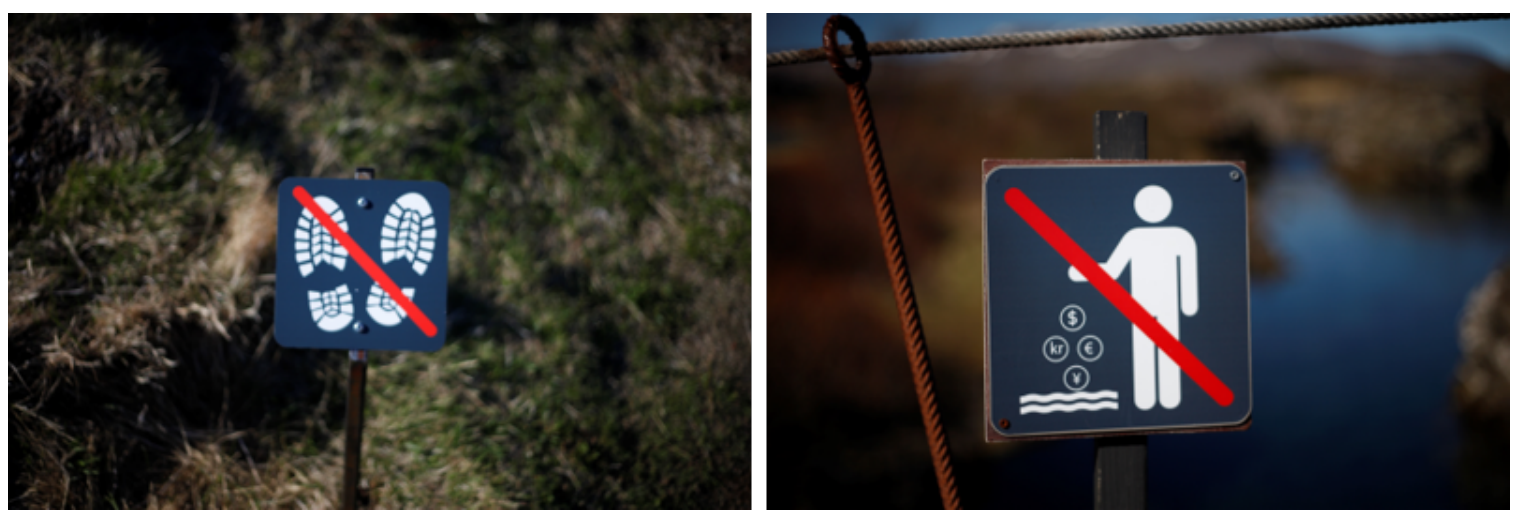

Figure 5.24: Management signs at pingvellir (photos by author).

Visitor behavior at Sólheimajökull varied drastically when compared to visitor behavior at Pingvellir. At Sólheimajökull, data suggest that the ineffective management of visitor behavior is the result of ineffective signage, poor trail development, lack of monitoring, and herd mentality. Posted signage at Sólheimajökull did not resemble those at Pingvellir. Interpretation of signs at Sólheimajökull required fluency in English or Icelandic (see Figure 5.23 and Figure 5.24), making signs ineffective to visitors who might not speak either of the two languages. Results from this study suggest that participants are more likely to disregard management rules if they require understanding and interpretation of text, as opposed to simplified image signs such as those at 
pingvellir. An additional limitation to sign effectiveness at Sólheimajökull is the lack of signs throughout the site. At Pingvellir, signs are posted throughout the Park as a constant reminder reinforcing appropriate behavior; however, at Sólheimajökull, signs are only posted at the trail entrance and trail end, with an additional sign posted at the glacier terminus. With the limited distribution of signs at Sólheimajökull, visitors tend to overlook, disregard, or forget the message of a given sign.

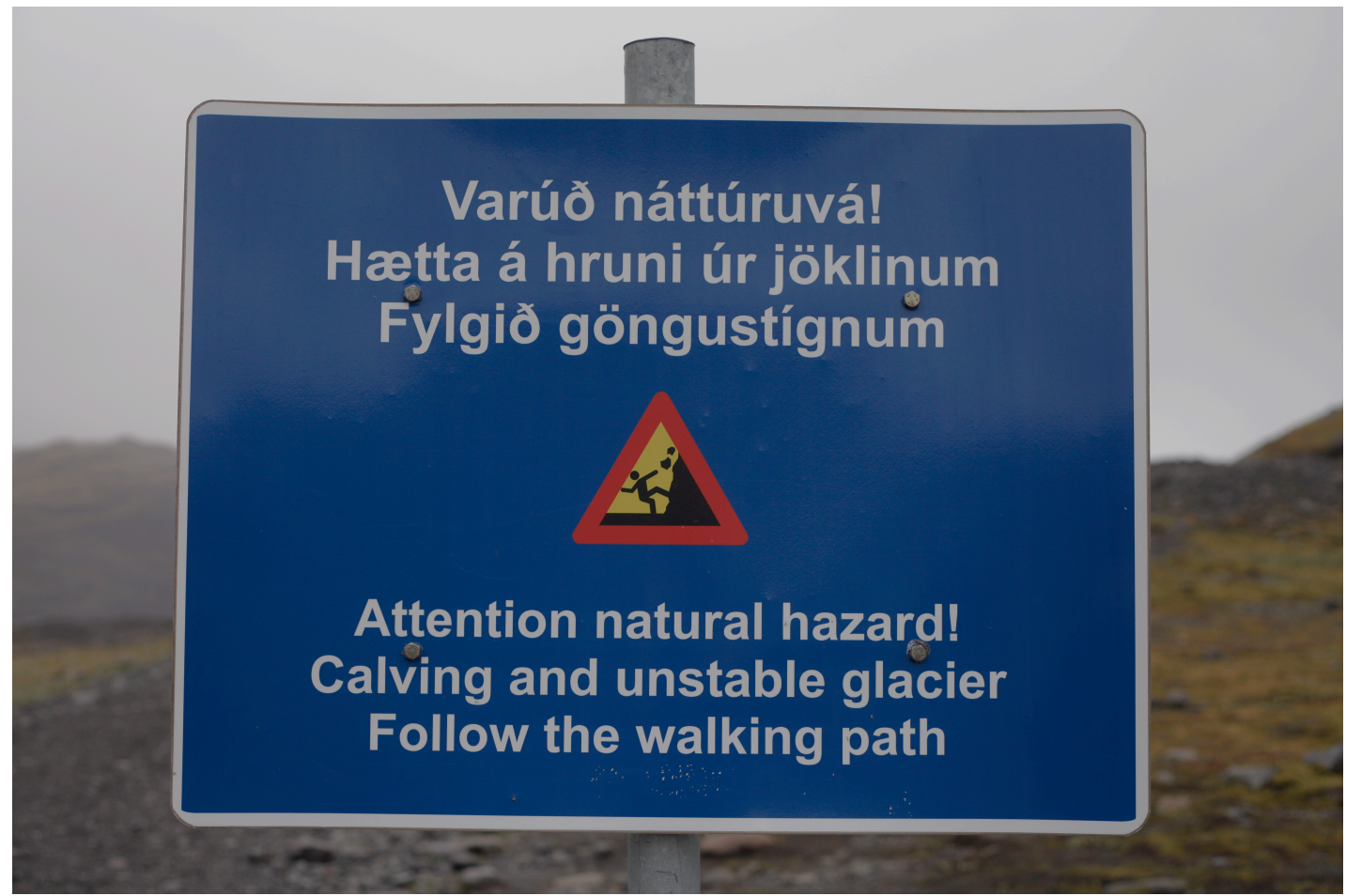

Figure 5.25: Sign at trail entrance and ending at Sólheimajökull (photo by author). 


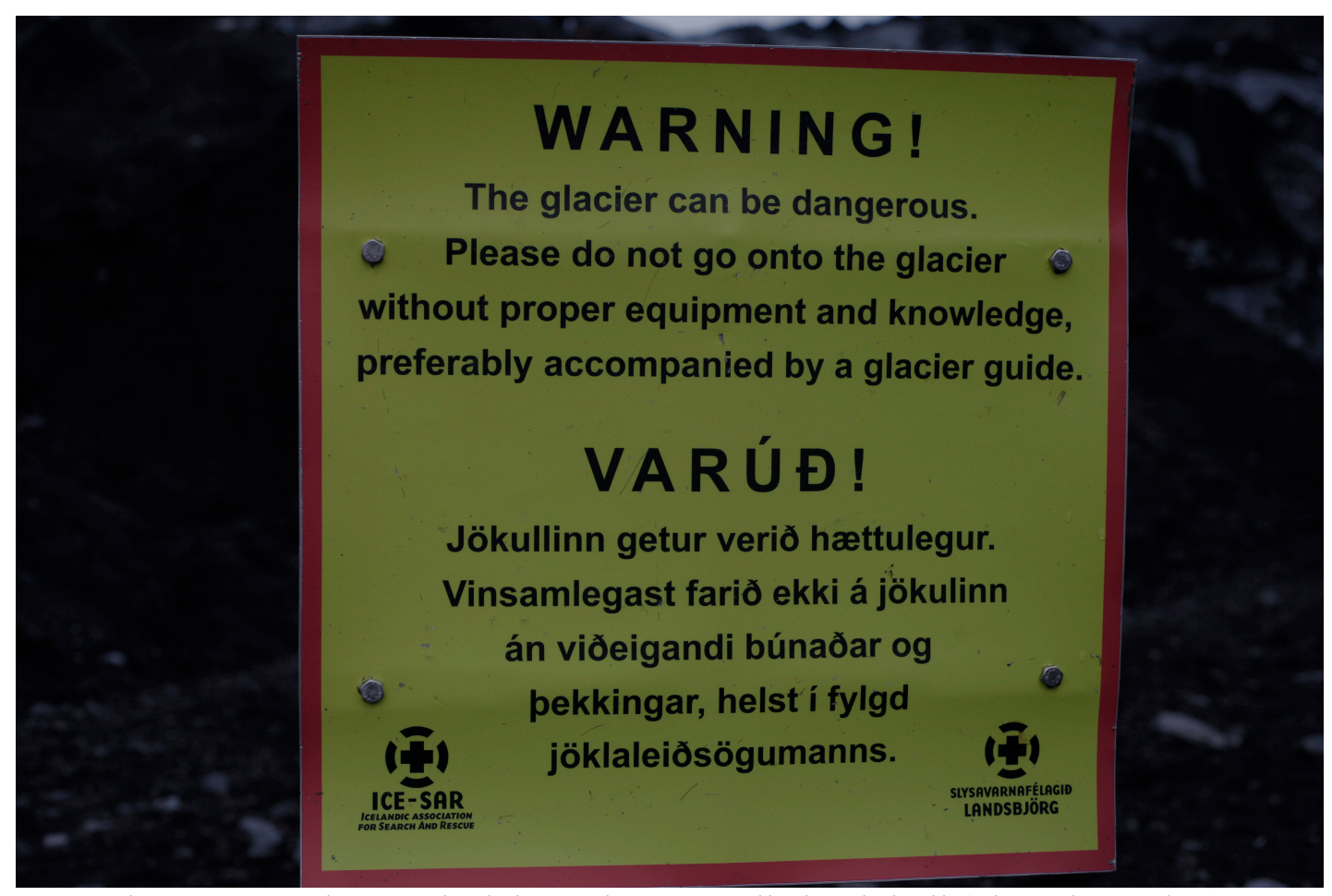

Figure 5.26: Sign at glacial terminus at Sólheimajökull (photo by author).

Herd mentality also contributed to visitor behavior at the study sites. As aforementioned, at Sólheimajökull, 13 of 15 participants were observed deviating from trails. The two participants who were observed adhering to the trail and posted signage were present at the study site earlier in the day when less visitors were present at the study site. What was observed among eye-tracking participants was a tendency for deviation to increase at later parts in the day, when more visitors were present. Figure 5.25 shows one example where Participant 28 is observed interpreting the sign posted at the trails end. In this example, the sign receives the most attention from the participant, followed by a group of visitors who have deviated past this sign. After taking the time to interpret the posted sign, the participant decides to deviate after seeing that other visitors have done so without any repercussions. This was often the case, with many eye- 
tracking participants deviating past the sign when other groups were already past the sign despite observing and reviewing it carefully (Figure 5.25). 


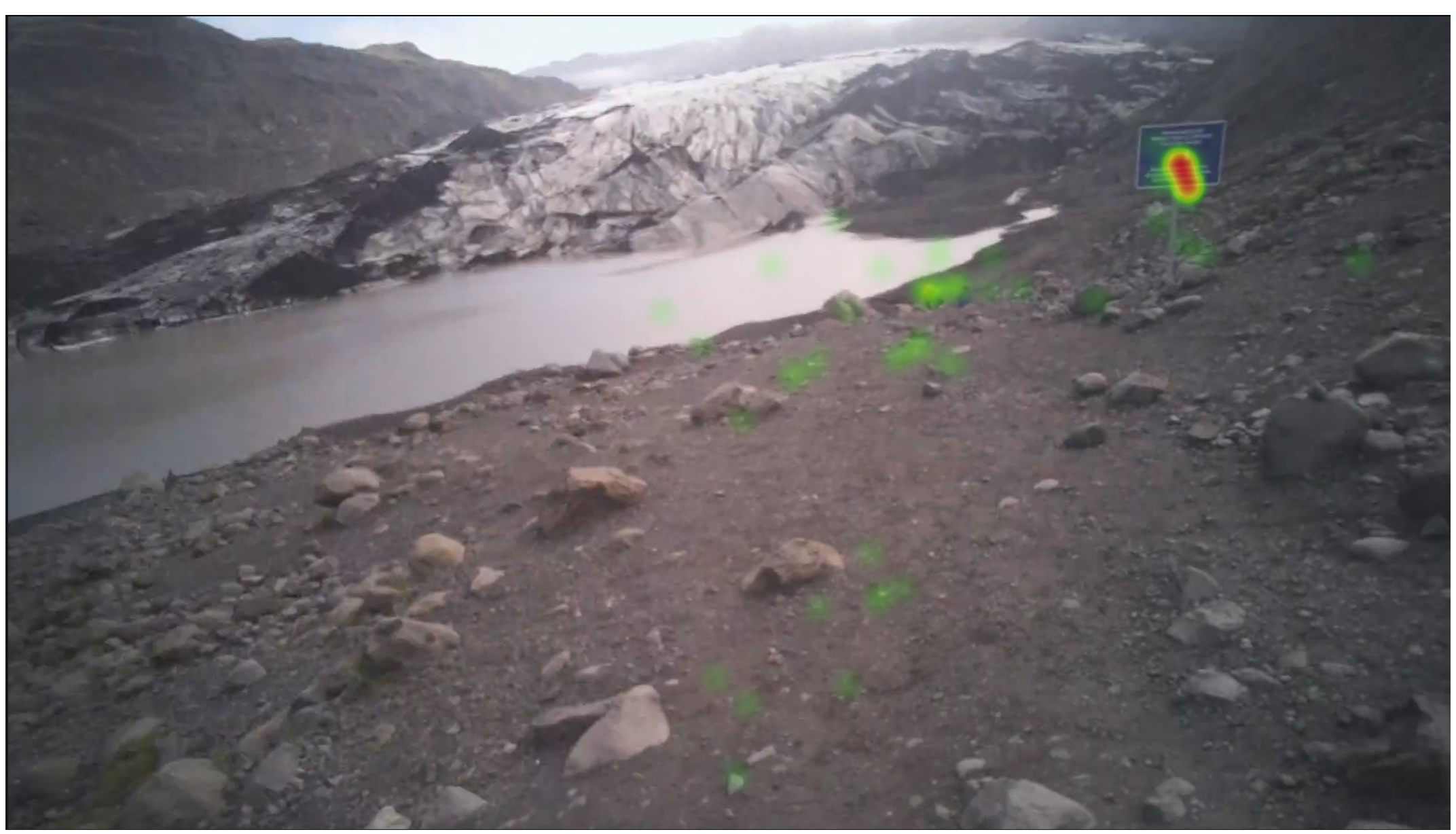

Figure 5.27: Herd mentality documented using eye-tracking heat map (photo by author). 
In summary, development at Sólheimajökull varies drastically from the development that has occurred at Pingvellir. Development at Pingvellir has been effective at managing visitor behavior and is likely the result of easily interpreted management signs. Of those polled, $94 \%$ suggested that they had read signs at least partially. This finding agreed with observations made in eye-tracking trials, where participants were often documented observing both management and educational signs. however, the site fails to provide the experience of unspoiled Icelandic nature and fails to enhance visitor experience through effective interpretation. Zero participants suggest that the site had not met expectations on the post-visitation assessment, yet 11 participants provided recommendations to improve future experience. Further, the assessment data disagreed with observations made in the eye-tracking trials where a vast majority of participants were documented expressing feelings of being underwhelmed and confused by the study site.

In contrast, Sólheimajökull meets visitor expectation in terms of experiencing unspoiled Icelandic nature. This finding is supported by the results of surveys where $86 \%$ of visitors indicated that the site had met expectations. Additionally, little negative feedback was documented during eye-tracking trials. The site, however, fails to manage the behavior of tourists and sign placement fails to elicit visitor attention. While $92 \%$ of survey respondents indicated that they had read signs within the study site, only one in 15 eye-tracking participants was documented reading educational signs. The majority of eye-tracking participants did, however, read management signs at Sólheimajökull. Despite the fact that 14 of 15 eye-tracking participants were observed reading 
management signs at Sólheimajökull, 13 eye-tracking participants were documented deviating from the trail. 


\section{Chapter 6: Conclusions}

The purpose of this study was to assess the application of eye-tracking data in informing the development of ecotourism destinations. This study employed a mixedmethod approach including mobile eye-tracking, GPS footpath analysis, and postvisitation assessments to assess visitor experience and behavior within two popular yet distinctly different tourism sites in Iceland. While the proposed methodology was limited due to the UV interference with gaze sample collection, eye-tracking was still determined to be a useful tool in assessing the development of tourist destinations through the implementation of trails and interpretive signage. Gaze samples allowed quantitative representations of human behavior in the form of heat maps. Through production of these figures, trends such as herd mentality and patterns in visitor attention were documented. In addition, qualitative analysis of eye-tracking data was also performed, including the identification of trends amongst participant dialogue while exploring the study sites. These trends were used to make recommendations for future site development (see section 6.1).

The methodology utilized by this study was designed to answer the following research question:

- In what ways can mobile eye-tracking technology be used to guide the development of mass tourism destinations towards the principles of ecotourism?

- In what ways can mobile eye-tracking technology be used to better understand and influence visitor experience in nature-based tourism destinations? 
- In what ways can interpretive signage prevent environmentally-degrading behavior in nature-based tourism destinations?

- In what ways can tracking a visitor's movement through natural areas add meaning to mobile eye-tracking data?

The response to the primary research question is most effectively answered through addressing the findings of the four sub-questions. Through the collection of visitor footpath data, areas of interest within each study site were identified. Looking at hotspots for both visitation and deviation, areas of interest during eye-tracking trials were identified. Focusing on these particular areas during mobile eye-tracking trials allowed for the identification of influential factors which inspired various behavior amongst participants. One strength of mobile eye-tracking as a tool for assessing development within nature-based tourism destinations is that it provides an honest account of visitor behavior. As was documented when comparing eye-tracking results with results from the post-visitation assessments, respondents often provided idealistic responses to assessment questions rather than answers which reflected actual behavior and experience. That said, mobile eye-tracking was determined to be a useful tool in assessing the development of nature-based tourism areas.

The two study sites, Sólheimajökull and Pingvellir, represent two areas with distinctly different levels of development. Pingvellir boasts an impressive distribution of informational and management focused signs as well as a complex network of welldeveloped trails. Sólheimajökull, in comparison, has limited posted signage. A single series of three informational signs is present at the entrance to the Park. Three additional 
management signs are present in the area at the trail head, trail end, and at the base of the glacier. As opposed to Pingvellir, trail development at Sólheimajökull is minimal, comprised mainly of a rocky and unstable trail that traverses the glacier lateral moraine. The methodology for this study revealed how these differences in this site development led to variations in visitor behavior and experience.

Using GPS, trends in visitor behavior were documented. Obvious differences between the two study sites were identified using a spatial selection and buffer method. At Pingvellir, visitors adhered to developed trail and posted signage and did not deviate from the developed trail with the exception of four minor deviations and one major deviation. At Sólheimajökull, however, 13 of 15 participants were observed making major deviations from the trail. Using the GPS data as a guide, hotspots for visitor foot traffic, as well as hot spots of deviation, were also identified. These hot spots became areas of interest when analyzing eye-tracking data. For example, at Sólheimajökull the location of the second management sign became a point of interest in the analysis of eye-tracking trials. This location served as one of the most common stopping points among visitors to the study site, suggesting that visitors are stopping to interpret the sign present at the location. This was confirmed through the review of eye-tracking trials, yet, despite the fact that 14 of 15 participants stopped to interpret the management sign, 12 deviations were documented in this location. Based on review of eye-tracking trials, complexity of signs and herd mentality were determined to be the main influence on visitor's decision to deviate within this study site. 
Post-visitation assessments were administered to the 30 eye-tracking participants and an additional 70 respondents. These assessments were important in identifying trends in visitor expectations and mindsets. Results from the assessments indicate that the majority of visitors' mindsets align with common principles of ecotourism including education and conservation (Fennel 2003). Despite this mindset held by the majority of visitors, inconsistencies were observed in visitor behavior, particularly at Sólheimajökull. This disagreement between surveys and behavior, namely the large occurrence of deviation at Sólheimajökull, highlights one of the strengths of mobile eyetracking as a tool for assessing tourism development. While many visitors provided idealistic responses on post-assessments, survey results are not an honest account of how visitors behaved within the study sites. If assumptions were drawn about visitor behavior based on post-visitation assessments alone, they would be invalid. Based on the strong agreement that trails, signs, and/or restricted areas are appropriate tools to decrease damage to the environment, and strong disagreement that the designation of restricted areas negatively impacted experience provided in post-visitation assessment responses at Sólheimajökull, one would expect to observe visitors adhering to posted signage and sticking to the trail; however, after reviewing eye-tracking trials and GPS data, this was not determined to be the case. In this instance, the merit of mobile eye-tracking as a tool to assess visitor behavior in nature-based tourism destinations is highlighted as it provides an honest account of true visitor behavior and experience.

The use of eye-tracking in the tourism industry provides an invaluable and honest account of tourism behavior and experience within tourism destinations. The 
behavior of eye-tracking participants closely resembled that of common visitors and, thus, it was determined that wearing the eye-tracking device did not significantly alter visitor behavior. The original intent of this study was to conduct extensive quantitative analysis on eye-tracking data; however, solar radiation interfered with the integrity of the collected eye-tracking data. While quantitative analysis was used to show the effects of herd mentality on tourist behavior, as well as common trends in visitor attention, the majority of eye-tracking analysis was qualitative in nature. For each participant, dialogue and behavior was transcribed and coded in order to recognize common themes in visitor behavior. The audio and visual data were correlated to an accurate and authentic account of participant behavior. The qualitative analysis of eye-tracking data serves as one method by which future studies can draw additional conclusions from eyetracking ecotourism studies.

While GPS and eye-tracking data can be used on their own to identify trends in participant behavior, using them in conjunction with one another allowed for the identification of participant behavior, as well as likely causes for documented participant behavior. Not only can eye-tracking technology and GPS be used in conjunction to identify shortcomings in current tourism site development, they may also be used to promote future development of a site through identification of underserved areas and ineffective signage.

\subsection{Recommendations for Future Development}

Based on the results of this study, development at Pingvellir is more effective at managing the behavior of visitors. In spite of this, visitors to the Pingvellir area were 
often times left underwhelmed by the area and uncertain of its significance. In several cases where participants were documented enjoying their visit to Pingvellir, it was in large part due to the recognition of the sites' cultural and geologic worth. To improve the experience of future visitors, steps must be taken to improve the distribution of information through interpretive material. While the distribution of signs throughout Dingvellir was effective in eliciting visitor attention, participants commonly suggested a level of complexity in sign design. Future development activities should aim to install new signs to improve visitor understanding and engagement. The use of bulleted lists rather than large blocks of text is one simple adjustment that could be made to increase visitor perception. Additionally, easily distinguished sections of different languages may assist in reaching a larger audience (Rand 1990; Serrell 1996).

Sólheimajökull produced little negative feedback from eye-tracking participants and respondents. The positive experience held by visitors to Sólheimajökull is likely related to the impression of unspoiled Icelandic nature. The limited development which has occurred at Sólheimajökull provides an authentic experience to its visitors, but fails to manage tourist behavior; however, interpretive material was often ignored, likely the result of its placement and complexity. Signs at Sólheimajökull are sparsely distributed throughput the study site. Additionally, signs are more complex than management signs present at Pingvellir which are easily interpreted images, rather than text based signs that require proficiency in English or Icelandic. The challenge for site managers moving forward is identifying levels of development which manage visitor behavior while also providing the natural experience that tourists seek. This can only be done through the 
education of visitors with the implementation of effective interpretive material, especially when considering the largely rural nature of Icelandic tourist destinations.

While visitors to Sólheimajökull were commonly documented having had a positive experience at the study site, little efforts have been made to prevent unwanted visitor behavior. To prevent the large occurrence of deviation at Sólheimajökull, methods of interpretation could be borrowed from Pingvellir; signs such as those in Figure 5.22 could be effective if implemented at Sólheimajökull. These signs would be effective as they are able to communicate across multiple linguistic barriers; additionally, their placement along the ground would be effective as the rocky trail tends to attract visitor attention. In addition to the placement of management signs along the trail, the site may see benefit in placing its educational signs throughout the study site as opposed to their current placement at the entrance. Placing signs near the end of the trail, specifically, would place information at a natural stopping point for visitors increasing the likelihood that visitors will stop to read them.

In conclusion, both study site would likely benefit from the design of more effective interpretive material. Signs at both Sólheimajökull and Pingvellir contained large blocks of small text and included minimal amounts of images. As a result, eyetracking participants were documented only sparsely reading and properly interpreting interpretive signs at the study sites. Simple modifications that could be made include the use of large font types which minimize perceived difficulty of interpretation. The more challenging a visitor perceives a sign to interpret, the less likely he or she is to approach the sign (Rand 1990). Furthermore, text blocks should be limited to segments ranging 
from 25 to 75 words accompanied by visually appealing images and figures (Serrell 1996). Further, a study by Bitgood (2000) suggests that engaging multiple senses may increase attention and, in turn, the perception of information within interpretive material. For example, although beyond the scope of investigation in this study, interactive signs that include flip labels which pose questions on the front and present answers on the back could be installed at both study sites.

\subsection{Future Research}

Future studies may look to develop more interpretive signs for the Sólheimajökull and pingvellir areas. This may be done more effectively through the use of a stationary eye-tracking device. Studies aimed at assessing the effectiveness of interpretive signs would be better served through the use of static eye-tracking devices, as they ensure the participants focus on each individual sign. With the mobile eyetracking device used in this study, video resolution as well as UV interference prevented the analysis of participant attention on interpretive signs. Use of static eye-tracking devices would negate these limitations, allowing clear and uninterrupted visualizations of participant attention.

After having developed new interpretive signs which effectively engage individuals within static environments, their effectiveness when incorporated back into their respective environments should be assessed. This can be done through the use of a similar methodology as the one proposed in this study. By comparing future trends in visitor movement and feedback with those of this study, the effectiveness of new interpretive signage can be assessed. Placement of future signs should be guided by the 
results of this study; signs should be placed along natural stopping points identified through the kernel density analysis of visitor footpath data.

Finally, future studies may look to apply mobile eye-tracking technology in increasingly diverse environments. This study used mobile eye-tracking in outdoor environments within Iceland. UV interference was identified as a problem which must be addressed in the future to validate mobile eye-tracking as a useful tool in the ecotourism sector. Future studies may look to apply eye-tracking technology in low light areas such as caves. In many parts of the world show caves attract visitors in great numbers. Much like ecotourism destinations in Iceland caves serve as an ideal environment to educate visitors through personal and non-personal interpretive practices. Unlike outdoor ecotourism environments show caves are illuminated through the use of artificial lighting. In many cases these environments are lit only enough to see various features as excessive lighting can cause degradation to the cave ecosystems. Use of mobile eye-tracking technology in these environments will serve to identify strengths and weaknesses of the technology in increasingly diverse environments. 


\section{Chapter 7: Literature Cited}

Ajzen, I. and Fishbein, M., 1980. Understanding attitudes and predicting social behaviour. Englewood Cliffs, NJ: Prentice-Hall.

Arndt, M.A., Screven, C., Benusa, D. and Bishop, T., 1993. Behavior and learning in a zoo environment under different signage conditions. Visitor Studies 5(1), 245253.

Ballantyne, R., Packer, J. and Falk, J., 2011. Visitors' learning for environmental sustainability: Testing short-and long-term impacts of wildlife tourism experiences using structural equation modelling. Tourism Management 32(6), 1243-1252.

Basit, T., 2003. Manual or electronic? The role of coding in qualitative data analysis. Educational Research 45(2), 143-154.

Bell, A., 2010. Pingvellir: Archaeology of the Althing. Master's thesis, University of Iceland. Humanities Department. Retrieved from http://skemman.is/stream/get/ 1946/6937/18731/1/\%C3\%9EingvellirAJB.pdf.

Benediktsson, K., Lund, K.A., and Huijbens, E., 2011. Inspired by Eruptions? Eyjafjallajökull and Icelandic Tourism. Mobilities 6(1), 77-84.

Beymer, D., Russell, D., and Orton, P., 2008, September. An Eye-tracking Study of How Font Size and Type Influence Online Reading. The British Computer Society 2, 15-18.

Bitgood, S., 2000. The role of attention in designing effective interpretive labels. Journal of Interpretation Research (5)2, 31-45.

Björnsson, H. and Pálsson, F., 2008. Icelandic Glaciers. Jökull 58, 365-386.

Boyd, S.W. and Butler, R.W., 1996. Managing ecotourism: an opportunity spectrum approach. Tourism Management 17(8), 557-566.

Boyne, S., 2003. New Directions in Rural Tourism Impact Research. In Hall D., Roberts, L., and Mitchell, M. (eds.) New Directions in Rural Tourism, 19-37. Ashgate Publishing Company: Burlington.

Brandenburg, A., 1998. Disc Turbulence and Viscosity. In: Abramowicz, M., Bjornsson, G., and Pringle, J. (eds.) Theory of Black Hole Accretion Discs, 61-68. University Press: Cambridge. 
Brougham, J.E. and Butler, R.W., 1981. A Segmentation Analysis of Resident Attitudes to the Social Impact of Tourism. Annals of Tourism Research 8(4), 569-590.

Centre, U.N.E.S.C.O., (n.d.) Pingvellir National Park. Retrieved 17 November 2016 from http://whc.unesco.org/en/list/1152.

Coffield, F., 2000. The Structure Below the Surface: Reassessing the Significance of Informal Learning. In: Coffield, F. (ed.) The Necessity of Informal Learning, 111. Policy Press: Bristol.

CIA (Central Intelligence Agency), 2016. The World Factbook: Iceland Geography. Retreived November 30, 2016, from: https://www.cia.gov/library/ publications/the-world-factbook/geos/ic.html.

Cohen, E., 1987. Alternative Tourism-A Critique. Tourism Recreation Research 12(2), 13-18.

Duchowski, A., 2007. Eye-tracking Methodology. Springer: London.

Esterberg, K., 2002. Qualitative Methods in Social Research, $1^{\text {st }}$ ed. Columbus: Mcgraw Hill Higher Education.

Evans, K.M., Jacobs, R.A., Tarduno, J.A., and Pelz, J.B., 2012. Collecting and Analyzing Eye-tracking Data in Outdoor Environments. Journal of Eye Movement Research 5(2), 6.

Falk, J.H. and Dierking, L.D., 2000. Learning From Museums: Visitor Experiences and the Making of Meaning. Alta Mira Press: Walnut Creek.

Fennell, D.A., 2003. Ecotourism. Routledge: New York.

Friis, B., 2011. Late Holocene Glacial History of Sólheimajökull, Southern Iceland. Masters thesis, School of Earth Sciences, University of Iceland. Retrieved from: http://skemman.is/stream/get/1946/7407/19823/1/Bjarki_Friis_master_thesis_rea dy_for_printing_V3.pdf.

Gilbert, R., 2003. Ecotourism and education for sustainability: a critical approach. International Review for Environmental Strategies 4(1), 75-83.

Gudmundsson, M.T., Pedersen, R., Vogfjörd, K., Thorbjarnardóttir, B., Jakobsdóttir, S., and Roberts, M.J., 2010. Eruptions of Eyjafjallajökull Volcano, Iceland. Eos, Transactions American Geophysical Union 91(21), 190-191. 
Hall, C., Harrison, D., Weaver, D., and Wall, G., 2015. Vanishing Peripheries: Does Tourism Consume Places. In: Singh, T. (ed) Challenges in Tourism Research. Channel View Publications: Tonawanda.

Hall, C. and Page, S., 2009. The Geography of Tourism and Recreation. Routledge: New York.

Hetzer, W., 1965. Environment, Tourism, Culture. Links 1(3).

Hlöðum, S., 2015. Iceland Road Guide. Vegahandbókin: Poland.

Ingólfsson, Ó., (n.d.)a. The Dynamic Climate of Iceland. Retrieved 12 November 2016 from https://notendur.hi.is/oi/climate_in_iceland.htm.

Ingólfsson, Ó., (n.d.)b. Icelandic Glaciers. Retrieved 13 November 2016 from https://notendur.hi.is// oi/icelandic_glaciers.htm.

Jóhannesson, G., Huijbens, E., and Sharpley, R., 2010. Icelandic Tourism: Past Directions-Future Challenges. Tourism Geographies 12(2), 278-301.

Jóhannesson, G. and Huijbens, E., 2010. Tourism in Times of Crisis: Exploring the Discourse of Tourism Development in Iceland. Current Issues in Tourism 13(5), 419-434.

Johnston, M., Viken, A., and Dawson, J., 2013. Firsts and Lasts in Arctic Tourism. In: Lemelin, H., Dawson, J. and Stewart, E.J. (eds.) Last Chance Tourism: Adapting Tourism Opportunities in a Changing World. Routledge: New York.

Karlsson, G., Matthíasson, B., and Kristinsson, V. 2018. Iceland. Retrieved 21 March 2018 from https://www.britannica.com/place/Iceland.

Kiefer, P., Straub, F., and Raubal, M., 2012. Towards location-aware mobile eye tracking. In Proceedings of the Symposium on Eye-tracking Research and Applications. 313-316.

Krippendorf, J., 1982. Towards New Tourism Policies: The Importance of Environmental and Sociocultural Factors. Tourism Management 3(3), 135-148.

Lau, G. and McKercher, B., 2006. Understanding tourist movement patterns in a destination: A GIS approach. Tourism and Hospitality Research 7(1), 39-49.

Lindberg, K., 1991. Policies for Maximizing Nature Tourism's Ecological and Economic Benefits. World Resources Institute: Washington, DC. 
Littlefair, C. and Buckley, R., 2008. Interpretation Reduces Ecological Impacts of Visitors to World Heritage Sites. AMBIO: A Journal of the Human Environment 37(5), 338-341.

Livingstone, D., 2007. Informal Learning: Conceptual Distinctions and Preliminary Findings. In: Bekerman Z., Burbules, N., and Silberman-Keller, D. (eds.) Learning in Places: The Informal Learning Educations Reader, 203-228. Peter Lang Publishing: New York.

Loftsdóttir, Á., 2016. Energy Statistics in Iceland 2015. Retrieved 13 November 2016 from http://os.is/gogn/os-onnur-rit/orkutolur_2015-enska.pdf.

Marsh, J. and Staple, S., 1995. Cruise Tourism in the Canadian Arctic and its Implications. In: Hall, C. and Johnston, M. (eds.) Polar tourism: tourism in the Arctic and Antarctic regions, 63-72. Wiley \& Sons: Chichester, UK.

Martin, D.C., 1987. Effect of various communicative methods for controlling visitor removal of pumice at Mount St. Helens National Volcanic Monument. Doctoral dissertation, School of Environmental and Forest Sciences. University of Washington.

Mayer, R.E., 2010. Unique Contributions of Eye-Tracking Research to the Study of Learning with Graphics. Learning and instruction 20(2), 167-171.

Midtgard, M., 2003. Authenticity - Tourist Experiences in the Norwegion Periphery. In: Hall D., Roberts, L., and Mitchell, M. (eds.). New Directions in Rural Tourism, 102-114. Ashgate Publishing Company: Burlington.

Miller, H.J., 2004. Tobler's First Law and Spatial Analysis. Annals of the Association of American Geographers 94(2), 284-289.

Munro, J., Morrison-Saunders, A., and Hughes, M., 2008. Environmental Interpretation Evaluation in Natural Areas. Journal of Ecotourism 7(1), 1-14.

Nilsson, Å., 2012. Tourist Background and Local Acceptance: A Case Study of Tourists in Northern Iceland. Icelandic Tourism Research Center 1-44.

North, L.A., 2011. Informal Karst Education in the United States and Internationally. Doctoral Dissertation, Department of Geography and Environmental Science and Policy, University of South Florida. Retrieved from http://scholarcommons.usf.edu/etd/3265/.

Orams, M., 1996. Using Interpretation to Manage Nature-Based Tourism. Journal of Sustainable Tourism 4(2), 81-94. 
Orlowski, J., 2012. Chasing Ice (Film). Distributed by Submarine Deluxe.

Óladóttir, O., 2012. Tourism in Iceland in Figures. Icelandic Tourist Board. Retrieved from http://www.ferdamalastofa.is/static/files/upload/files/Tourism_in_ Iceland_in_figures_May_\%202012.pdf.

Óladóttir, O., 2013. Tourism in Iceland in Figures. Icelandic Tourist Board. Retrieved from http://www.ferdamalastofa.is/static/files/ferdamalastofa/talnaefni/tourismin-iceland-in-figures-april-2013.pdf.

Óladóttir, O., 2014. Tourism in Iceland in Figures. Icelandic Tourist Board. Retrieved from http://www.ferdamalastofa.is/static/files/ferdamalastofa/Frettamyndir/ 2014/mai/toursim_in_icland_infigf2014.pdf.

Óladóttir, O., 2015. Tourism in Iceland in Figures. Icelandic Tourist Board. Retrieved from http://www.ferdamalastofa.is/static/files/ferdamalastofa/Frettamyndir/ 2015/mai/tourism-in-iceland-in-figures_15.pdf.

Óladóttir, O., 2016. Tourism in Iceland in Figures. Icelandic Tourist Board. Retrieved from http://www.ferdamalastofa.is/static/files/ferdamalastofa/Frettamyndir/ 2016/juni/tourism_-in_iceland_in_figures_may2016.pdf.

Óladóttir, O., 2017. Tourism in Iceland in Figures. Icelandic Tourist Board. Retrieved from:https://www.ferdamalastofa.is/static/files/ferdamalastofa/Frettamyndir/201 7/juli/tourism-in-iceland-2017-9.pdf

Olafsdottir, R. and Runnström, M.C., 2009. A GIS Approach to Evaluating Ecological Sensitivity for Tourism Development in Fragile Environments. A case study from SE Iceland. Scandinavian Journal of Hospitality and Tourism 9(1), pp.2238.

Ozcelik, E., Karakus, T., Kursun, E., and Cagiltay, K., 2009. An Eye-Tracking Study of How Color Coding Affects Multimedia Learning. Computers \& Education 53(2), 445-453.

Porsteinsson, P., 2017. Inbound tourism expenditure in Iceland by consumption products and classes of visitors. Statistics Iceland. Retrieved 15 May 2017 from:http://px. hagstofa.is/pxen/pxweb/en/Atvinnuvegir/Atvinnuvegir_ferdathjonusta_ferdaid nadur_ferdaidnadur/SAM08000.px.

Plog, S., 1974. Why Destination Areas Rise and Fall in Popularity. Cornell Hotel and Restaurant Administration Quarterly 14(4), 55-58. 
Powell, R.B., and Ham, S.H., 2008. Can Ecotourism Interpretation Really Lead to ProConservation Knowledge, Attitudes and Behavior? Evidence from the Galapagos Islands. Journal of Sustainable Tourism 16(4), 467-489.

Prosser, R., 1994. Societal Change and Growth in Alternative Tourism. In: Cater, E. and Lowman, G. (eds.) Ecotourism: A Sustainable Option, 19-37. Chichester: John Wiley \& Sons: Chichester.

Rand, J. 1990. Fish stories that hook readers: Interpretive graphics at the Monterey. Technical Report 90-20. Jacksonville, AL: Center for Social Design. Reprinted from presentation at AAZPA 1985 Annual Conference Proceedings.

Russell, A.J., Tweed, F.S., Roberts, M.J., Harris, T.D., Gudmundsson, M.T., Knudsen, Ó., and Marren, P.M., 2010. An Unusual Jökulhlaup Resulting From Subglacial Volcanism, Sólheimajökull, Iceland. Quaternary Science Reviews 29(11), 13631381.

Sæpórsdóttir, A.D., Hall, C.M., and Saarinen, J., 2011. Making wilderness: Tourism and the history of the wilderness idea in Iceland. Polar Geography 34(4), 249- 273.

Serrell, B., 1996. Exhibit labels: An interpretive approach. Walnut Creek, CA: AltiMira Press.

Staines, K.E., Carrivick, J.L., Tweed, F.S., Evans, A.J., Russell, A.J., Jóhannesson, T., and Roberts, M., 2015. A multi- dimensional analysis of pro- glacial landscape change at Sólheimajökull, southern Iceland. Earth Surface Processes and Landforms 40(6), 809-822.

Stewart, E.J., Draper, D., and Johnston, M.E., 2005. A Review of Tourism Research in the Polar Regions. Arctic 58(4), 383-394.

Stoep, G.A.V. and Gramann, J.H., 1987. The effect of verbal appeals and incentives on depreciative behavior among youthful park visitors. Journal of Leisure Research 19(2), 69-83.

Swearingen, T.C. and Johnson, D.R., 1988. An analysis of off-trail hiking in response to selected social control techniques at Paradise Meadows, Mount Rainier National Park. National Park Service, Cooperative Park Studies Unit, College of Forest Resources, University of Washington.

Tanenhaus, M.K., and Spivey-Knowlton, M.J., 1996. Eye-tracking. Language and Cognitive Processes 11(6), 583-588.

Thompson, P., 1995. The Errant E-Word: Putting Ecotourism Back On Track. Explore 73, 67-72. 
Thompson, D. and Bitgood, S., 1988. Chapter 10: The Effects of Sign Length, Letter Size, and Proximity on Reading. Visitor Studies 1(1), 101-112.

Tilden, F., 1957. Interpreting our heritage: Principles and practices for visitor services in parks, museums, and historic places. University of North Carolina Press: Chapel Hill, NC.

Tisdell, C., 1996. Ecotourism, economics, and the environment: observations from China. Journal of Travel Research 34(4), 11-19.

Tobii Pro 2016a. Tobii Pro Lab Analyzer Edition, Users's Manual. Tobii AB, Retrieved 21 August 2016 from http://www.tobiipro.com/siteassets/tobii-pro/usermanuals/Tobii-pro-glasses-analyzer-user-manual.pdf/?v=1.49.

Tobii Pro 2016b. Tobii Pro Glasses 2, Users's Manual. Tobii AB, Retrieved 21 August 2016 from http://www.tobiipro.com/siteassets/tobii-pro/user-manuals/tobiipro-glasses-2-user-manual.pdf/?v=1.1.3>.

Tobii Pro 2017. Tobii Pro Glasses 2 Live View Wireless. Retrieved 29 January 2017 from http://www.tobiipro.com/siteassets/tobii-pro/user-manuals/tobii-proglasses-2-user-manual.pdf/?v=1.1.3>.

Tómas, J., 1997. The Response of Two Icelandic Glaciers to Climatic Warming Computed with a Degree-Day Glacier Mass-Balance Model Coupled to a Dynamic Glacier Model. Journal of Glaciology 43(144), 321-327.

Tsai, M.J., Hou, H.T., Lai, M.L., Liu, W.Y., and Yang, F.Y., 2012. Visual Attention for Solving Multiple-Choice Science Problem: An Eye-Tracking Analysis. Computers \& Education 58(1), 375-385.

Uhmverfisstofunn, 2017a. Areas at Risk. Retrieved 15 May 12017 from http://www.ust.is/einstaklingar/nattura/svaedi-i-haettu/.

Uhmverfisstofunn, 2017b. Protected Areas. Retrieved 15 May 2017 from http://www.ust.is/the-environment-agency-of-iceland/protected-areas/\#Tab2.

Walter, P., 2009. Local knowledge and adult learning in environmental adult education: Community- based ecotourism in Southern Thailand. International Journal of lifelong education, 28(4), 513-532.

Weaver, D., 2001. Ecotourism as Mass Tourism: Contradiction or reality?. The Cornell Hotel and Restaurant Administration Quarterly 42(2), 104-112. 
Weston, C., Gandell, T., Beauchamp, J., McAlpine, L., Wiseman, C., and Beauchamp, C., 2001. Analyzing Interview Data: The Development and Evolution of a Coding System. Qualitative sociology 24(3), 381-400.

Wood, M.E., 1998. Meeting the global challenge of community participation in ecotourism: Case studies and lessons from Ecuador. Latin American and Caribbean Division, Nature Conservancy. 


\section{Appendix A: Respondent Demographics}

\begin{tabular}{|c|c|c|c|c|}
\hline Respondent & Gender & Age & Nationality & Study Site \\
\hline 1 & $\mathrm{~F}$ & 54 & UK & pingvellir \\
\hline 2 & $\mathrm{~F}$ & 30 & USA & Pingvellir \\
\hline 3 & $\mathrm{~F}$ & 22 & USA & Pingvellir \\
\hline 4 & $\mathrm{~F}$ & 22 & USA & Pingvellir \\
\hline 5 & $\mathrm{M}$ & 66 & USA & Pingvellir \\
\hline 6 & $\mathrm{~F}$ & 66 & USA & Pingvellir \\
\hline 7 & $\mathrm{~F}$ & 31 & Germany/Iceland Resident & Pingvellir \\
\hline 8 & $\mathrm{M}$ & 21 & Canada & Pingvellir \\
\hline 9 & $\mathrm{~F}$ & 68 & USA & Pingvellir \\
\hline 10 & $\mathrm{M}$ & 37 & USA & Pingvellir \\
\hline 11 & $\mathrm{~F}$ & 35 & From Czech, Living in USA & Pingvellir \\
\hline 12 & $\mathrm{M}$ & 35 & Canada & Pingvellir \\
\hline 13 & $\mathrm{M}$ & 24 & USA & Pingvellir \\
\hline 14 & F & 22 & USA & Pingvellir \\
\hline 15 & $\mathrm{~F}$ & 54 & Canada & Pingvellir \\
\hline 16 & $\mathrm{M}$ & 66 & USA & Pingvellir \\
\hline 17 & $\mathrm{~F}$ & 21 & USA & Pingvellir \\
\hline 18 & $\mathrm{M}$ & 62 & USA & Pingvellir \\
\hline 19 & $\mathrm{M}$ & 33 & USA & Pingvellir \\
\hline 20 & $\mathrm{M}$ & 34 & Germany & Pingvellir \\
\hline 21 & $\mathrm{~F}$ & 29 & Germany & Pingvellir \\
\hline 22 & $\mathrm{M}$ & 23 & Singapore & Pingvellir \\
\hline 23 & $\mathrm{~F}$ & 23 & Italy & Pingvellir \\
\hline 24 & $\mathrm{~F}$ & 38 & USA & Pingvellir \\
\hline 25 & $\mathrm{~F}$ & 39 & USA & Pingvellir \\
\hline 26 & $\mathrm{~F}$ & 24 & USA & Pingvellir \\
\hline 27 & F & 24 & USA & Pingvellir \\
\hline 28 & $\mathrm{~F}$ & 56 & USA & Pingvellir \\
\hline 29 & $\mathrm{M}$ & 59 & USA & Pingvellir \\
\hline 30 & $\mathrm{M}$ & 67 & UK & Pingvellir \\
\hline 31 & $\mathrm{M}$ & 70 & UK & Pingvellir \\
\hline 32 & F & 44 & USA & Pingvellir \\
\hline 33 & $\mathrm{M}$ & 54 & USA & Pingvellir \\
\hline 34 & $\mathrm{~F}$ & 46 & UK & bingvellir \\
\hline 35 & $\mathrm{~F}$ & 37 & Scotland & pingvellir \\
\hline 36 & $\mathrm{~F}$ & 38 & France & Sólheimajökull \\
\hline
\end{tabular}




\begin{tabular}{|c|c|c|c|c|}
\hline 37 & $\mathrm{~F}$ & 64 & USA & Sólheimajökull \\
\hline 38 & $\mathrm{~F}$ & & USA & Sólheimajökull \\
\hline 39 & M & 37 & USA & Sólheimajökull \\
\hline 40 & $\mathrm{~F}$ & 54 & Canada & Sólheimajökull \\
\hline 41 & M & 40 & France & Sólheimajökull \\
\hline 42 & $\mathrm{~F}$ & $40-50 \mathrm{~s}$ & USA & Sólheimajökull \\
\hline 43 & $\mathrm{M}$ & 52 & UK & Sólheimajökull \\
\hline 44 & $\mathrm{M}$ & 32 & Canada & Sólheimajökull \\
\hline 45 & $\mathrm{~F}$ & 74 & Canada & Sólheimajökull \\
\hline 46 & $\mathrm{~F}$ & 29 & Ireland & Sólheimajökull \\
\hline 47 & $\mathrm{M}$ & 74 & USA & Sólheimajökull \\
\hline 48 & $\mathrm{M}$ & 40 & Belgium & Sólheimajökull \\
\hline 49 & $\mathrm{M}$ & 73 & Ireland & Sólheimajökull \\
\hline 50 & $\mathrm{~F}$ & 45 & Ireland & Sólheimajökull \\
\hline 51 & $\mathrm{~F}$ & 70 & France & Sólheimajökull \\
\hline 52 & $\mathrm{~F}$ & 57 & Germany & Sólheimajökull \\
\hline 53 & M & 34 & USA & Sólheimajökull \\
\hline 54 & $\mathrm{~F}$ & 33 & USA & Sólheimajökull \\
\hline 55 & $\mathrm{~F}$ & 58 & Denmark & Sólheimajökull \\
\hline 56 & $\mathrm{M}$ & 69 & UK & Sólheimajökull \\
\hline 57 & $\mathrm{M}$ & 40 & UK & Sólheimajökull \\
\hline 58 & $\mathrm{~F}$ & 32 & USA & Sólheimajökull \\
\hline 59 & $\mathrm{~F}$ & 22 & USA & Sólheimajökull \\
\hline 60 & $\mathrm{~F}$ & 53 & USA & Sólheimajökull \\
\hline 61 & $\mathrm{M}$ & 33 & Canada & Sólheimajökull \\
\hline 62 & $\mathrm{M}$ & 32 & Spain & Sólheimajökull \\
\hline 63 & F & 27 & Portugal & Sólheimajökull \\
\hline 64 & $\mathrm{~F}$ & 66 & USA & Sólheimajökull \\
\hline 65 & $\mathrm{M}$ & 66 & USA & Sólheimajökull \\
\hline 66 & $\mathrm{M}$ & 30 & Switzerland & Sólheimajökull \\
\hline 67 & $\mathrm{M}$ & 61 & Netherlands & Sólheimajökull \\
\hline 68 & $\mathrm{M}$ & 62 & USA & Sólheimajökull \\
\hline 69 & F & 56 & Germany & Sólheimajökull \\
\hline 70 & $\mathrm{M}$ & 28 & USA & Sólheimajökull \\
\hline
\end{tabular}


Appendix B: Eye-Tracking Participant Demographics

\begin{tabular}{|l|l|l|l|l|}
\hline & & & & \\
Participant & Gender & Age & Nationality & \\
\hline 1 & F & 50 s/60s & UK & Singvellir \\
\hline 2 & F & 23 & USA & Pingvellir \\
\hline 3 & M & 34 & USA & Pingvellir \\
\hline 4 & M & 40 s/50s & USA & Pingvellir \\
\hline 5 & F & 23 & Canada & Pingvellir \\
\hline 6 & F & 35 & Canada & Pingvellir \\
\hline 7 & M & 37 & USA & Pingvellir \\
\hline 8 & M & 20 s & USA & Pingvellir \\
\hline 9 & M & 24 & USA & Pingvellir \\
\hline 10 & F & 30 & USA & Pingvellir \\
\hline 11 & M & 36 & Canada & Pingvellir \\
\hline 12 & M & 42 & USA & Dingvellir \\
\hline 13 & F & 30 & Northern Ireland & Pingvellir \\
\hline 14 & F & 31 & Northern Ireland & Dingvellir \\
\hline 15 & F & 57 & USA & Pingvellir \\
\hline 16 & F & 32 & Denmark & Sólheimajökull \\
\hline 17 & M & 44 & UK & Sólheimajökull \\
\hline 18 & M & 63 & Canada & Sólheimajökull \\
\hline 19 & M & 54 & USA & Sólheimajökull \\
\hline 20 & M & 36 & Germany & Sólheimajökull \\
\hline 21 & F & 32 & USA & Sólheimajökull \\
\hline 22 & M & 35 & Australia & Sólheimajökull \\
\hline 23 & F & 25 & Czech Republic & Sólheimajökull \\
\hline 24 & F & 29 & Germany & Sólheimajökull \\
\hline 25 & F & 25 & USA & Sólheimajökull \\
\hline 26 & M & 27 & USA & Sólheimajökull \\
\hline 27 & F & 45 & USA & Sólheimajökull \\
\hline 28 & M & 28 & Canada - Toronto & Sólheimajökull \\
\hline 29 & M & 57 & Netherlands & Sólheimajökull \\
\hline 30 & M & 30 & Belgium & Sólheimajökull \\
\hline & & & & \\
\hline
\end{tabular}




\section{Appendix C: Post-Visitatoin Assessment}

Age:___ Gender:___ Country of Origin:

Ocupation:

Educational Level:

Location:

Post-Assessment

For each of the following, circle the number which most accurately represents your experience here today. $5=$ strongly agree, $4=$ agree, $3=$ unsure, $2=$ disagree, $1=$ strongly disagree.

1. I learned new things about the culture of Iceland.

$$
\begin{array}{lllll}
1 & 2 & 3 & 4 & 5
\end{array}
$$

2. I learned new things about the geology of Iceland.

$$
\begin{array}{lllll}
1 & 2 & 3 & 4 & 5
\end{array}
$$

3. Information in signs throughout the park was easily understood.

$\begin{array}{lllll}1 & 2 & 3 & 4 & 5\end{array}$

4. The presence of trails and signs influenced my behavior within the park.

$\begin{array}{lllll}1 & 2 & 3 & 4 & 5\end{array}$

5. Trails, signs, and/or restricted areas are appropriate tools to decrease damage to the environment in ecotourism areas.

$\begin{array}{llllll}1 & 2 & 3 & 4 & 5\end{array}$

6. The designation of restricted areas negatively impacted my experience at this site.

$$
\begin{array}{lllll}
1 & 2 & 3 & 4 & 5
\end{array}
$$

Provide a short response for the following three questions.

7. Did you read the informational signs? If so, did you read them fully? Why or why not?

8. Why did you decide to visit this area today?

9. Did your experience meet your expectations? If not, what changes could be made to improve future visits? 
Appendix D: Pingvellir themes identified in eye-tracking trials

\begin{tabular}{|c|c|c|c|c|c|c|c|c|c|c|c|c|c|c|c|c|}
\hline \multicolumn{17}{|l|}{ Pingvellir Themes } \\
\hline \multicolumn{17}{|l|}{ Location Significance } \\
\hline Uncertain & & & & 1 & & 2 & & & & 2 & & 1 & & & 2 & 8 \\
\hline Understands & 1 & & & & 1 & & 1 & 1 & 1 & 1 & & 2 & 1 & & 1 & 10 \\
\hline \multicolumn{17}{|c|}{ Restricted Areas / Behavior } \\
\hline Acknowledge & & 2 & & 1 & & 1 & 1 & & & 1 & & 1 & & & 1 & 8 \\
\hline Minor Deviation & & & 1 & 1 & & 1 & & & & & & & 1 & & & 4 \\
\hline Major Deviation & & & & & & & & & & & & & & 1 & & 1 \\
\hline \multicolumn{17}{|l|}{ Location Experience } \\
\hline Positive & & 2 & 2 & & 4 & & 2 & & & & & 1 & 2 & & 1 & 14 \\
\hline Negative Due to Site & & & & 2 & & 2 & & & 2 & 3 & & & & & 1 & 10 \\
\hline Negative Due to MGMT & & 2 & 2 & 1 & 2 & 2 & & & 1 & 3 & & & & & 1 & 14 \\
\hline Uncertain of trails & & & 1 & 1 & 1 & 2 & & 1 & & & & 2 & & & & 8 \\
\hline \multicolumn{17}{|l|}{\begin{tabular}{|l|} 
Reads Signs \\
\end{tabular}} \\
\hline Yes, Fully & 2 & 1 & & 1 & 3 & 2 & 1 & 3 & 3 & 2 & & 5 & & 4 & 1 & 28 \\
\hline Yes, Partially & & 2 & 1 & 1 & 2 & 2 & 1 & 2 & 1 & 1 & & & & & 1 & 14 \\
\hline No & & & & 3 & & 1 & 3 & & & & 1 & 2 & 2 & & & 12 \\
\hline Directional - uncertain & & & & & 1 & 1 & & 1 & 1 & & & & & & & 4 \\
\hline Directional - understands & & & 2 & & & & 1 & 1 & & 1 & & 1 & & 1 & & 7 \\
\hline \multicolumn{17}{|l|}{ Human Impact } \\
\hline Cause & & & & & & & & & & & & 1 & & & & 1 \\
\hline Recognize & 2 & & & & & & & & & & & & & & & 2 \\
\hline Wants More Info & & & & & 2 & 1 & 1 & & 2 & 2 & & 1 & & & 1 & 10 \\
\hline
\end{tabular}


Appendix E: Sólheimajökull themes identified in eye-tracking trial

\begin{tabular}{|c|c|c|c|c|c|c|c|c|c|c|c|c|c|c|c|c|c|}
\hline \multicolumn{18}{|l|}{ Sólheimajökull Themes } \\
\hline \multicolumn{18}{|l|}{ Reads Signs } \\
\hline Yes, informational & & & & 1 & & & & & & & & & & & & & 1 \\
\hline yes, management & 1 & & 3 & & 1 & 1 & & 1 & 1 & 1 & 1 & 2 & 1 & 1 & & 2 & 16 \\
\hline No & & & & & & & & & & 1 & & & & & & & 1 \\
\hline Misinterprets Sign & & 1 & 1 & 1 & & & & & & & 1 & & & & & & 4 \\
\hline \multicolumn{18}{|l|}{ Restricted Areas / Behavior } \\
\hline Acknowledge \& Adhere & & & & & & 1 & 1 & & & & & & & 1 & & & 3 \\
\hline Acknowledge \& Deviate & 2 & 1 & 2 & 1 & 1 & & & 1 & 1 & 1 & 1 & 2 & 1 & & & 2 & 16 \\
\hline Don't Acknowledge \& Deviate & & & 1 & 1 & 2 & & & & & 1 & & & 1 & 1 & & & 7 \\
\hline Wants More Info & & & 1 & & & & 1 & & & 1 & 1 & & & & & & 4 \\
\hline Demonstrates Knowledge of Area & & 4 & 3 & & & & & & & & & & & & & & 7 \\
\hline
\end{tabular}

